\title{
Global ozone and air quality: a multi-model assessment of risks to human health and crops
}

K. Ellingsen ${ }^{1}$, M. Gauss ${ }^{1}$, R. Van Dingenen ${ }^{2}$, F. J. Dentener ${ }^{2}$, L. Emberson ${ }^{3}$, A. M. Fiore ${ }^{4}$, M. G. Schultz ${ }^{5}$, D. S. Stevenson ${ }^{6}$, M. R. Ashmore ${ }^{3}$, C. S. Atherton ${ }^{7}$, D. J. Bergmann ${ }^{7}$, I. Bey ${ }^{8}$, T. Butler ${ }^{9}$, J. Drevet $^{8}$, H. Eskes ${ }^{10}$, D. A. Hauglustaine ${ }^{11}$, I. S. A. Isaksen ${ }^{1}$, L. W. Horowitz ${ }^{4}$, M. Krol ${ }^{2,{ }^{*}}$, J. F. Lamarque ${ }^{12}$, M. G. Lawrence ${ }^{9}$, T. van Noije ${ }^{10}$, J. Pyle ${ }^{13}$, S. Rast ${ }^{5}$, J. Rodriguez ${ }^{14}$, N. Savage ${ }^{13,{ }^{* *}}$, S. Strahan ${ }^{14}$, K. Sudo ${ }^{15}$, S. Szopa ${ }^{11}$, and O. Wild ${ }^{15,{ }^{* \star *}}$

${ }^{1}$ University of Oslo, Department of Geosciences, Oslo, Norway

${ }^{2}$ Joint Research Centre, Institute for Environment and Sustainability, Ispra, Italy

${ }^{3}$ Stockholm Environment Institute, University of York, Heslington, UK

${ }^{4}$ NOAA GFDL, Princeton, NJ, USA

${ }^{5}$ Max Planck Institute for Meteorology, Hamburg, Germany

${ }^{6}$ University of Edinburgh, School of Geosciences, Edinburgh, UK

${ }^{7}$ Lawrence Livermore National Laboratory, Atmospheric Science Division, Livermore, USA

${ }^{8}$ Ecole Polytechnique Fédérale de Lausanne (EPFL), Switzerland

${ }^{9}$ Max Planck Institute for Chemistry, Mainz, Germany

${ }^{10}$ Royal Netherlands Meteorological Institute (KNMI), De Bilt, The Netherlands

${ }^{11}$ Laboratoire des Sciences du Climat et de l'Environnement, Gif-sur-Yvette, France

Multi-model assessment of ozone pollution indices

K. Ellingsen et al.

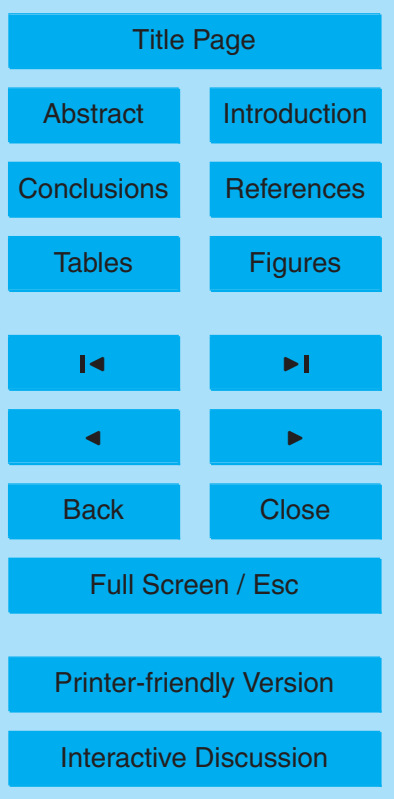


${ }^{12}$ National Center of Atmospheric Research, Atmospheric Chemistry Div., Boulder, CO, USA

${ }^{13}$ University of Cambridge, Centre of Atmospheric Science, UK

${ }^{14}$ Goddard Earth Science \& Technology Center (GEST), Maryland, Washington, DC, USA

${ }^{15}$ Frontier Research Center for Global Change, JAMSTEC, Yokohama, Japan

*now at: Wageningen University and Research Centre, Wageningen, the Netherlands

${ }^{* *}$ now at: Met Office, Exeter, UK

${ }^{* * *}$ now at: Dept. of Environmental Science, University of Lancaster, Lancaster, UK

Received: 22 November 2007 - Accepted: 20 December 2007 - Published:

Correspondence to: M. Gauss (michael.gauss@geo.uio.no)

8, 2163-2223, 2008

\section{Multi-model \\ assessment of ozone \\ pollution indices}

K. Ellingsen et al.

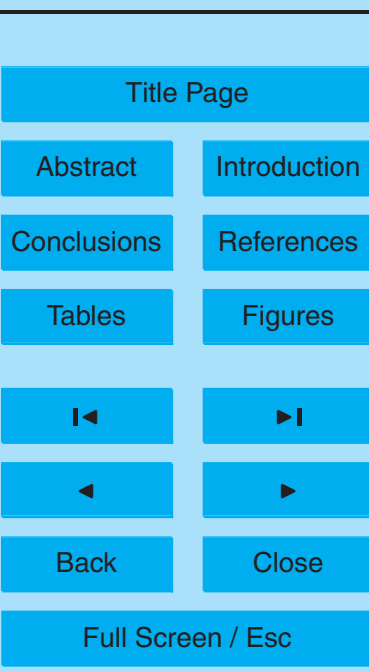

Printer-friendly Version

Interactive Discussion 


\section{Abstract}

Within ACCENT, a European Network of Excellence, eighteen atmospheric models from the U.S., Europe, and Japan calculated present (2000) and future (2030) concentrations of ozone at the Earth's surface with hourly temporal resolution. Comparison of model results with surface ozone measurements in 14 world regions indicates that levels and seasonality of surface ozone in North America and Europe are characterized well by global models, with annual average biases typically within $5-10 \mathrm{nmol} / \mathrm{mol}$. However, comparison with rather sparse observations over some regions suggest that most models overestimate annual ozone by $15-20 \mathrm{nmol} / \mathrm{mol}$ in some locations. Two in from the International Institute for Applied Systems Analysis (IIASA) and one from the Intergovernmental Panel on Climate Change Special Report on Emissions Scenarios (IPCC SRES) have been implemented in the models. This study focuses on changes in near-surface ozone and their effects on human health and vegetation. Different indices and air quality standards are used to characterise air quality.

15 We show that often the calculated changes in the different indices are closely interrelated. Indices using lower thresholds are more consistent between the models, and are recommended for global model analysis. Our analysis indicates that currently about two-thirds of the regions considered do not meet health air quality standards, whereas only $2-4$ regions remain below the threshold. Calculated air quality exceedances show moderate deterioration by 2030 if current emissions legislation is followed and slight improvements if current emissions reduction technology is used optimally. For the "business as usual" scenario severe air quality problems are predicted. We show that model simulations of air quality indices are particularly sensitive to how well ozone is represented, and improved accuracy is needed for future projections. Additional mea-

\section{Multi-model \\ assessment of ozone pollution indices}

K. Ellingsen et al.

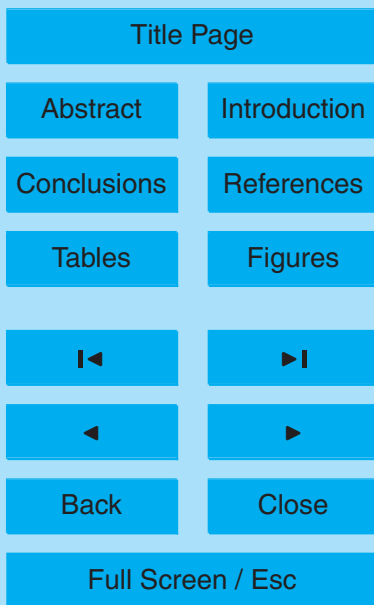

Printer-friendly Version

Interactive Discussion 


\section{Introduction}

Elevated ground level ozone is harmful to human health, crops and natural ecosystems. WHO (2003) reported that exposure to high ozone levels is linked to respiratory problems, such as asthma and inflammation of lung cells. Ozone may also aggra5 vate chronic illnesses such as emphysema and bronchitis and weaken the immune system. Eventually, ozone may cause permanent lung damage. Enhanced ozone reduces agricultural and commercial forest yields, and alters plant vulnerability to disease, pests, insects, other pollutants and harsh weather (USEPA, 1999; Aunan et al., 2000; Mauzerall and Wang, 2001; Emberson et al., 2003; Wang and Mauzerall, 2004).

10 Model studies indicate that much of the world's population and food production areas are currently exposed to damagingly high levels of ozone (West and Fiore, 2005). This situation could dramatically worsen over the coming century (Prather et al., 2003). In particular, due to Asia's rapid economic growth with associated consequences for increased environmental pollution, hemispheric transport of pollution, and rising back15 ground ozone levels, new areas are likely to be exposed to ozone pollution. Recent epidemiological studies have revealed damage to human health at typical present-day Northern Hemisphere background levels (i.e. $30-40 \mathrm{nmol} / \mathrm{mol}$ ) (WHO, 2003). Despite these major concerns, there has been little research focused on quantifying the risks of future exposure of the global biosphere to enhanced ozone levels (Ashmore, 2005) or on assessing potential health impacts on the global scale.

Ozone is formed when carbon monoxide (CO) and volatile organic compounds (VOC) are photo-oxidized in the presence of nitrogen oxides and sunlight, with ozone production occurring further downwind in the case of very high $\mathrm{NO}_{\mathrm{x}}$ emissions. Elevated surface ozone levels are therefore closely linked to emissions of these com25 pounds from anthropogenic activity, including biomass burning. The atmospheric lifetime of tropospheric ozone is long enough (1-2 weeks in summer to 1-2 months in winter) to be transported from a polluted region in one continent to another (e.g. Berntsen et al., 1999; Wild and Akimoto, 2001; Bey et al., 2001; Li et al., 2002; Auvray and

\section{Multi-model assessment of ozone pollution indices \\ K. Ellingsen et al.}

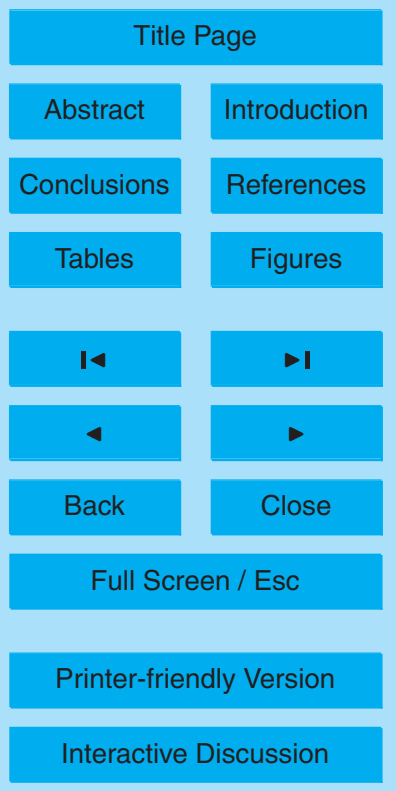

EGU 
Bey, 2005). Long-range transport can elevate the background level of ozone and add to locally or regionally produced ozone, sometimes leading to persistent exceedance of critical levels and air quality standards (e.g. Fiore et al., 2003). Regional efforts to control ozone increases through emission reductions of ozone precursors could be 5 counteracted by unregulated growth in other regions and affect background concentrations on a global scale (e.g. Derwent et al., 2004).

The number of peak-level ozone episodes is currently stable or decreasing in Europe and the U.S. (USEPA, 2005; EMEP, 2005a; Jonson et al., 2006). However, in 2003, a year of unusually high temperature conditions in western and central Europe during 10 summer, the EU threshold for informing the public $(90 \mathrm{nmol} / \mathrm{mol})$ was exceeded in 17 of the 27 reporting countries (EMEP, 2005a). France, Spain and Italy regularly reported hourly peak concentrations in excess of $120 \mathrm{nmol} / \mathrm{mol}$, levels which can cause serious health problems and damage to plants. The critical level for agricultural crops is exceeded regularly at most EMEP stations in central Europe, as is the critical level for 15 forests in larger parts of central and eastern Europe (EMEP, 2005b). There is evidence that Northern Hemispheric background ozone levels increased by almost a factor of two (about $20 \mathrm{nmol} / \mathrm{mol}$ ) since the 1950's (Staehelin et al., 1994), and there are indications that this increase is continuing, albeit at a slower rate (Simmonds et al., 2004). These trends are attributed to increases in global emissions of ozone precursors, in recent years mainly related to the rapid development in Asia (Akimoto, 2003). Future surface ozone levels will mainly be determined by the development of emission controls of ozone precursors. The implications of the IPCC SRES scenarios (Nakicenovic et al., 2000) on future surface ozone levels were discussed by Prather et al. (2003) indicating that surface ozone in the Northern Hemisphere could increase by about $255 \mathrm{nmol} / \mathrm{mol}$ by 2030 (the range across all the SRES scenarios was $2-7 \mathrm{nmol} / \mathrm{mol}$ ) and, under the most pessimistic scenarios, by over $20 \mathrm{nmol} / \mathrm{mol}$ in 2100 . Changes in climate and atmospheric composition are mediated by eco-systems, which themselves respond to changes in climate. Climate change (i.e. changes in atmospheric dynamics, water vapor, temperature) can alter tropospheric formation, distribution and deposition

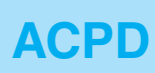

8, 2163-2223, 2008

\section{Multi-model \\ assessment of ozone pollution indices}

$\mathrm{K}$. Ellingsen et al.

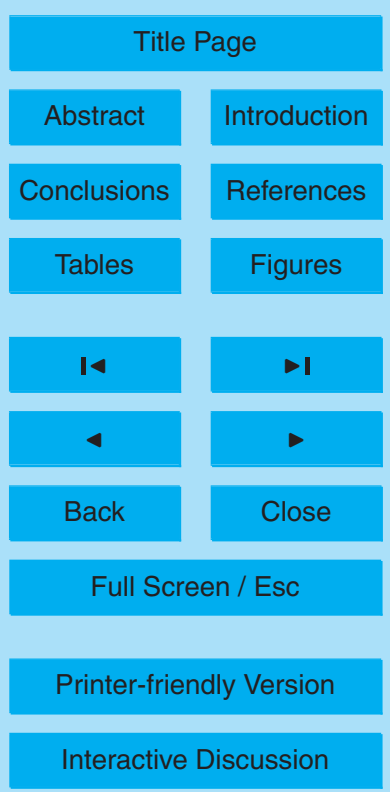

EGU 
of ozone (Sudo et al., 2003; Zeng and Pyle, 2003; Hauglustaine et al., 2005; Stevenson et al., 2005). Emission-climate feedbacks may result in changed emissions, such as increased biogenic VOC emissions in a warming atmosphere, and changes to the distribution and magnitude of lightning NOx emissions.

$5 \quad$ This study is part of a wider global model intercomparison called "ACCENT Photocomp" coordinated under Integrated Activity 3 of ACCENT ("Atmospheric Composition Change: the European NeTwork of excellence"). ACCENT Photocomp (Experiment 2) focused on the global atmospheric environment between 2000 and 2030 using 26 state-of-the-art global atmospheric chemistry models and three emission scenarios.

10 The present study uses a subset of 18 of these models that provided hourly surface ozone values. Several features of this intercomparison and further applications of model output have been published previously. An overview of model results was given by Dentener et al. (2006a). Stevenson et al. (2006) studied tropospheric ozone changes and the associated climate forcings and showed that the model ensemble mean for $\mathrm{O}_{3}$ generally agreed well with ozone observations in the free troposphere, with the mean values nearly always within a standard deviation of each other. Van Noije et al. (2006) compared modeled $\mathrm{NO}_{2}$ with three GOME retrieved $\mathrm{NO}_{2}$ columns: the range encompassed by models was often as large as that from the three retrievals. Dentener et al. (2006b) assessed present and future reactive sulphur and nitrogen deposition, Szopa et al. $(2006,2007)$ used the modeled ozone fields for a regional model study of future air quality in Europe, and Shindell et al. (2006) showed that modeled CO was systematically underestimated by all models when comparing with surface measurements and satellite retrievals. It has to be noted, however, that the models used specified emissions and that the underestimation primarily reflects uncertainties in the 25 emissions.

This publication focuses on the ability of global models to represent current surface ozone spatial and temporal distributions, the exceedance of ozone air quality indices and their possible development towards 2030 . We collected the hourly surface ozone concentrations from a large number of models. This exercise was the first time that

\section{Multi-model assessment of ozone pollution indices \\ K. Ellingsen et al.}

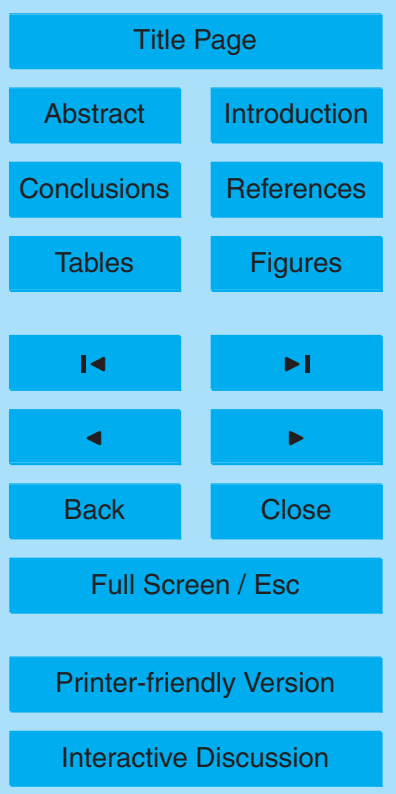

EGU 
hourly ozone from global models has been intercompared and used to evaluate global distributions of various ozone health- and vegetation-relevant air quality indices, based on the accumulation of hourly averaged concentrations above a given threshold (van Loon et al., 2007).

5 In the following section, we describe the models and the experimental setup. In Sect. 3, we discuss a wide range of currently used air quality standards currently used for vegetation (AOT40, SUM06, and W126) and human health [European and American standards, as well as the WHO recommended SOMO35] in the context of the ability of global models to represent them. In Sect. 4 results from the model calcula10 tions are given. In Sects. 4.1 and 4.2 annual mean surface ozone levels are discussed for all scenarios, and surface ozone levels for 2000 are compared to observations. We have compared model ensemble results for the 18 participating models, rather than individual model results, since in a previous study we showed that ensemble results were representative of the participating models, and that leaving out possible outliers 15 had little effect on the ensemble results (Stevenson et al., 2006). In Sect. 5, the results from the air quality standard studies are presented. We finish with a summary, conclusions, and an outlook.

\section{Experimental setup}

The key features of the 18 global atmospheric chemistry models that participated in this

study are described in Table 1. Twelve of these models are chemistry-transport models (CTMs) driven by meteorological analyses. Most models used analyses from ECMWF (European Centre for Medium-range Weather Forecasts). Six CTMs are driven by global circulation models (GCMs). The horizontal resolution ranges from $4^{\circ} \times 5^{\circ}$ to $1.8^{\circ} \times 1.8^{\circ}$, with one model using a two-way nested grid of $1^{\circ} \times 1^{\circ}$ over Europe, North

25 America and Asia. Models had between 19 and 60 vertical levels, and all extended well into the stratosphere (see Stevenson et al., 2006, Table A1).

Modelled surface ozone levels are compared to observations in Sect. 4. Comparison

\section{Multi-model assessment of ozone pollution indices}

K. Ellingsen et al.

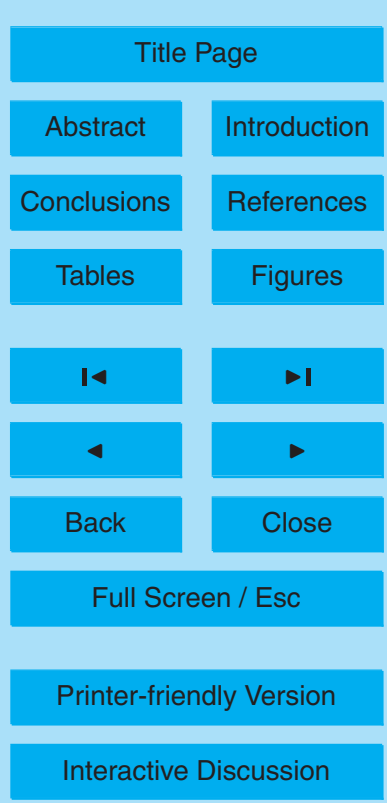


of free tropospheric ozone to ozone soundings by Stevenson et al. (2006) showed that the model ensemble mean agreed well with the observations, with the mean values nearly always within a standard deviation of each other.

Five different simulations were performed (Table 2). Table 3 gives a summary of 5 the simulations performed by the individual models, biogenic $\mathrm{C}_{5} \mathrm{H}_{8}$ and lightning $\mathrm{NOx}$ emissions used, and the height of the surface layer. S1 is the year 2000 base case simulation, whereas simulations S2, S3, and S4 used the same meteorology as S1 and three different 2030 emission scenarios. The CTMs used meteorological data from year 2000, the GCMs performed up to 9 year simulations with meteorological data for 10 the 1990s. The GCMs provided data for all years, the indices being calculated for each year separately and then averaged. Simulation S5 was performed by GCM-CTM models only, using the emission case of S2 and meteorology for the 2020s. All GCMs were configured as atmosphere-only models with prescribed sea-surface temperature (SSTs) and sea-ice distributions. Most GCMs used SSTs and sea-ice from a simulation of HadCM3 (Hadley Centre Coupled Model, version 3, Johns et al., 2003) forced by the IS92a scenario (Leggett et al., 1992) for the 2030 climate. Some GCMs used their own climate simulations. Spin-up lengths of at least 3 months were applied for all experiments.

Gridded anthropogenic emissions on $1^{\circ} \times 1^{\circ}$ of $\mathrm{NO}_{\mathrm{x}}, \mathrm{CO}, \mathrm{NMHC}, \mathrm{SO}_{2}$ and $\mathrm{NH}_{3}$ were 20 specified. In order to reduce the spin-up time, global $\mathrm{CH}_{4}$ mixing ratios were prescribed across the model domain (Table 4). The choice of $\mathrm{CH}_{4}$ values were based on two earlier studies (Dentener et al., 2005; Stevenson et al., 2005), together with IPCC recommendations for SRES A2 [IPCC, 2001, their Table II.2.2]. Emissions for the reference year 2000 and the future scenarios "Current Legislation" (CLE) and "Maximum

25 Feasible Reduction" (MFR) were based on recent inventories developed by the International Institute for Applied Systems Analysis (IIASA). The CLE scenario was based on legislation in place in the year 2001. We note here that recent emission legislation in India, adopting the EURO 3 standard for 4-wheel vehicles, could substantially reduce traffic emissions after 2010, but was not in place in time for this study. The global totals

\section{Multi-model assessment of ozone pollution indices}

K. Ellingsen et al.

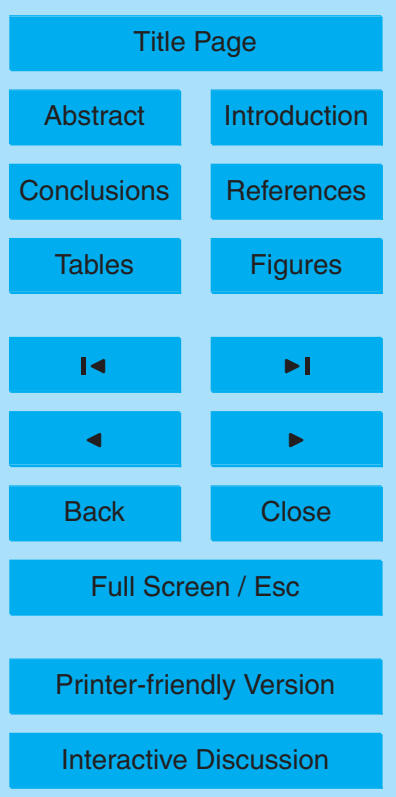

EGU 
of the future scenarios were distributed spatially according to EDGAR3.2 (Olivier et al., 2001) as described in (Dentener et al., 2005). To evaluate a high-emission case we also used the IPCC SRES A2 (A2) scenario (Nakicenovic et al., 2000). Monthly varying biomass burning $1^{\circ} \times 1^{\circ}$ gridded distributions were specified from GFED1.0 (van der

5 Werf et al., 2003), scaling $\mathrm{NO}_{\mathrm{x}}$ and VOC emissions to those of $\mathrm{CO}$. The values are averages for the period 1997-2002 and were used for all future scenarios as we felt that any other assumption would be highly speculative. Following AEROCOM (Dentener et al., 2006c) ecosystem dependent height distributions for biomass burning (boundaries at $0,0.1,0.5,1.0,2.0,3.0$ and $4.0 \mathrm{~km}$ ) and industrial emissions (height range 10 100-300 m) were recommended. However, some models added emissions to the lowest model layer only, whereas GMI/CCM3, GMI/DAO, GMI/GISS, IASB, TM4, TM5 and UIO_CTM2 used the recommendations for industrial emissions. These models as well as MOZ2-GFDL, LLNL-IMPACT and MOZECH also used the recommended height profile for biomass burning. The global totals of anthropogenic emissions (including biomass burning) for both the reference year and the future scenarios are reported in Table 4.

In addition, aircraft $\mathrm{NO}_{\mathrm{x}}$ emission totals of $0.8 \mathrm{TgN} /$ year for the year 2000 and $1.7 \mathrm{TgN}$ /year (all 2030 cases) and ANCAT or NASA [IPCC, 1999] distributions were recommended. Recommendations given on natural emissions are reported in Table 5. Lightning and soil $\mathrm{NO}_{\mathrm{x}}$ emissions were requested to be approximately 5 and $7 \mathrm{TgN} /$ year respectively. Modelers used values in the range of 3.7-7.0 Tg N/year for lightning and 5.5-8.0 Tg N/year for soil emissions. A total annual emission of $512 \mathrm{Tg}$ C/year isoprene (IPCC, 1999) was recommended; values in the range of 220$631 \mathrm{Tg}$ C/year were used. The actual isoprene and lightning $\mathrm{NO}_{\mathrm{x}}$ emissions used by each model are listed in Table 3.

A distribution of NMHC among individual species was recommended according to the specification given by (Prather et al., 2001, their Table 4.7). Species not included in the model were recommended to be either ignored or lumped into higher species.

As described before, most models provided hourly ozone concentrations for their

\section{Multi-model assessment of ozone pollution indices \\ K. Ellingsen et al.}

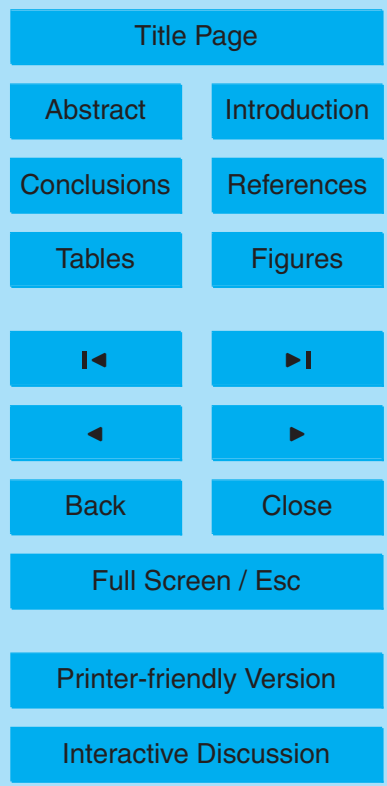

EGU 
respective surface layers. The thicknesses of these surface layers vary from model to model and are listed in Table 3. Using these results for comparison with measurements and for calculating global air quality indices is not straightforward. The best reference level for comparing model results with ozone measurements and for calculating the 5 exceedance of air quality indices would be at canopy height (typically 1-20 m, $1 \mathrm{~m}$ for crops, $20 \mathrm{~m}$ for forests) or at the height of human exposure (typically $2 \mathrm{~m}$ ). However, models report surface ozone averaged over the lowest model layer, which is usually well above the canopy. Since there can be significant vertical gradients due to dry deposition (ozone increasing with height), particularly under stable conditions, models 10 most likely overestimate the air quality indices. Also, we should realize that global scale models as used in this study can not resolve small scale ( $<100 \mathrm{~km}$ horizontal extent) peak episodes and are thus best suited to study the impact of background pollution levels. Where necessary we will indicate this important limitation in discussing the results of our study.

In Sect. 4 we focus on results calculated from the ensemble of individual models. Use of an ensemble should improve the robustness of model results as individual model errors, except systematic biases from emissions, are likely to cancel, whereas the real signal should be reinforced (e.g. Cubasch et al., 2001). The use of the full ensemble of models can be defended in this study since Stevenson et al. (2006) found that removing

outliers from a very similar model ensemble had little influence on the mean. We assume the entire ensemble to represent the most robust method to assess future levels of ozone and to quantitatively assess uncertainties. The standard deviation of the mean results gives an indication on the uncertainty in the ensemble results, while it does not account for systematic biases in all simulations (e.g. in emissions).

\section{ACPD}

8, 2163-2223, 2008

\section{Multi-model \\ assessment of ozone pollution indices}

K. Ellingsen et al.

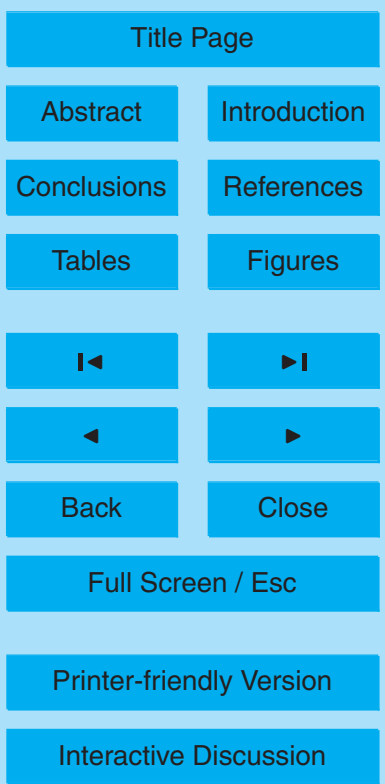




\section{Ozone air quality indices}

\subsection{Health indices}

In this section we discuss the health standards in use in the U.S. (USEPA, 1997) and Europe (WHO, 2000), as well as the recent WHO recommendation SOMO35 (Table 6).

5 All standards are based on hourly average mixing ratios to assess health risks from enhanced ozone levels. The European Ozone Directive 2002/3/EC requires EU Member States to alert the public when over 3 consecutive hours, ozone mixing ratios in excess of $240 \mu \mathrm{g} / \mathrm{m}^{3}(\sim 120 \mathrm{nmol} / \mathrm{mol})$ are measured. Similarly the public is to be informed when hourly average ozone mixing ratios exceed $180 \mu \mathrm{g} / \mathrm{m}^{3}(\sim 90 \mathrm{nmol} / \mathrm{mol})$.

10 As a long term objective, the European Ozone Directive has introduced a target value for the protection of human health, defined as a maximum daily eight-hour mean value of $120 \mu \mathrm{g} / \mathrm{m}^{3}(\sim 60 \mathrm{nmol} / \mathrm{mol})$ not to be exceeded on more than 25 days per year averaged over three years. In our global model assessment, for each model we evaluate the number of days per year that ozone exceeds the eight-hour mean $60 \mathrm{nmol} / \mathrm{mol}$ ("EU60") threshold.

U.S. standards have been governed by the Clean Air Act. The U.S. standard lowers the acceptable ozone level from the previously used $0.12 \mathrm{ppm}(=120 \mathrm{nmol} / \mathrm{mol})$ to $0.08 \mathrm{ppm}$ (USEPA, 1997). Whether or not the new standard is met, is determined by taking the fourth highest 8-h ozone levels of each year for three consecutive years and 20 averaging these three levels, equivalent to a maximum value of 3 exceedance days per year. In our study we will evaluate the number of days per year the eight-hour average limit value of $84 \mathrm{nmol} / \mathrm{mol}$ ("USEPA80") is exceeded. In our study, however, we generally only use one year to calculate the EU60 and USEPA80 indices.

The WHO/CLRTAP Task Force on Health Aspects of Air Pollution has recently rec-

ommended a different metric for assessment of policy options called SOMO35 (annual Sum Of daily maximum 8-h Means Over $35 \mathrm{nmol} / \mathrm{mol}$; see: http://www.unece.org/env/ documents/2004/eb/wg1/eb.air.wg1.2004.11.e.pdf). This proposed exposure parameter is defined as the average excess of daily maximum eight-hour means over a cut-off

\section{Multi-model assessment of ozone pollution indices \\ K. Ellingsen et al.}

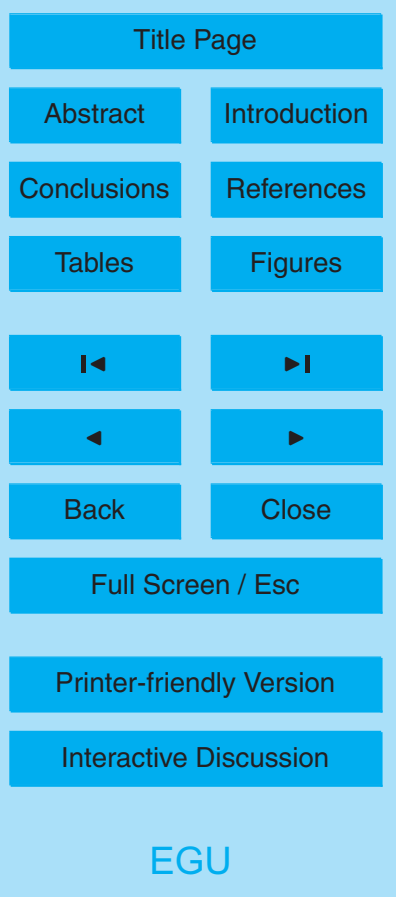


level of $35 \mathrm{nmol} / \mathrm{mol}\left(\sim 70 \mu \mathrm{g} / \mathrm{m}^{3}\right)$ calculated for all days in a year and is based on an expert re-evaluation of epidemiological studies.

The three health indices focus on different aspects of trends and fluctuations in ozone concentrations: SOMO35 accumulates ozone levels exceeding a "background" level 5 of $35 \mathrm{nmol} / \mathrm{mol}$. Consequently, this index will be sensitive to regional scale changes in background levels. On the other hand, the EU60 index, and even more so the USEPA80 index, are indicative of high peak levels in ozone concentrations, which are more difficult to capture with coarse resolution global models.

\subsection{Vegetation indices}

10 There has been considerable discussion over the last two decades in the U.S. and Europe as to how to summarize the effects on crop yield and forest growth caused by seasonal ozone exposure in a single index. The evidence collected indicates that ozone exposure indices should give greater weight to higher ozone concentrations. The AOT40 index (accumulated ozone concentration over a threshold of $40 \mathrm{ppb}$ ) (Fuhrer et al., 1997) is favored in Europe where analysis of experimental data for crops and young trees led to the adoption of this index by the UNECE (2004). In the U.S., the most widely used ozone vegetation indices include SUM06 (Mauzerall and Wang, 2001) and W126 (Lefohn and Runeckles, 1987; Lefohn et al., 1988); dose-response relationships based on these indices only exist for crops and not for trees. SUM06 considers only concentrations above $60 \mathrm{ppb}$ and then accumulates the total concentration. W126 uses a continuous rather than a step-weighting function, with a sigmoidal distribution, i.e. weights of $0.03,0.11,0.30,0.61$ and 0.84 at ozone volume mixing ratios of 40,50 , 60,70 , and 80 ppbv, respectively.

These three guidelines, AOT40, SUM06, and W126, which are summarized in Ta25 ble 7, are applied here at the global scale. Dose-response relationships can provide an indication of the relationship between ozone exposure and yield loss. Dose-response relationships based on the AOT40 index have been used to define values of char-

\section{Multi-model assessment of ozone pollution indices}

K. Ellingsen et al.

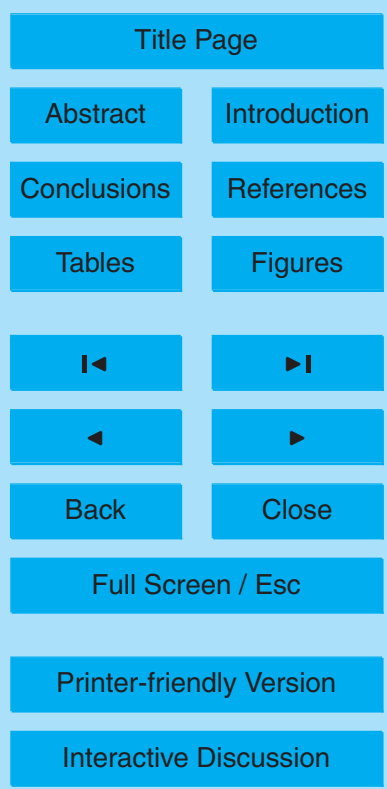


acterized ozone concentration below which damage would not be expected to occur (commonly known as the critical level concept) for regional scale risk assessments.

For this study, wheat was selected as the most relevant crop for risk assessment since it shows a strong sensitivity to ozone and is based on the most comprehen5 sive set of dose-response data. Implicitly we assume that the critical AOT40 level of $3 \times 10^{3} \mathrm{nmol} / \mathrm{molh}\left(\sim 6 \times 10^{3} \mu \mathrm{g} / \mathrm{m}^{3} \mathrm{~h}\right)$ for wheat would also "protect" other crops. This critical level is defined statistically and corresponds to a yield loss of $5 \%$. For forests, beech trees have shown a high sensitivity to ozone with AOT40 critical levels of $5 \times 10^{3} \mathrm{nmol} / \mathrm{mol} \mathrm{h}\left(10 \times 10^{3} \mu \mathrm{g} / \mathrm{m}^{3} \mathrm{~h}\right)$ having been established. To our knowl10 edge no equivalent critical level values have been defined for SUM06 or W126, but empirical (non-linear) exposure-yield response equations are available for $\mathrm{SUMO6}_{\text {day }}$ (=SUM06 accumulated over daylight hours (>50 W/m² PAR) only) and W126 [Wang and Mauzerall, 2004]. From these relations, we obtain values of $13.0 \times 10^{3} \mathrm{nmol} / \mathrm{mol} \mathrm{h}$ and $9.0 \times 10^{3} \mathrm{nmol} / \mathrm{mol} \mathrm{h}$ for SUM06 $6_{\text {day }}$ and W126, respectively corresponding to a $5 \%$ 15 yield loss. We note, however, that due to differences in analysis methods the critical

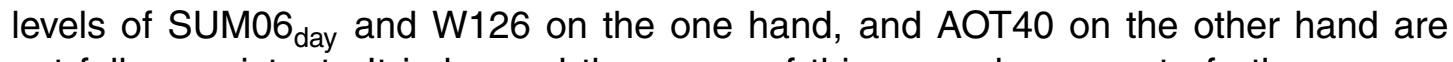
not fully consistent. It is beyond the scope of this paper however, to further assess these differences. For all three indices, hourly ozone concentrations, averaged over daylight only or over $24 \mathrm{~h}$, are accumulated over a defined growing season to obtain 20 the exposure index.

One important difficulty in applying these guidelines on a global scale is the definition of the length of the growing season. The AOT40 index should be applied over a threemonth period for agricultural crops and over a six month period for forest trees. This complicates the application of the index in multi-cropping areas in the tropics where a 25 number of different crops may be exposed sequentially to ozone episodes which could be causing damage throughout the year. In this work we assume a worst case scenario by estimating the maximum AOT40 index over a consecutive three or six month period. Only daytime ozone contributes to the AOT40 index. However, one important question is whether elevated ozone levels during night-time can damage plants. To investigate

\section{Multi-model assessment of ozone pollution indices}

K. Ellingsen et al.

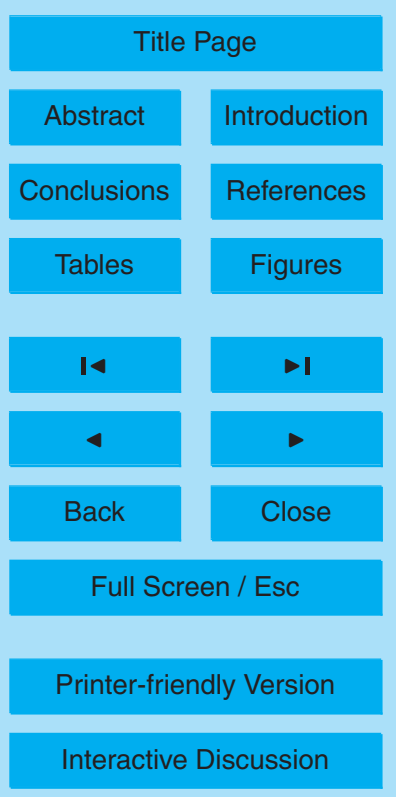

EGU 
the effect of exposure we calculate the SUM06 over both daylight-only and a 24-h period, while the W126 index is calculated over a 24-h period as defined in Table 7. We note that the indices discussed above have been shown to perform well in terms of explaining variations in growth and yield due to ozone damage, but only under chamber 5 conditions and on crop varieties specific to U.S. and European climates. We recognize that local meteorology will be important in determining crop variety, phenology and ozone dose all of which may modify crop and forest sensitivity to ozone exposures. As such, the global application of these indices can only provide a preliminary assessment of risk and thus the results shown in this study should only be considered as qualitative 10 (or semi-quantitative) indications of relative risk.

\section{Modeled ozone and comparisons with observations}

\subsection{Annual-mean surface ozone}

In order to assess inter-model agreement, Figures $1 \mathrm{a}$ and $1 \mathrm{~b}$ show the ensemble mean and standard deviation of annually averaged surface ozone for all the models participating in the experiment. Maximum annual mean values over large industrialized areas of North America, southern Europe, and Asia vary between 40 and $50 \mathrm{nmol} / \mathrm{mol}$, the \pm 1 standard deviation indicates a spread of ca. $20-30 \%$ among models. The Northern Hemisphere average is found to be $33.7 \pm 3.8 \mathrm{nmol} / \mathrm{mol}$, very close to the threshold concentration used to calculate SOMO35. The Southern Hemisphere average is $23.7 \pm 3.8 \mathrm{nmol} / \mathrm{mol}$, with background values of $15-25 \mathrm{nmol} / \mathrm{mol}$ and somewhat higher values $(35-40 \mathrm{nmol} / \mathrm{mol})$ in biomass burning areas in Africa and Latin America.

Figure 1c, d, and e display the changes of annual-mean surface ozone between 2000 and 2030 for the three different scenarios CLE (S2), MFR (S3), and SRES A2 (S4), respectively. The CLE scenario would stabilize ozone approximately at its 2000 levels by the year 2030 in large parts of North America, Europe and Asia. In areas where large increases in emissions from transport and power generation are expected to oc-

\section{Multi-model assessment of ozone pollution indices \\ K. Ellingsen et al.}

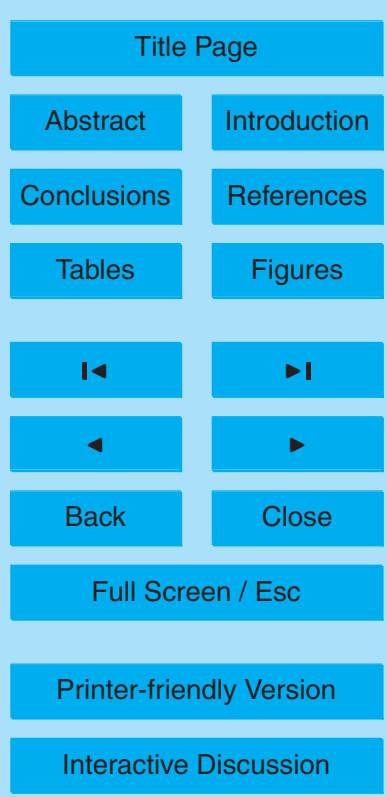


cur, surface ozone levels increases by about $5 \mathrm{nmol} / \mathrm{mol}$ over Southeast Asia and 10$15 \mathrm{nmol} / \mathrm{mol}$ over the Indian sub-continent. We note that this study assumed legislation in force by 2001 . More recent legislation in India could ameliorate these increases. Annual mean ozone increases of $2-4 \mathrm{nmol} / \mathrm{mol}$ in the tropical and mid-latitude Northern 5 Hemisphere $(\mathrm{NH})$ are related to the interaction of increasing concentrations of $\mathrm{CH}_{4}$ and worldwide increases of emissions of $\mathrm{NO}_{\mathrm{x}}$. The MFR scenario demonstrates the effects of maximal implementation and use of currently available technologies to reduce emissions of ozone precursors. Ozone surface levels are reduced by $5-10 \mathrm{nmol} / \mathrm{mol}$ in industrial areas, e.g. in large parts of North America, southern Europe, the Middle East 10 and southern Asia. As in earlier studies (Prather et al., 2003), the SRES A2 scenario leads to worldwide increases in surface ozone levels, with an average global increase of $4.3 \mathrm{nmol} / \mathrm{mol}$. The largest increases $(5-20 \mathrm{nmol} / \mathrm{mol})$ are seen in southern parts of the U.S., Latin America, Africa and southern Asia.

The change in tropospheric ozone abundances due to climate change was previ15 ously discussed in Stevenson et al. (2006). A slight decrease in tropospheric ozone was found in the lower troposphere, whereas increased stratospheric influx of ozone leads to an increase in the $\mathrm{NH}$ upper troposphere and reduced stratospheric influx leads to a decrease in the Southern Hemisphere $(\mathrm{SH})$ upper troposphere. For surface ozone, enhanced photochemical activity as a result of higher water vapour concentrations associated with climate change, leads to reduced ozone under clean background conditions, and to enhanced ozone under high NOx conditions in polluted regions (Murazaki and Hess, 2006). The effect of climate change (Fig. 1f) is however small, with reductions of $0.5-2 \mathrm{nmol} / \mathrm{mol}$ over the oceans, and less than $1 \mathrm{nmol} / \mathrm{mol}$ over remote continental surfaces. A small increase of $0.7 \mathrm{nmol} / \mathrm{mol}$ or less in surface ozone is found over polluted areas in the ensemble mean. Climate change affects ozone also through changes in the biosphere. For instance, elevated $\mathrm{CO}_{2}$ reduces stomatal conductance reducing the sink strength of the vegetated surface leading to reduced deposition and a build up of surface ozone concentrations (e.g. Harmens et al., 2007; Sitch et al., 2007). Similar effects may be induced by water and temperature stress. These processes

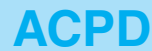

$8,2163-2223,2008$

\section{Multi-model assessment of ozone pollution indices}

K. Ellingsen et al.

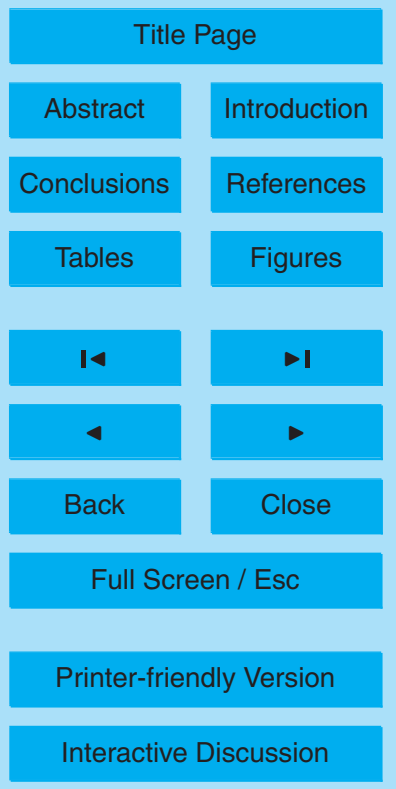

EGU 
were not considered in our study.

\subsection{Comparison to observed surface ozone levels}

We selected 13 polluted regions, and one clean region (Australia) representing clean $\mathrm{SH}$ background air (Table 8). Modeled surface ozone levels were averaged over the 5 land area of the respective regions, except for Australia. Figure 2 compares observed and model ensemble monthly mean surface ozone levels in nine selected regions (a subset of those listed in Table 8) for the year 2000. More detailed information about the measurement sites in these regions is given in the supplementary material (http://www. atmos-chem-phys-discuss.net/8/2163/2008/acpd-8-2163-2008-supplement.pdf). The variation in the model ensemble mean is illustrated including the model maximum and minimum values as well as standard deviations. The observations are averages over data from several observational sites. All measurement data are from UV absorption (on-line monitors), except the Carmichael et al. (2003) data (Table 8), which are derived from passive samplers. We note here that except for the U.S. and Europe a limited amount of measurements was available for comparison with model results.

The model ensemble mean represents the observed surface ozone levels in Europe and the U.S. rather well, often within one standard deviation. For the southwestern U.S. the mean model closely resembles the observations within one standard deviation, whereas the model ensemble overestimates the observations by $5-15 \mathrm{nmol} / \mathrm{mol}$ 20 in the southeastern U.S. The model ensemble represents the winter time and early spring values in the Great Lakes area very well, but overestimates summertime ozone by about $10 \mathrm{nmol} / \mathrm{mol}$. In the Central Mediterranean the model ensemble mean is less than $10 \mathrm{nmol} / \mathrm{mol}$ higher than the observed average and within one standard deviation of the observed monthly means, except for summer where surface ozone is overesti-

mated by about $15 \mathrm{nmol} / \mathrm{mol}$. For central Europe the mean model closely resembles the winter and early spring observations, whereas the summer and autumn observations are overestimated by about $6-13 \mathrm{nmol} / \mathrm{mol}$.

In the Middle East (not shown) ozone appears to be overestimated, but this sin2178
8, 2163-2223, 2008

\section{Multi-model assessment of ozone pollution indices}

K. Ellingsen et al.

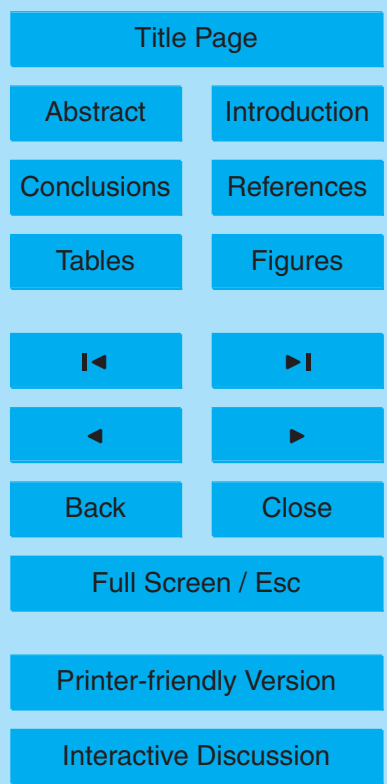

EGU 
gle high altitude site (Camkoru, Turkey, $1350 \mathrm{~m}$ a.s.l.) may not be representative of the model ensemble regional mean, which is dominated by high emissions related to oil-activity and biofuel burning. In central West Africa (not shown) and Southern Africa all models substantially overestimate ozone by $10 \mathrm{nmol} / \mathrm{mol}$ in the dry and up to

$520 \mathrm{nmol} / \mathrm{mol}$ in the wet season. For the Indian sub-continent (North and South India) the mean model ensemble is generally $15-20 \mathrm{nmol} / \mathrm{mol}$ higher than the observational average, and also none of the individual models is able to represent the low measurements. The discrepancy is particularly large during the winter monsoon season (February/March) with transport of clean ocean air to the measurement sites when the 10 models fail to reproduce the low observed ozone values Finally, the models represent $\mathrm{O}_{3}$ in northern China and southern Asia reasonably well.

We note here that there are very few coordinated networks monitoring ozone outside of Europe and North America, which is a situation that should be addressed as a matter of urgency, given the indications that future high episodes may occur over large parts of Asia and Africa.

\subsection{Do we understand the discrepancy between models and measurements?}

We showed in Sect. 4.2 that in North America, Europe and northern China computed monthly average surface ozone concentrations agree relatively well with measurements. However, in other regions such as Central West and Southern Africa, the Middle 20 East, North and South India the models overestimate the limited amount of measurements at our disposal. Several possible reasons may explain these discrepancies, such as an inaccurate description of emissions, meteorological and chemical processes in the models. Also, uncertainties in the measurements or their non-representativeness for the large-scale model gridboxes may be important. While there are a substantial 25 number of measurements used for North America and Europe, the number of measurements in other regions is rather small, and the quality control and how representative these measurements are is often questionable.

In our study we used estimates by IIASA for the year 2000 for anthropogenic $\mathrm{NO}_{\mathrm{x}}$,

\section{Multi-model assessment of ozone pollution indices}

K. Ellingsen et al.

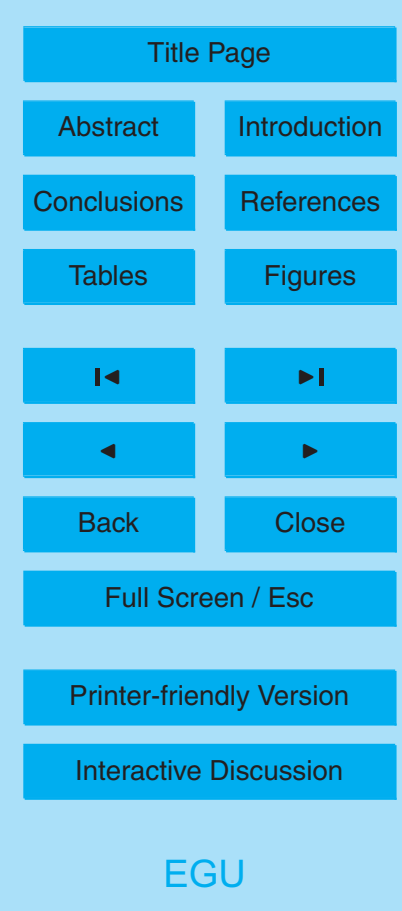


NMVOC and CO emissions (Cofala et al., 2005). Whereas a relatively good knowledge of emissions and technology levels is available in Europe and North America, the uncertainties are much larger in other continents, for instance in Asia differences of up to $40 \%$ are found in NOx between the inventory used here and the TRACE-P inventory 5 (Streets et al., 2003). An independent verification of $\mathrm{NO}_{\mathrm{x}}$ emissions is obtained from the analysis of GOME satellite data (van Noije et al., 2006) which indicates a factor of two too low $\mathrm{NO}_{2}$ columns over Southern Africa: use of larger $\mathrm{NO}$ emissions would probably further aggravate the discrepancies for ozone. In contrast over the biomass burning regions of Central Africa and South America $\mathrm{NO}_{2}$ columns seem to be up 10 to a factor of two too large. The open-fire $\mathrm{NO}_{\mathrm{x}}$ emissions were calculated from the GFED1.0 (van der Werf et al., 2003) database using the emission factors of (Andreae and Merlet, 2001). A recent revision of these emission factors revealed an approximately $30 \%$ lower emission factor for NO emissions from grass-land (savannah) fires (M.O. Andreae, personal communication). Sensitivity calculations with the TM4 model 15 (van Noije et al., 2006) show that the use of these lower emission factors would lead to lower surface ozone mixing ratios during the dry season by $10-15 \%$ and $6-10 \%$ in central West Africa and Southern Africa, respectively, explaining some of the discrepancy. Over India the $\mathrm{NO}_{2}$ columns were in relatively good agreement. The analysis of nitrate wet deposition reveals no systematic deviations over Africa and India (Dentener et al., 2006b), however a point-to-point comparison of depositions reveals a large spread and limited understanding of emission and deposition processes in Africa and India.

Most models are driven by meteorological parent models that are better tested and constrained in middle latitudes than in tropical regions. Also the degradation of the driving meteorology into lower resolution meteorology typically used in CTMs may cause 25 problems. For instance in India and Southeast Asia details of the monsoon circulation may be missed by the coarse resolution models. Turbulent and convective mixing play a relatively important role for mixing of air pollution in the tropics (Dentener et al., 1999; Jacob et al., 1997), but these mixing parameterizations have been hardly tested in low latitudes and their impacts on surface ozone are not easy to predict (Lawrence et al.,

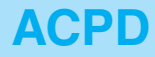

8, 2163-2223, 2008

\section{Multi-model \\ assessment of ozone pollution indices}

K. Ellingsen et al.

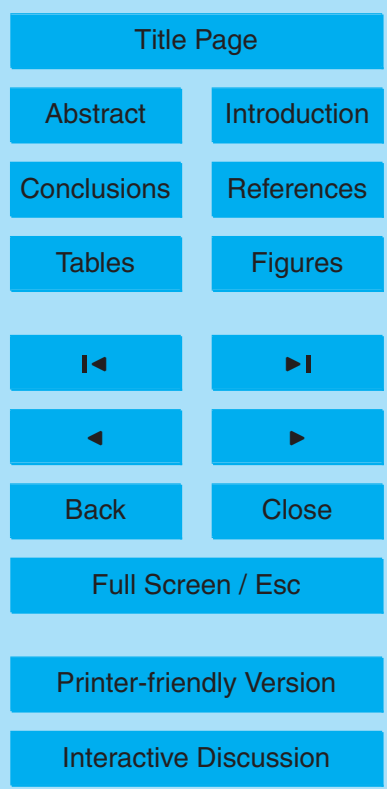

EGU 
2003; Doherty et al., 2005).

As we discussed before, an important source of error may be that most global models have a too coarse vertical resolution to represent the boundary layer vertical profiles at the observational sites. None of the models considered in this study applied param5 eterizations to derive surface (e.g. 1 or $20 \mathrm{~m}$ ) ozone although in theory this information should be included in the dry deposition parameterizations. Higher resolution models tend to produce less ozone from the same levels of precursor emissions due to less artificial redistribution of the emissions over the scales modelled (e.g. Esler, 2003; Wild and Prather, 2006). Thinner layers in the models also lead to larger ozone pre10 cursor concentrations and possibly to lower ozone due to titration effects. Especially at polluted places a significant component of the ozone concentration can be titrated by fresh NO emissions in the first 10-20 m above the ground. An indication for the importance of this effect is the improved agreement of "well mixed" afternoon ozone concentrations at sites in China and India, as demonstrated by analysis with the TM5 and FRSGC models. An important issue is that the air quality indices used in this study (Sect. 5) emphasize elevated concentrations during the daytime so that we expect that these can be better represented by models than indices taking into account all $24 \mathrm{~h}$ of a day, which are shown here.

Dry deposition schemes in models are generally based on the well-known Wesely 20 (1989) scheme. However, the overall effect on e.g. ozone removal and vertical ozone profiles in the model surface layer is strongly dependent on the assumptions on surface properties, boundary layer turbulence and surface layer thickness (Ganzeveld and Lelieveld, 1995). Indeed our preliminary analyses of ozone deposition distributions from the models suggest that the schemes generate quite variable deposition velocities over different terrains (Stevenson et al., 2006). As such, the recent development in Europe of dry deposition schemes that incorporate aspects of risk assessment through estimations of stomatal ozone dose should be continued, and the application of such schemes to regions across the globe encouraged (Emberson et al., 2001).

Stevenson et al. (2006) show that global tropospheric ozone production is rather

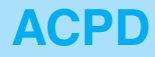

8, 2163-2223, 2008

\section{Multi-model \\ assessment of ozone pollution indices}

$\mathrm{K}$. Ellingsen et al.

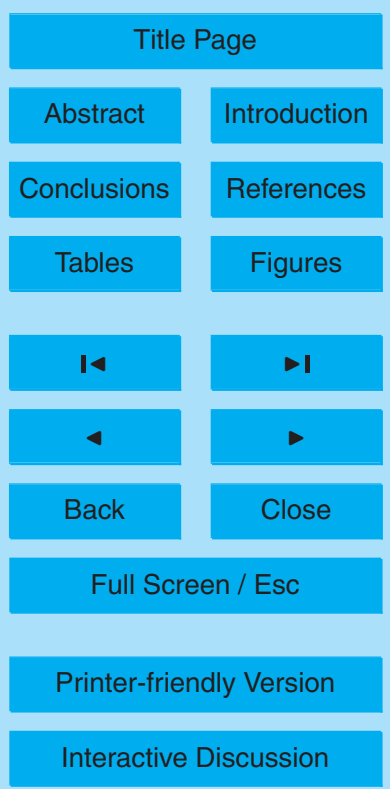

EGU 
similar between models. However, the description of heterogeneous chemistry is rather simplified in most models. Earlier studies (Dentener et al., 1996; Grassian, 2001; Jacob, 2000) suggested an important role for ozone destruction on mineral aerosol; however there is no consensus on the overall impact. The atmosphere in e.g. Southern

5 Africa, India and China during the dry season can be loaded with dust and pollution aerosol, and if heterogeneous chemistry is important these are the places where the impact is likely to be largest.

\section{Calculated ozone air quality indices}

The air quality indices defined in Tables 5 and 6 were calculated based on local time values for each model at each location, and then averaged over the models. We focus on the analysis of the air quality indices for 14 selected regions given in Table 8 . The regional values are calculated as land-only averages, taking the mean over continental ozone concentrations in the region and then calculating the index. These regions were chosen as a convolution of regions with high population density and expected high sur15 face ozone. The exception is Australia which represents clean Southern Hemispheric background conditions. In the following discussion we should bear in mind the sometimes large discrepancies of the mean model results with the sparse surface ozone measurements available. In these regions the model results should be considered in a more qualitative way, and the scenario results as indicative of a possible improvement

\subsection{Year 2000, base case}

\subsubsection{Health}

As shown in Fig. 3, elevated values for the SOMO35, EU60, and USEPA80 indices are found in, e.g., the southern U.S., southern Europe, the Middle East and Southeast Asia,

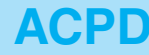

$8,2163-2223,2008$

\section{Multi-model assessment of ozone pollution indices}

K. Ellingsen et al.

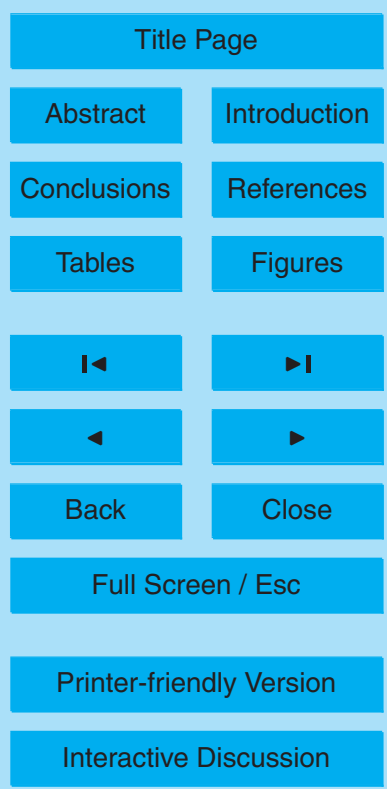

EGU 
exposing the population to health risk. Since the three indices are based on different thresholds, a different geographical pattern is obtained for the three indices. SOMO35 has high values in the southern parts of the U.S., southern Europe, central West Africa and southern parts of the Asian continent. The EU60 and USEPA80 indices typically 5 display high indices in the same areas but with larger variations and gradients. The EU60 ozone threshold is exceeded over larger areas than the USEPA80 threshold, e.g. the EU60 threshold for health risk is exceeded in central Europe, whereas the USEPA80 index is within recommended thresholds. The high values of USEPA80 seen in Fig. 3 (bottom panel) above Africa and South America are associated with biomass 10 burning.

As illustrated in Fig. 4a, the EU60 and USEPA80 threshold values are surpassed in most of the 14 selected regions. According to our ensemble model calculations, the EU60 threshold is exceeded in the southeastern U.S. during $105 \pm 58$ days and the USEPA80 threshold during $19 \pm 18$ days. Other regions at risk are southern India and the central Mediterranean. Of the 14 selected regions, only Australia has EU60 and USEPA80 indices below the recommended thresholds. The highest SOMO35 index of $6.8 \times 10^{3} \mathrm{nmol} / \mathrm{mol}$.days is found in the southeastern U.S. The Central Mediterranean, northern India, southern India and the Middle East all have values exceeding $5 \times 10^{3} \mathrm{nmol} / \mathrm{mol}$.days. Relatively high values are also found in the southwestern U.S., 20 southeastern Asia and northern China. Australia and Latin America are the only analyzed regions with SOMO35 indices lower than $2.5 \times 10^{3} \mathrm{nmol} / \mathrm{mol}$ days. In Fig. 5 we present a regression analysis of the regionally averaged data presented in Figure 4a. Interestingly we find a high correlation $\left(r^{2}=0.96\right)$ of SOMO35 and EU60 in the world regions; a similar relationship is found for SOMO35 and USEPA80, however statisti25 cally less significant $\left(r^{2}=0.55\right)$. The SOMO35 threshold level corresponding to EU60 is $2.4 \times 10^{3} \mathrm{nmol} / \mathrm{mol}$ days; the corresponding threshold of SOMO35 with USEPA80 would be $19.5 \times 10^{3} \mathrm{nmol} / \mathrm{mol}$ days. No limit values have been established for SOMO35 but in the following analysis we use a threshold of $2.4 \times 10^{3} \mathrm{nmol} / \mathrm{mol}$ days as consistent with both air quality indicators. We note here that these relationships probably hold only for

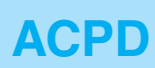

8, 2163-2223, 2008

\section{Multi-model \\ assessment of ozone pollution indices}

K. Ellingsen et al.

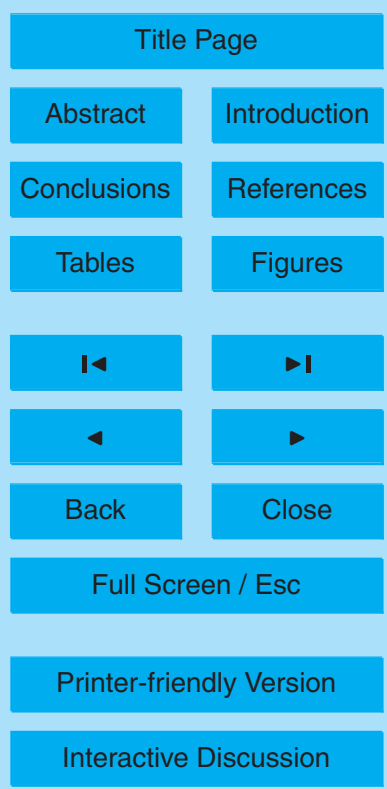

EGU 
the integrated ozone values in polluted regions as used in this study. These regions are exposed to background ozone levels around $35 \mathrm{nmol} / \mathrm{mol}$ with pollution episodes above this level.

As most of the 14 regions exceed the threshold values of EU60 (25 days), USEPA80 5 (3 days) or SOMO35 $\left(2.4 \times 10^{3} \mathrm{nmol} / \mathrm{mol}\right.$ days $)$, we explored the extent to which these regions would comply if the regulations would be less stringent. Figure $4 a$ also indicates the regions where threshold values are exceeded by less than a factor of 2 (i.e. for EU60 indices $>50$ days, for USEPA80 indices $>6$ days, and for SOMO35 indices $>4.8 \times 10^{3} \mathrm{nmol} / \mathrm{mol}$ days). Still most regions would not comply with the standards; whereas only the American Great Lakes, central East Africa and central Europe would comply with EU60. It is difficult to assess what the consequences for the air quality indicators would be if indeed the models do systematically overestimate ozone as indicated in Sect. 4.2 and 4.3, since the limited amount of measurements precludes the analysis of the underlying reasons for the overestimates. As a first order analysis we estimate that for instance for the Mediterranean a correction of an annual average bias of $10 \mathrm{nmol} / \mathrm{mol}$ would bring almost all model calculated ozone air quality to compliance with SOMO35, EU60 and EPA80. In contrast for northern India, almost all models still indicate exceedance of ozone above the thresholds after correcting their annual average by $10 \mathrm{nmol} / \mathrm{mol}$.

We further note that the standard deviations for the computed EU60 indices and especially USEPA80 indices are much larger than for SOMO35 indices. This reflects the higher consistency amongst the models in prediction of average ozone levels exceeding background values and the larger uncertainty connected with prediction of peak ozone levels. Therefore SOMO35 indices seem to be the most robust indicator for ozone air quality derived from our ensemble of global model calculations. Changes in the three air quality indices over the 14 selected regions for the future cases S2, S3, and S4 will be discussed in Sect. 5.2.

\section{Multi-model assessment of ozone pollution indices}

K. Ellingsen et al.

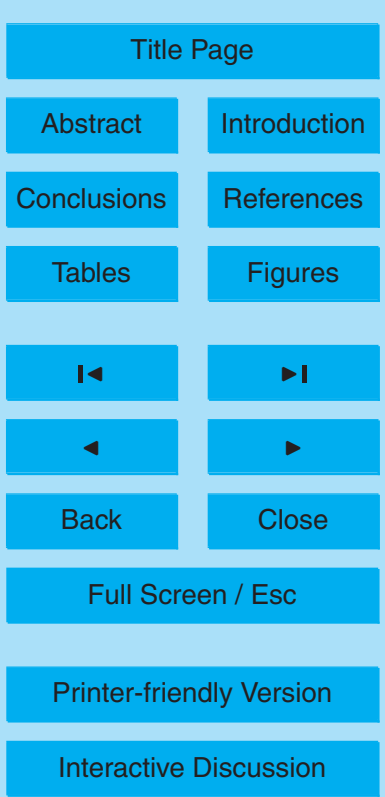

EGU 


\subsubsection{Vegetation}

Figure 6 shows the model ensemble mean AOT40 for the baseline scenario (S1) considering a growing season of 3 months $($ AOT40 $3 \mathrm{~m}$ ) for crops and 6 months $\left(A O T 40_{6 \mathrm{~m}}\right)$ for forests, respectively. We further show SUM06 accumulated both over $524 \mathrm{~h}\left(\mathrm{SUMO6}_{24 \mathrm{~h}}\right)$ and daylight hours only (SUM06 day $)$, and W126 indices. Figure 7a displays the ensemble mean weighted averages and standard deviations of these indices for the 14 selected regions.

Similarly to the health indices, 'hot spots' with elevated values in the vegetation indices are found in industrialized areas of Europe, the U.S. and Asia as well as 10 in biomass burning areas in Latin America and Africa. The 5 vegetation indices in the 14 selected regions show high mutual correlation coefficients, between $r^{2}=0.85$

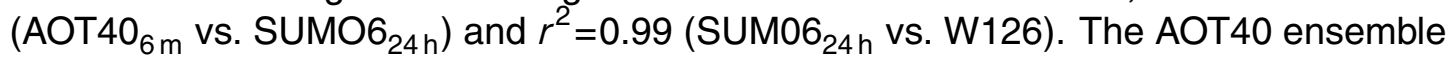
means show lower standard deviations than SUM06 and W126, confirming the higher consistency amongst the models when predicting exceedance of concentrations closer 15 to background ozone levels compared to exceedance of high ozone levels.

$\mathrm{AOT}_{40} \mathrm{~m}$ indices larger than $20 \times 10^{3} \mathrm{nmol} / \mathrm{molh}$ are predicted over the central Mediterranean, the southeastern U.S., the Middle East and northern India. The lowest values are found over Australia and Latin America. Only in Australia AOT $40_{3 \mathrm{~m}}$ is below the critical level (the level below which adverse effects would not be expected 20 to occur, i.e. $3 \times 10^{3} \mathrm{nmol} / \mathrm{mol}$ h for agricultural crop). When we calculate the same AOT $40_{3 \mathrm{~m}}$ solely based on the set of observations given in Sect. 4.2, we calculate for central Europe and the central Mediterranean AOT40 of $9.4 \pm 2.8 \times 10^{3} \mathrm{nmol} / \mathrm{mol} \mathrm{h}$ and $13.0 \pm 6.5 \times 10^{3} \mathrm{nmol} / \mathrm{mol} \mathrm{h}$, respectively. The corresponding model ensemble values of $10.3 \pm 5.9 \times 10^{3} \mathrm{nmol} / \mathrm{mol} \mathrm{h}$ are consistent for central Europe. However, the computed $23.2 \pm 10.7 \times 10^{3} \mathrm{nmol} / \mathrm{mol} \mathrm{h}$ for the central Mediterranean is a factor of two higher, showing the large sensitivity of AOT40 to accurate calculations of ozone around $40 \mathrm{nmol} / \mathrm{mol}$. A further factor in explaining the discrepancies over the Mediterranean area may be lack of model resolution to resolve the difference of ozone over land and sea as we

\section{Multi-model \\ assessment of ozone pollution indices}

K. Ellingsen et al.

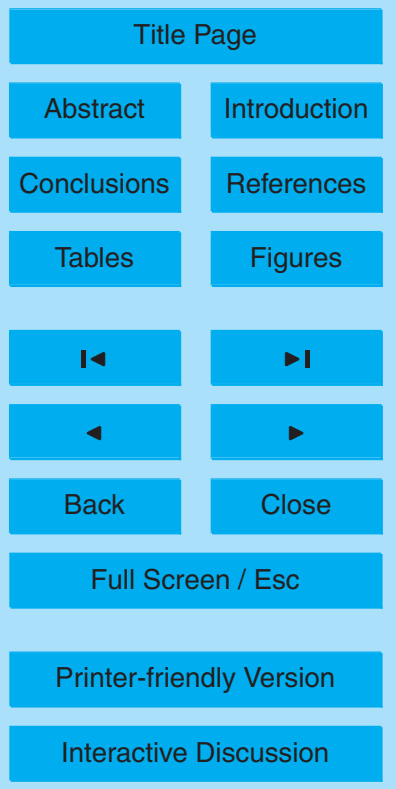


average out the highly different mixing depths and deposition velocities between ocean and land.

We calculate $\mathrm{AOT}_{40} \mathrm{~m}$ (forests, 6 months) of more than $30 \times 10^{3} \mathrm{nmol} / \mathrm{mol} \mathrm{h}$ for the southwestern and southeastern U.S., the central Mediterranean, and the Middle

5 East; i.e. 6 times the exceedance of the critical level for reduction of forest growth $\left(5 \times 10^{3} \mathrm{nmol} / \mathrm{mol} \mathrm{h}\right)$. Of the 14 regions, only Australia has $\mathrm{AOT} 40_{6 \mathrm{~m}}$ lower than this threshold. The calculated SUMO6 ${ }_{24 \mathrm{~h}}$ and $\mathrm{SUMO6}_{\text {day }}$ are very similar with in general differences less than $10 \%$, and exceed $50 \times 10^{3} \mathrm{nmol} / \mathrm{mol} \mathrm{h}$ over the southeastern U.S., the central Mediterranean, northern India and the Middle East and have the lowest 10 value over Australia. As opposed to AOT40 and SUM06, the W126 index uses a continuous weighting function. However, W126 correlates very well with $A O T 40_{3 m}$ and SUM06 $_{\text {day }}$. The highest W126 values are found in the central Mediterranean, the southeastern U.S., India and the Middle East (exceeding $40 \times 10^{3} \mathrm{nmol} / \mathrm{mol} \mathrm{h}$ ) whereas the lowest values are found over Australia, Latin America and central Europe. As shown 15 in Sect. 3.2, limit levels of $13 \times 10^{3} \mathrm{nmol} / \mathrm{mol} \mathrm{h}$ for SUM06 day and $9 \times 10^{3} \mathrm{nmol} / \mathrm{mol} \mathrm{h}$ for W126 would correspond to a $5 \%$ yield loss.

For the reference case $\mathrm{S} 1$ in all regions except Australia these limits are exceeded, indicating the potential for significant crop losses due to ozone pollution.

\subsection{Year 2030, future scenarios}

\section{$20 \quad 5.2 .1$ Health}

The current legislation scenario (CLE) implies a general increase in the computed health-based pollution indices, with highest increases in the $\mathrm{NH}$ and in particular over the Indian sub-continent. Regional average changes are presented for the 14 selected regions in Fig. 4b. The SOMO35 index increases by $23 \%$ in the $\mathrm{NH}$ and by $15 \%$ in the $\mathrm{SH}$. We note that previous numbers are surface area averaged, and not weighted with population. The increase over India is $60 \%$ or approximately 3400 additional

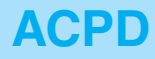

$8,2163-2223,2008$

\section{Multi-model assessment of ozone pollution indices}

K. Ellingsen et al.

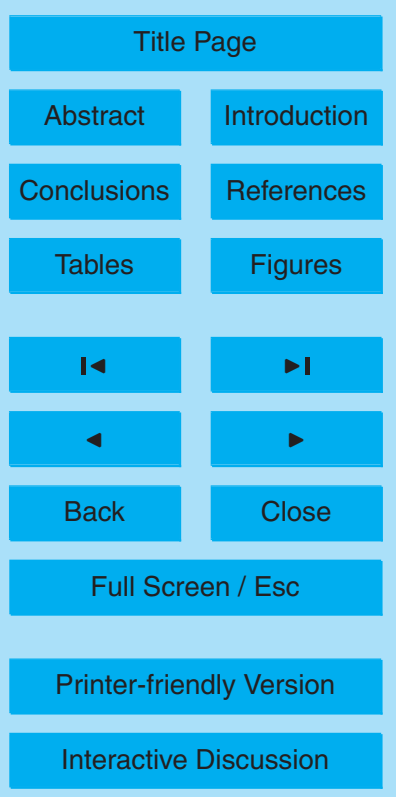

EGU 
$\mathrm{nmol} / \mathrm{mol}$.days.

The increase of background ozone (as indicated by the SOMO35 index) is in general paired with increased peak ozone values (indicated by EU60 and USEPA80 indices). Averaged over the continental $\mathrm{NH}$, the EU60 index increases by $47 \%$ while the $\mathrm{SH}$

5 is subject to a smaller change of $12 \%$. The change is not uniformly distributed: we find the largest increase in $\mathbf{2 0 3 0}$ over India with approximately 100 additional days of exceedance, a doubling compared to $S 1$. Opposed to the general trend, there is a small decrease in EU60 over the Central Mediterranean $(-3 \%)$ and central Europe $(-15 \%)$ bringing Central European values below the threshold for health risk.

10 For USEPA80, we also find large increases over the Indian sub-continent, amounting to $320 \%$ and $400 \%$ over northern India and southern India, respectively, giving totals of 34 and 27 days of excess. European values are lowered, with 9 days of exceedance for the Central Mediterranean and central European values below the threshold for health risk.

15 Europe is an interesting policy relevant case: according to the conventional EU60 and USEPA80 indices, air quality is improved under the CLE scenario, due to reductions in domestic anthropogenic emissions. However, the European SOMO35 index increases, reflecting a continued rise in European background ozone values due to the increased global emissions of ozone precursors and intercontinental transport. Similarly, a rise in surface ozone in the U.S. despite domestic reductions was calculated by Fiore et al. (2002) for the year 2030 based on the IPCC A1 and B1 scenarios. This is contradictory to the general SOMO35 - EU60 correlation established before, showing that the change of indices is not necessarily coupled in all cases. Following our previous analysis, in 2030 CLE the " $2 x$ threshold" is exceeded in 12, 11, and 11 regions for SOMO35, EU60, and USEPA80, respectively. The relatively "clean" regions are mostly limited to the extra-tropics, where photochemistry is less intense. Future work should consider the potential discrepancy of models with measurements.

The maximum feasible reduction scenario (MFR) leads to a worldwide improvement of ozone air pollution. Regional averages of change are presented in Fig. 4c, and

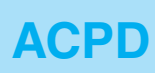

8, 2163-2223, 2008

\section{Multi-model \\ assessment of ozone pollution indices}

K. Ellingsen et al.

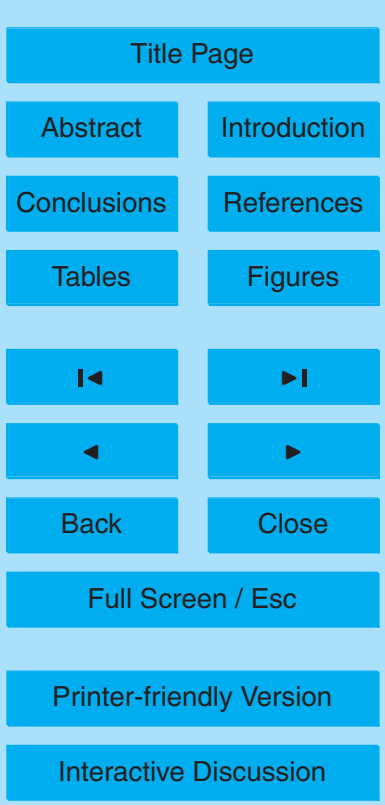

EGU 
the global distribution is shown in Fig. $8 \mathrm{a}$ and $\mathrm{c}$. The largest reductions appear in polluted areas, i.e. southern parts of the U.S., southern Europe, the Middle East, India and S.E. Asia in response to reduced anthropogenic emissions of ozone precursors. Under the MFR scenario ozone is below or close to the respective thresholds. We note,

5 however, that in our study we did not assume that biomass burning emissions would decrease. A reduction of emissions as indicated by the MFR scenario has a positive effect on future surface ozone levels; the general compliance to all three health indices clearly demonstrates the capacity for this emission scenario to abate ozone pollution and thereby reduce undesirable health effects.

10 The SRES A2 scenario raises the health-based ozone pollution indices worldwide, especially over industrialized regions (Figs. 4d, 8b, and d). The area with elevated values extends further into northern Europe, northern Asia and Africa. Both background ozone and peak ozone episodes increase, but with a relatively stronger increase in peak ozone episodes, giving continental $\mathrm{NH}$ values of $5.6 \times 10^{3} \mathrm{nmol} / \mathrm{mol}$ days for the 15 SOMO35 index (75\% increase), 81 days for the EU60 index (153\% increase) and 16 days for the USEPA80 index (300\% increase). In the Indian subcontinent we find air quality indices higher than anywhere else in the world, but as we noted before, models tend to overestimate ozone in that region. Very high values are also found over North America, e.g. $9.4 \times 10^{3} \mathrm{nmol} / \mathrm{mol}$ days (SOMO35), 164 days of exceedance (EU60) and 48 days of exceedance (USEPA80) over the southeastern U.S. Also in the central Mediterranean, the Middle East and southeast Asia we find high values, i.e. SOMO35 index of approximately $8 \times 10^{3} \mathrm{nmol} / \mathrm{mol}$ days, the EU60 threshold exceeded on approximately 100 days and USEPA80 threshold values being exceeded on more than 30 days.

25 In particular, the increase in number of days exceeding $80 \mathrm{nmol} / \mathrm{mol}$ (USEPA80) over the Indian sub-continent and the Middle East is prominent. The large increase in the number of days exceeding $60 \mathrm{nmol} / \mathrm{mol}$ over Australia is probably due to transport of pollution from southern Asia. The increase in the SOMO35 index is largest over Latin America, the African regions and India. The EU60 and USEPA80 thresholds for health

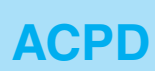

$8,2163-2223,2008$

\section{Multi-model \\ assessment of ozone pollution indices}

K. Ellingsen et al.

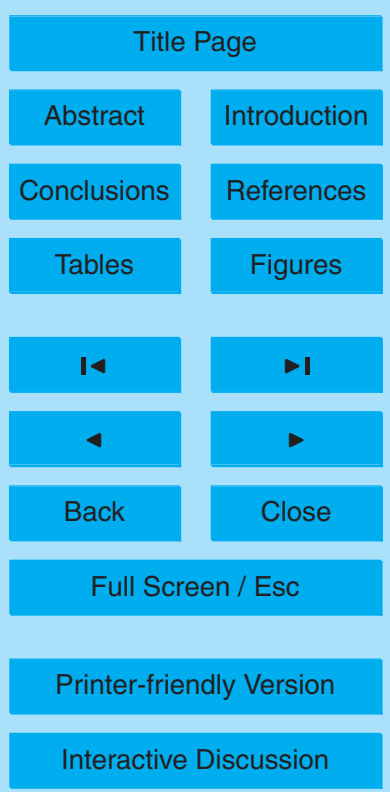


risk are largely surpassed in all regions and on a global average, demonstrating an alarming development if emissions rise as anticipated in the A2 scenario. West et al. $(2006,2007)$ have related elevated ozone concentrations until 2030 to global premature mortalities for the case of possible methane mitigation and the IIASA emission 5 scenarios.

\subsubsection{Vegetation}

Figure $7 \mathrm{~b}, \mathrm{c}$, and $\mathrm{d}$ show the changes in exceedance of all vegetation air quality indices for CLE, MFR and A2, respectively, for the 14 selected regions. Figure 9 illustrates the geographical distributions of the change (shown are $\mathrm{AOT}_{40} \mathrm{O}_{3 \mathrm{~m}}$ and $\mathrm{SUMO}_{\text {day }}$ for crops, $10 \mathrm{AOT}_{40} \mathrm{~m}_{\mathrm{m}}$ for forests) for MFR and SRES A2, i.e. the low and the high emission cases, contrasting what is possible with today's technology and what is estimated to happen without further regulation.

As expected, CLE leads to a general increase in the exceedance of vegetation indices in the year 2030, and according to all indicators in all regions, except Aus15 tralia, crop losses larger than $5 \%$ occur (i.e. larger than $3.0 \times 10^{3}, 9.0 \times 10^{3}$, and $12.0 \times 10^{3} \mathrm{nmol} / \mathrm{mol} \mathrm{h}$ for AOT40, SUMO6 and W126).

The increase over the $\mathrm{NH}$ for the vegetation indices ranges between $21-38 \%$. On the Indian subcontinent, where no restrictive measures on emissions of ozone precursors were assumed to be implemented, the AOT40 indices increase 50-63\%, whereas

the SUM06 and W126 indices increase by 75-97\%. This indicates a larger increase in episodic peak levels compared to the increase in ozone background levels in this region. Large increases are also found in S.E. Asia where increases in emissions from transport and power generation are anticipated, i.e. $20-30 \%$ for AOT40 and $30-40 \%$ for SUM06 and W126.

25 Increases of the same order are also found over the African regions due to increased biofuel use. Despite the implementation of policies for air quality improvement, the selected U.S. regions show an increase between 20 and 30\% for SUM06 and W126 (i.e. the U.S. favored indices) and between 12 and $16 \%$ for AOT40. In contrast, currently 2189

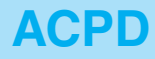

$8,2163-2223,2008$

\section{Multi-model assessment of ozone pollution indices}

K. Ellingsen et al.

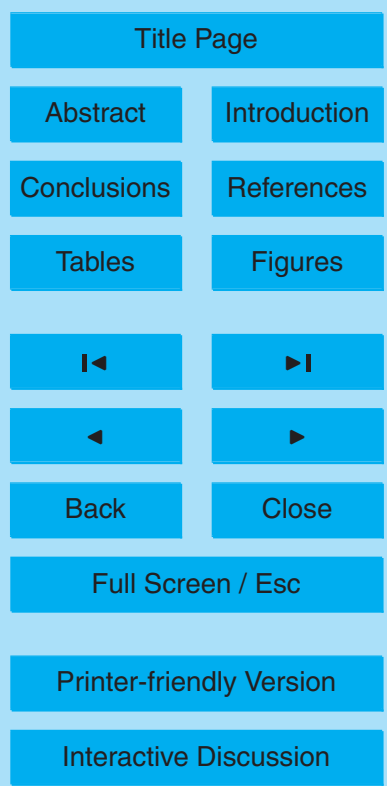

EGU 
implemented European legislation stabilizes or slightly reduces the vegetation indices over Europe by 2030. In particular, the central Mediterranean is the only region (out of the 14) where all indices show a decreasing trend. In agreement with the findings for the health air quality indices, we find larger reductions over Europe for indices based 5 on higher threshold values (SUM06 and W126) than for the lower threshold AOT40 indices.

The MFR scenario leads to a worldwide decrease of the vegetation indices. The reductions appear in polluted areas with the largest reductions in southern parts of the U.S., Europe, the Middle East, northern China and Southeast Asia, i.e. AOT40 de10 crease by $50-70 \%$, SUM06 and W126 by $70-200 \%$ in these regions. Nevertheless, in most regions the MFR emission reductions do not bring AOT40 values below the critical level for agricultural crops $\left(3 \times 10^{3} \mathrm{nmol} / \mathrm{mol} \mathrm{h}\right)$ or forests $\left(5 \times 10^{3} \mathrm{nmol} / \mathrm{mol} \mathrm{h}\right)$, confirmed by the results of SUM06 and W126.

The SRES A2 scenario leads to large worldwide increases in the vegetation in15 dices and in particular over industrialized regions. The largest increases are found in Southeast Asia and India where AOT40 increases by $80-100 \%$, SUM06 and W126 by $90-160 \%$. Very high levels are found over India, the Middle East, Southeast Asia, U.S., central Mediterranean and northern China/Japan, e.g. AOT40 values in the U.S. and the central Mediterranean exceed $40 \times 10^{3} \mathrm{nmol} / \mathrm{mol} \mathrm{h}$, SUM06 and W126 reach $95 \times 10^{3} \mathrm{nmol} / \mathrm{mol} \mathrm{h}$. With the exception of Australia, ozone in all regions is now well above the threshold for damaging sensitive vegetation.

\subsection{Climate-air quality interactions}

A preliminary analysis of climate-air quality interactions was made based on three chemistry-climate models (MOZECH, MOZART4 and CHASER_GCM) that provided

25 hourly surface ozone concentrations for the calculation of ozone indices. Figure 10 shows changes in exceedances of EU60, USEPA80, and SOMO35 from scenario S2 to S5, i.e. isolating the climate change effect. The MOZECH model yields much higher exceedances for the U.S. and Europe, while over India it is much lower in the S5 sce-

\section{Multi-model assessment of ozone pollution indices}

K. Ellingsen et al.

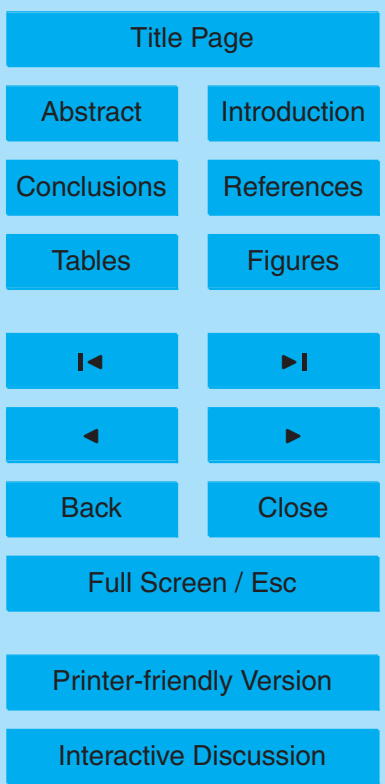


nario. Large effects are also modeled by the MOZART4 model, with large reductions of exceedances over India and China/Japan, especially for the SOMO35 and EU60 indices, indicating a change of background ozone. By and large, the CHASER model calculates smaller effects than the other two models. However, as is obvious from

5 Fig. 10 it must be stressed that the spread between the models is large and there is disagreement even on sign, so that the results must be considered as inconclusive. Future work on the interaction of climate change and ozone should focus on separating out the effects leading to the ozone changes, such as changes in humidity, stratosphere-troposphere exchange, and deposition.

\section{Summary and conclusions}

This study represents, to our knowledge, the most extensive evaluation of surface ozone calculated by using an 18-member ensemble of global chemistry transport models. Our analysis focused on a set of 14 world regions, 13 with a high population density and expected high surface ozone, and one background region. Comparison of 15 modeled ozone with measurements from North America, Europe, and a limited number of measurements from northern China shows relatively good agreement, mostly within $10 \mathrm{nmol} / \mathrm{mol}$. However, large overestimates of ozone, up to $30 \mathrm{nmol} / \mathrm{mol}$ in some seasons, are found for almost all models in Africa, the Middle East and India. Problems with emissions, chemical and meteorological descriptions of the coarse resolution global models may contribute to the discrepancy, but we cannot exclude the possibility that the few measurements available in these regions were not representative. Until more measurements become available model improvement and testing of reasons for discrepancies is precluded. Hourly surface ozone fields from the models were used to estimate health-related air quality indices, since these indices are typically derived 25 from the correlation of results of epidemiological studies with measured hourly surface ozone concentrations (WHO, 2003). We have considered three health related air quality indices: the recently recommended SOMO35, evaluating ozone concen-

\section{Multi-model assessment of ozone pollution indices \\ K. Ellingsen et al.}

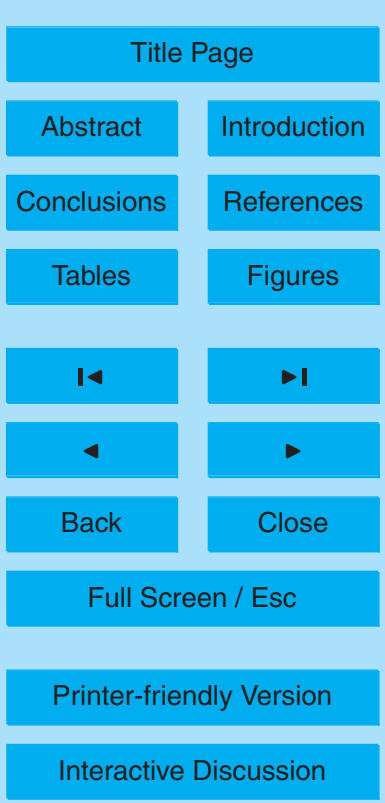

EGU 
trations above a threshold of $35 \mathrm{nmol} / \mathrm{mol}$; EU60, using a threshold of $60 \mathrm{nmol} / \mathrm{mol}$; and USEPA80, evaluating the exceedance of $80 \mathrm{nmol} / \mathrm{mol}$. The large scale correlation of EU60 and USEPA80 with SOMO35 shows that a SOMO35 threshold of ca. 2$2.5 \times 10^{3} \mathrm{nmol} / \mathrm{mol}$ days is broadly consistent with 25 days of exceedance of EU60 and 53 days of exceedance of USEPA80. Since the variation of SOMO35 calculated by the individual model ensemble members is substantially less than for EU60 and USEPA80, it is probably the most robust air quality index when evaluating results from individual models. Air quality standards in the European Union and in the United States state that the EU60 and USEPA80 should not be exceeded on more than 25 and 3 days, 10 respectively. According to our calculations in 10 to 12 out of 14 selected regions the standards are presently exceeded for SOMO35, EU60 and USEPA80. Even if we choose less stringent criteria of $4.8 \times 10^{3} \mathrm{nmol} / \mathrm{mol}$.days, 50 and 6 days for SOMO35, EU60 and USEPA80, respectively, 8 out of 12 world regions are above the limits. We also show that the results are very sensitive to the model accuracy: for instance almost all models would indicate that ozone air quality in the Mediterranean would comply with regulations after correction for a potential bias of annual average ozone by $10 \mathrm{nmol} / \mathrm{mol}$.

We evaluated the impact of three different emission scenarios for the year 2030 . The first (CLE) is based on the socio-economic SRES B2 scenario, but additionally reflects worldwide currently agreed air quality legislation, whilst the second (MFR) also follows SRES B2 but represents an optimistic case assuming that that all technology currently available would be used to achieve emissions reductions. It however does not consider progressive energy use scenarios, or for instance a substantial fuel shift towards hydrogen. We contrast these scenarios with the pessimistic IPCC SRES A2 scenario. The three scenarios reflect current insight regarding the possible range of 25 future air pollution and emission developments.

Compared to the present situation, under CLE only in Europe the ozone air quality somewhat improves, but regional emission reductions measures are counteracted by an increase in global background ozone. Large increases of ozone in exceedance of air quality standards are predicted for India and to a lesser extent for all other world

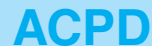

$8,2163-2223,2008$

\section{Multi-model assessment of ozone pollution indices}

K. Ellingsen et al.

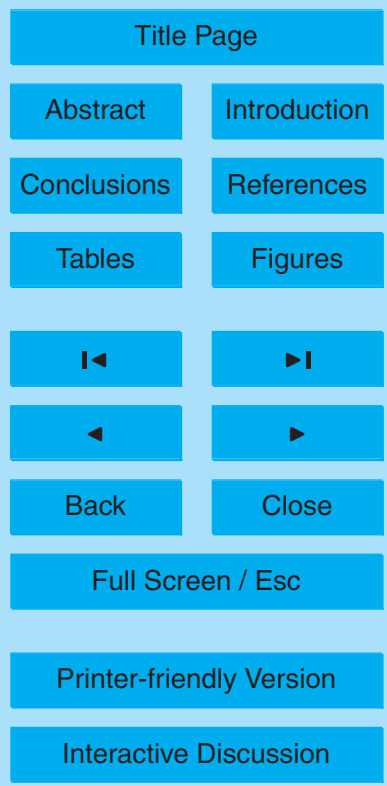


regions.

In contrast, we show that implementation of all currently possible technical measures can strongly improve ozone air quality; using the MFR scenario almost all regions comply with current regulations on air quality. By contrast, the pessimistic SRES A2

5 scenario leads to a dramatic deterioration of global air quality in almost all polluted regions of the world.

\section{Outlook}

Global models continue to improve their resolutions and descriptions of atmospheric chemistry and transport, and they will be increasingly used for regional air quality stud10 ies. This study showed that there are still large limitations and uncertainties related to the use of these models. The present quality of the models to calculate ozone in polluted regions of the world is not high enough for legislative purposes, although e.g. SOMO35 is a robust indicator for changes in future air quality. A further imminent problem is that there are hardly any coordinated networks monitoring ozone outside of

15 Europe and North America, which is a situation that should be addressed as a matter of urgency, given the indications that future high ozone episodes may occur over large parts of Asia and Africa. Concerning the impact of climate change in 2030, our results were inconclusive. More research is needed to detect the small signal of climate change on a near-future time horizon from inter-annual variability and model uncertain20 ties.

Within the framework of the Convention on Long-Range Transboundary Air Pollution, presently covering the UNECE region, the Task Force on Hemispheric Transport on Air Pollution (TF HTAP) has been set up to develop a better understanding of the intercontinental transport of air pollutants in the Northern Hemisphere and to produce estimates of the intercontinental flows of air pollutants for consideration in the review of protocols under the Convention. In the framework of this Task Force more than 20 models participate in assessing contributions of long-range transport to current surface

\section{Multi-model assessment of ozone pollution indices}

K. Ellingsen et al.

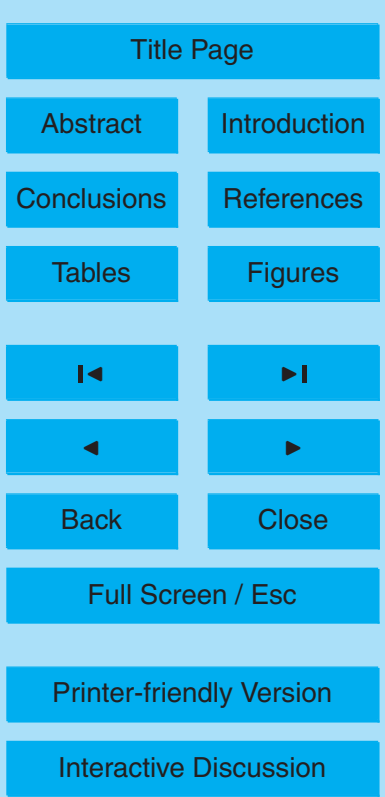

EGU 
ozone values (Fiore et al., $2008^{1}$ ). The study is well underway and builds on the experience from the present ACCENT study. Further systematic analysis of uncertainties in the model descriptions of transport and chemistry will hopefully lead to a further improvement of the models participating in this study.

5 Acknowledgements. This study has been coordinated through the ACCENT network of excellence, funded by the European Commission within Framework Programme 6.

We thank K. Pienaar, O. Pretorius (Sasol), and S. Lal for kindly providing their data, and fruitful discussions. Unpublished data were kindly provided by $\mathrm{H}$. Akimoto and P. Pochanart. We thank G. Carmichael and the Japan Meteorological Agency (JMA) for providing measurement data.

10 We thank IIASA (J. Cofala, Z. Klimont, M. Amann) for providing the emission scenarios used in this work.

\section{References}

Akimoto, H. and Pochanart, P.: Unpublished data obtained in the MEXT project, Research Revolution 2002, 2005.

15 Akimoto, H.: Global air quality and pollution, Science, 302, 1716-1719, 2003.

Andreae, M. O. and Merlet, P.: Emission of trace gases and aerosols from biomass burning, Global Biogeochem. Cy., 15, 955-966, 2001.

Ashmore, M., Emberson, L., Karlsson, P. E., and Pleijel, H.: New Directions: Discussion of A new generation of ozone critical levels for the protection of vegetation in Europe, Atmos.

20 Environ., 39(28), 5214-5215, 2005.

Aunan, K., Berntsen, T. K., and Seip, H. M.: Surface Ozone in China and its possible impact on Agricultural Crop yields, Ambio, 29(6), 294-301, 2000.

Auvray, M. and Bey, I.: Long-range transport to Europe: Seasonal variations and implications for the European ozone budget, J. Geophys. Res., 110, D11303, doi:10.1029/2004JD005503, 2005.

${ }^{1}$ Fiore, A. M., Dentener, F., Wild, O., Cuvelier, C., et al.: Multi-model Estimates of Intercontinental Source-Receptor Relationships for Ozone Pollution, in preperation, 2008.

\section{Multi-model assessment of ozone pollution indices}

K. Ellingsen et al.

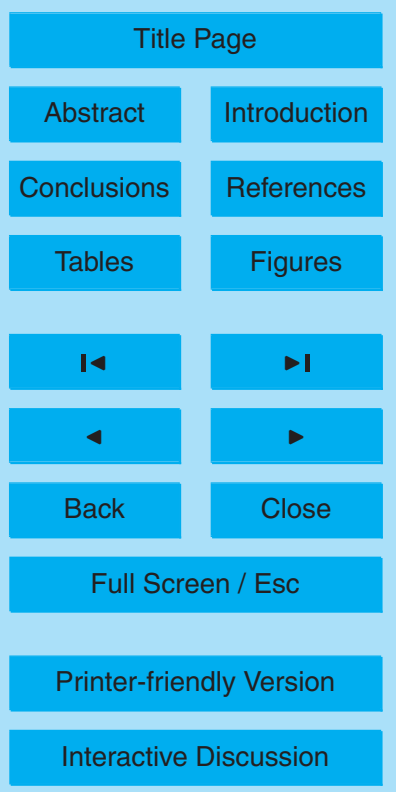


Berntsen, T. K., Karlsdóttir, S., and Jaffe, D. A.: Influence of Asian emissions on the composition of air reaching the North Western United States, Geophys. Res. Lett., 26(14), 2171-2174, 1999.

Bey, I., Jacob, D. J., Logan, J. A., and Yantosca, R. M.: Asian chemical outflow to the Pacific in spring: Origins, pathways, and budgets, J. Geophys. Res., 106 (D19), 23 097-23113, 2001.

Brasseur, G. P., Hauglustaine, D. A., Walters, S., Rasch, P. J. Müller, J.-F., Granier, C., and Tie, X. X.: MOZART, a global chemical transport model for ozone and related chemical tracers: 1. Model description, J. Geophys. Res., 103, 28265-28289, 1998.

Carmichael, G. R., Ferm, M., Thongboonchoo, N., Woo, J.-H., Chan, L. Y., Murano, K., Viet, P. H., Mossberg, C., Bala, R., Boonjawat, J., Upatum, P., Mohan, M., Adhikary, S. P., Shrestha, A. B., Pienaar, J. J., Brunke, E. B., Chen, T., Jie, T., Guoan, D., Peng, L. C., Dhiharto, S., Harjanto, H., Jose, A. M., Kimani, W., Kirouane, A., Lacaux, J., Richard, S., Barturen, O., Cerda, J. C., Athayde, A., Tavares, T., Cotrina, J. S., and Bilici, E.: Measurements of sulfur dioxide, ozone and ammonia concentrations in Asia, Africa, and South America using passive samplers, Atmos. Environ., 37, 1293-1308, 2003.

Cofala, J., Amann, M., Klimont,Z., and Schöpp, W.:Scenarios of World Anthropogenic Emissions of $\mathrm{SO}_{2}, \mathrm{NO}_{x}$, and $\mathrm{CO}$ up to 2030, in Internal report of the Transboundary Air Pollution Programme, pp. 17, available at: http://www.iiasa.ac.at/rains/global_emiss/global_emiss. html, International Institute for Applied Systems Analysis, Laxenburg, Austria, 2005.

Cubasch, U., Meehl, G. A., Boer, G. J., Stouffer, R. J., Dix, M., Noda, A. Senior, C. A., Raper, S., and Yap, K. S.: Projections of future climate change, In: Climate Change 2001: The Scientific Basis, Contribution of WG1 to the Third Assessment report of the IPCC, Eds. Houghton, J.T., et al., Cambridge University Press, England, 2001.

Debaje, S. B., Jeyakumar, S. J., Ganesan, K., Jadhav, D. B., and Seetaramayya, P.: Surface ozone measurements at tropical rural coastal station Tranquebar, India, Atmos. Environ., 37, 4911-4916, 2003.

Dentener, F. J., Carmichael, G. R., Zhang, Y., Lelieveld, J., and Crutzen, P. J.: Role of mineral aerosol as a reactive surface in the global troposphere, J. Geophys. Res., 101, 22869$22889,1996$.

30 Dentener, F., Feichter, J., and Jeuken, A.: Simulation of the transport of $\mathrm{Rn}^{222}$ using on-line and off-line global models at different horizontal resolutions: a detailed comparison with measurements, Tellus, 51B, 573-602, 1999.

Dentener, F., Peters, W., Krol, M., van Weele, M., Bergamaschi, P., and Lelieveld, J.: Interan- 
nual variability and trend of $\mathrm{CH} 4$ lifetime as a measure for $\mathrm{OH}$ changes in the 1979-1993 time period, J. Geophys. Res., 108(D15), 4442, doi:10.1029/2002JD002916, 2003.

Dentener, F., Stevenson, D., Cofala, J., Mechler, R., Amann, M., Bergamaschi, P., Raes, F., and Derwent, R.: The impact of air pollutant and methane emission controls on tropospheric 5 ozone and radiative forcing: CTM calculations for the period 1990-2030, Atmos. Chem. Phys., 5, 1731-1755, SREF-ID:1680-7324/ap/2005-5-1731, 2005.

Dentener, F., Stevenson, D., Ellingsen, K., van Noije, T., Schultz, M., Amann, M., Atherton, C., Bell, N., Bergmann,D., Bey, I., Bouwman, L., Butler, T. Cofala, J., Collins, W., Doherty, R., Drevet, J., Eickhout, B., Fiore, A., Gauss, M., Hauglustaine, D., Horowitz, L., Isaksen, I., Josse, B., Krol, M., Lamarque, J. F., Lawrence, M., Montanaro, V., Müller, J. F., Peuch, V. H., Pitari, G., Pyle, J., Rast, S., Rodriguez, J., Sanderson, M., Savage, N., Shindell, D., Strahan, S., Szopa, S., Sudo, K., Van Dingenen, R., Wild, O., and Zeng, G.: Global Atmospheric Environment for the next generation, Environ. Sci. Technol., 40, 3586-3594, 2006a.

Dentener, F., Drevet, J., Lamarque, J. F., Bey, I., Eickhout, B., Fiore, A. M., Hauglustaine, D., 15 Horowitz, L. W., Krol, M., Kulshrestha, U. C., Lawrence, M., Galy-Lacaux, C., Rast, S. , Shindell, D., Stevenson, D., van Noije, T., Atherton, C., Bell, N., Bergman, D., Butler, T., Cofala, J., Collins,B., Doherty, R., Ellingsen, K., Galloway, J., Gauss, M., Montanaro, V., Müller, J. F., Pitari, G., Rodriguez, J., Sanderson, M., Solmon, F., Strahan, S., Schultz, M., Sudo, K., Szopa, S., and Wild, O.: Nitrogen and sulfur deposition on regional and global scales: a multi-model evaluation; Global Biogeochem. Cy., 20, GB4003, doi:10.1029/2005GB002672, 2006b.

Dentener, F., Kinne, S., Bond, T., Boucher, O., Cofala, J., Generoso, S., Ginoux, P., Gong, S., Hoelzemann, J. J., Ito, A., Marelli, L., Penner, J., Putaud, J.-P., Textor, C., Schulz, M., van der Werf, G. R., and Wilson, J.: Emissions of primary aerosol and precursor gases in the years 2000 and 1750 prescribed data-sets for AeroCom, Atmos. Chem. Phys., 6, 43214344, 2006c.

Derwent, R. G., Stevenson, D. S., Collins, W. J., and Johnson, C. E.: Intercontinental transport and the origins of the ozone observed at surface sites in Europe, Atmos. Environ., 38, 18911901, 2004.

30 Doherty, R. M., Stevenson, D. S., Collins, W. J., and Sanderson, M. G.: Influence of convective transport on tropospheric ozone and its precursors in a chemistry-climate model, Atmos. Chem. Phys., 5, 3205-3218, 2005,

http://www.atmos-chem-phys.net/5/3205/2005/.

\section{Multi-model \\ assessment of ozone pollution indices}

K. Ellingsen et al.

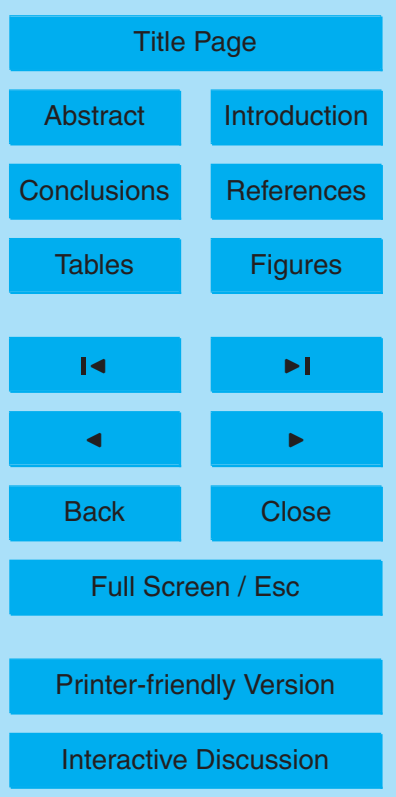


Emberson, L. D., Simpson, D., Tuovinen, J.-P., Ashmore, M. R., and Cambridge, H. M.: Modelling and Mapping ozone deposition in Europe, Water, Air and Soil Pollution, 130, 577-582, 2001.

Emberson, L. D., Ashmore, M., and Murray, F.: Air pollution impacts on crops and forests: A global assessment, Air Pollut. Rev., 4, pp.372, Imperial College Press, London, UK, 2003.

EMEP, Transboundary Acidification, Eutrophication and Ground Level Ozone in Europe in 2003, EMEP Report 1/2005 (http://www.emep.int/publ/common_publications.html\#2005), Oslo, 2005a.

EMEP, The development of European surface ozone. Implications for a revised abatement policy, A contribution from the EU research project NEPAP, edited by: Sverre Solberg and Anne Lindskog, EMEP/CCC-Report 1/2005, 2005b.

Esler, J. G.: An integrated approach to mixing sensitivities in tropospheric chemistry: A basis for the parameterization of subgrid-scale emissions for chemistry transport models, J. Geophys. Res., 108(D20), 4632, doi:10.1029/2003JD003627, 2003.

Fiore, A. M., Jacob, D. J., Field, B. D., Streets, D. G., Fernandes, S. D., and Jang, C.: Linking ozone pollution and climate change: The case for controlling methane, Geophys. Res. Lett., 29(19), 1919, doi:10.1029/2002GL015601, 2002.

Fiore, A., Jacob, D. J., Liu, H., Yantosca, R. M., Fairlie, T. D., Li, Q.: Variability in surface ozone background over the United States: Implications for air quality policy, J. Geophys. Res. 108, 20 4787, doi:10.1029/2003JD003855, 2003.

Fuhrer, J., Skärby, L., Ashmore, M. R.: Critical levels for ozone effects on vegetation in Europe, Environ. Pollut., 97, 91-106, 1997.

Ganzeveld, L. N. and Lelieveld, J.: Dry deposition parameterization in a chemistry general circulation model and its influence on the distribution of reactive trace gases, J. Geophys.

25 Res., 100, 20 999-21 012, 1995.

Grassian, V. H.: Heterogeneous uptake and reaction of nitrogen oxides and volatile organic compounds on the surface of atmospheric particles including oxides, carbonates, soot and mineral dust: implications for the chemical balance of the troposphere, Int. Rev. Phys. Chem., 20(3), 467-548, 2001.

30 Harmens, H., Mills, G., Emberson, L. and Ashmore, M.: Implications of climate change for the stomatal flux of ozone: a case study for winter wheat, Environ. Pollut., doi:10.1016/j.envpol.2006.05.018, 146, 763-770, 2007.

Hauglustaine, D. A., Brasseur, G. P., Walters, S., Rasch, P. J., Müller, J.-F., Emmons, L. K., and

\section{Multi-model \\ assessment of ozone pollution indices}

K. Ellingsen et al.

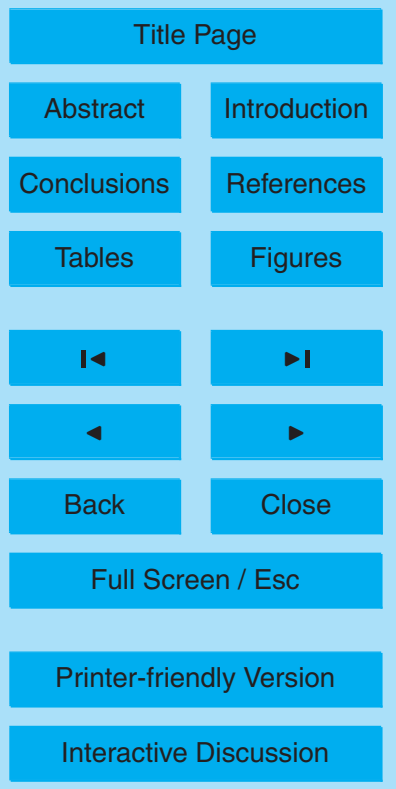


Carroll, M. A.: MOZART: a global chemical transport model for ozone and related chemical tracers: 2. Model results and evaluation, J. Geophys. Res., 103, 28 291-28 335, 1998.

Hauglustaine, D. A., Hourdin, F., Walters, S., Jourdain, L., Filiberti, M.-A., Larmarque, J.-F., and Holland, E. A.: Interactive chemistry in the Laboratoire de Me'te'orologie Dynamique 5 general circulation model: Description and background tropospheric chemistry evaluation, J. Geophys. Res., 109, D04314, doi:10.1029/2003JD003957, 2004.

Hauglustaine, D. A., Lathière, J., Szopa, S., and Folberth, G. A.: Future tropospheric ozone simulated with a climate-chemistry-biosphere model, Geophys. Res. Lett., 32, L24807, doi:10.1029/2005GL024031, 2005.

10 Horowitz, L. W., Walters, S., Mauzerall, D. L., et al.: A global simulation of tropospheric ozone and related tracers: Description and evaluation of MOZART, version 2, J. Geophys. Res., 108(D24), 4784, doi:10.1029/2002JD002853, 2003.

IPCC, 1999: Special Report on Aviation and the Global Atmosphere, Chapter. Eds. Penner, J., Lister, D. H., Griggs, D. J., Dokken, D. J., McFarland, M., Intergovernmental Panel of Climate 15 Change, Cambridge University Press, 121-163, 1999.

IPCC, 2001: Climate Change 2001: The Scientific Basis. Contribution of Working Group I to the Third Assessment Report of the Intergovernmental Panel on Climate Change, Eds. Houghton, J. T., Ding, Y., Griggs, D. J., Noguer, M., van der Linden, P. J., Dai, X., Maskell, K., and Johnson, C. A., Cambridge University Press, Cambridge, United Kingdom and New York, NY, USA, 239-287, 2001.

Isaksen, I. S. A., Zerefos, C. S., Kourtidis, K., Meleti, C., Dalsoren, S. B., Sundet, J. K., Grini, A., Zanis, P., Balis, D.: Tropospheric ozone changes at unpolluted and semipolluted regions induced by stratospheric ozone changes, J. Geophys. Res., 110, doi: 10.1029/2004JD004618, 2005.

Jacob, D. J., Prather, M. J., Rasch, P. J., Shia, R.-L., Balkanski, Y. J., Beagley, S. R., Bergmann, D. J., Blackshear, W. T., Brown, M., Chiba, M., Chipperfield, M. P., de Grandpre, J., Dignon, J. E., Feichter, J., Genthon, C., Grose, W. L., Kasibhatla, P. S., Köhler, I., Kritz, M. A., Law, K., Penner, J. E., Ramonet, M., Reeves, C. E., Rotman, D. A., Stockwell, D. Z., Van Velthoven, P. F. J., Verver, G., Wild, O., Yang, H., and Zimmermann, P.: Evaluation and intercomparison of global atmospheric transport models using 222Rn and other short-lived tracers, J. Geophys. Res., 102(D5), 5953-5970, 1997.

Jacob, D.J.: Heterogeneous chemistry and tropospheric ozone, Atmos. Environ., 34, 21312159, 2000.

\section{Multi-model \\ assessment of ozone pollution indices}

K. Ellingsen et al.

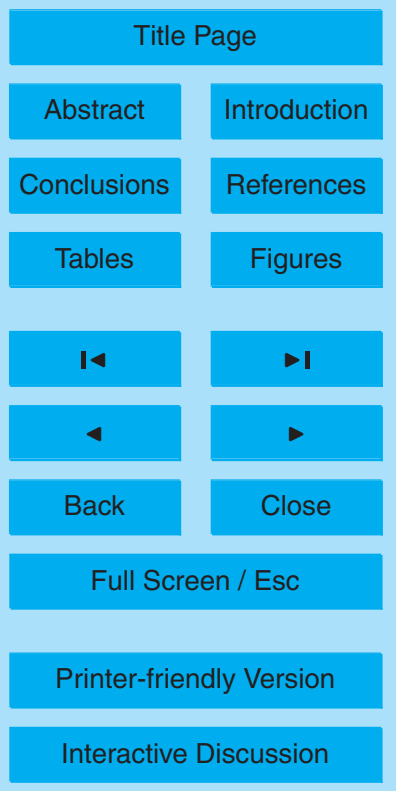


Johns, T. C., Gregory, J. M., Ingram, W. J., Johnson, C. E., Jones, A., Lowe, J. A., Mitchell, J. F. B., Roberts, D. L., Sexton, D. M. H., Stevenson, D. S., Tett, S. F. B., and Woodage, M. J.: Anthropogenic climate change for 1860 to 2100 simulated with the HadCM3 model under updated emissions scenarios, Clim. Dynam., 20, 583-612, doi 10.1007/s00382-002-0296-y, 52003

Jonson, J.E., Simpson, D., Fagerli, H., and Solberg, S.:Can we explain the trends in European ozone levels?, Atmos. Chem. Phys., 6, 51-66, 2006,

http://www.atmos-chem-phys.net/6/51/2006/.

Krol, M., Houweling, S., Bregman, B., van den Broek, M., Segers, A., van Velthoven, P., Peters, W., Dentener, F., and Bergamaschi, B.: The twoway nested global chemistry-transport zoom model TM5: Algorithm and applications, Atmos. Chem. Phys., 5, 417-432, 2005, http://www.atmos-chem-phys.net/5/417/2005/.

Lal, S., Naja, M., and Subbaraya, B. H.: Seasonal variations in surface ozone and its precursors over an urban site in India, Atmos. Environ., 34, 2713-2724, 2000.

15 Lamarque, J.-F., Kiehl, J. T., Hess, P. G., Collins, W. D., Emmons, L. K., Ginoux, P., Luo, C. and Tie, X. X.: Response of a coupled chemistry-climate model to changes in aerosol emissions: Global impact on the hydrological cycle and the tropospheric burdens of $\mathrm{OH}$, ozone and NOx, Geophys. Res. Lett., 32, L16809, doi:10.1029/2005GL023419, 2005.

Law, K. S., Plantevin, P.-H., Shallcross, D. E., Rogers, H. L., Pyle, J. A., Grouhel, C., Thouret, 20 V., and Marenco, A.: Evaluation of modeled $\mathrm{O} 3$ using Measurement of Ozone by Airbus In-Service Aircraft (MOZAIC) data, J. Geophys. Res., 103, 25 721-25 737, 1998.

Law, K. S., Plantevin, P.-H., Thouret, V.,Marenco, A., Asman, W. A. H., Lawrence, M., Crutzen, P. J. , Mu"ller, J.-F., Hauglustaine, D. A. and Kanakidou, M.: Comparison between global chemistry transport model results and Measurement of Ozone by Airbus In-Service Aircraft (MOZAIC) data, J. Geophys. Res., 105, 1503-1525, 2000.

Lawrence, M. G., Crutzen, P. J., Rasch, P. J., Eaton, B. E. and Mahowald, N. M.: A model for studies of tropospheric photochemistry: Description, global distributions, and evaluation, J. Geophys. Res., 104, 26,245-26 277, 1999.

Lawrence, M. G., von Kuhlmann, R., Salzmann, M., and Rasch, P. J.: The balance of ef30 fects of deep convective mixing on tropospheric ozone, Geophys. Res. Lett., 30, 1940, doi:10.1029/2003GL017644, 2003.

Lefohn, A. S., and Runeckles, V. C.: Establishing a standard to protect vegetation - ozone exposure/dose considerations, Atmos. Environ., 21, 561-568, 1987.

\section{Multi-model \\ assessment of ozone pollution indices}

K. Ellingsen et al.

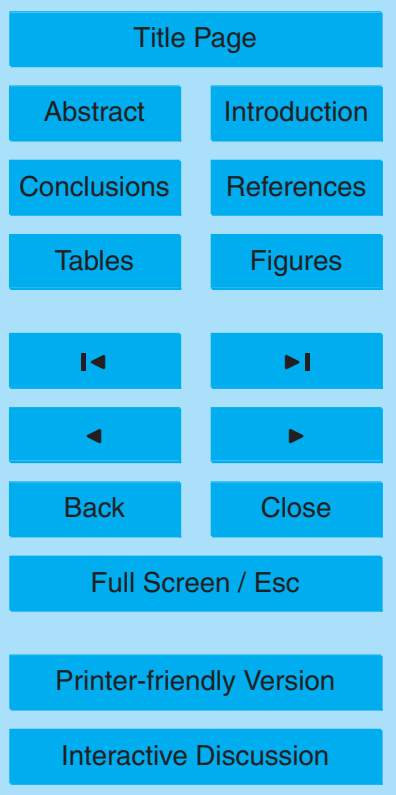


Lefohn, A. S., Laurence, J. A. and Kohut, R. J.: A comparison of indices that describe the relationship between exposure to ozone and reduction in the yield of agricultural crops, Atmos. Environ., 22, 1229-1240, 1988.

Leggett, J., Pepper, W. J., and Swart, R. J.: Emissions scenarios for the IPCC: an update, 5 In: Climate Change 1992, The supplementary report to the IPCC scientific assessment, Cambridge University Press, UK, pp. 200, 1992.

Li, Q., Jacob, D. J., Bey, I., Palmer, P. I., Duncan, B. N., Field, B. D., Martin, R. V., Fiore, A. M., Yantosca,R. M., Parrish, D. D., Simmonds, P. G., and Oltmans, S. J.: Transatlantic transport of pollution and its effects on surface ozone in Europe and North America, J. Geophys. Res., 107(D13), doi:10.1029/2001JD001422, 2002.

Martin, R. V., Jacob, D. J, Yantosca, R., Chin, M. and Ginoux, P.: Global and regional decreases in tropospheric oxidants from photochemical effects of aerosols, J. Geophys. Res., 108(D3), 4097, doi:10.1029/2002JD002622, 2003.

Mauzerall, D. M., and Wang, X.: Protecting agricultural crops from the effects of tropospheric 15 Ozone exposure: Reconciling science and standard setting in the United States, Europe and Asia, Ann. Rev. Energy and the Environment, 26, 237-268, 2001.

Murazaki, K. and Hess, P.: How does climate change contribute to surface ozone change over the United States?, J. Geophys. Res., D05301, doi:10.1029/2005JD005873, 2006.

Nair, P. R., Chand, D., Lal, S., Modh, K. S., Naja, M., Parameswaran, K. Ravindran, S., 20 Venkataramani, S.: Temporal variations in surface ozone at Thumba $\left(8.6^{\circ} \mathrm{N}, 77^{\circ} \mathrm{E}\right)-$ a tropical coastal site in India, Atmos. Environ., 36, 603-610, 2002.

Naja, M. and Lal, S.: Surface ozone and precursor gases at Gadanki (13.5 N, 79.2 E), a tropical rural site in India, J. Geophys. Res., 107, ACH8 1-13, 2002.

Naja, M., Lal, S., Chand, D.: Diurnal and seasonal variabilities in surface ozone at a high 25 altitude site Mt Abu (24.6 $6^{\circ}, 72.7^{\circ} \mathrm{E}, 1680 \mathrm{~m}$ asl) in India, Atmos. Environ., 37, 4205-4215, 2003.

Nakicenovic, N., Alcamo, J., Davis, G., et al., IPCC Special Report on Emissions Scenarios, Cambridge University Press, Cambridge, UK, 570 pp., 2000.

Olivier, J. G. J., and Berdowski, J. J. M.: Global emissions sources and sinks, in The climate system, edited by: Berdowski, J. J. M., Guicherit, R., Heij, B. J., and Balkema, A. A., Publishers/Swets \& Zeitlinger Publishers, Lisse, The Netherlands, 2001.

Park, R. J., Jacob, D. J., Field, B. D., Yantosca, R. M. and Chin, M.: Natural and transboundary pollution influences on sulfate-nitrateammonium aerosols in the United States: Implications

\section{Multi-model \\ assessment of ozone pollution indices}

K. Ellingsen et al.

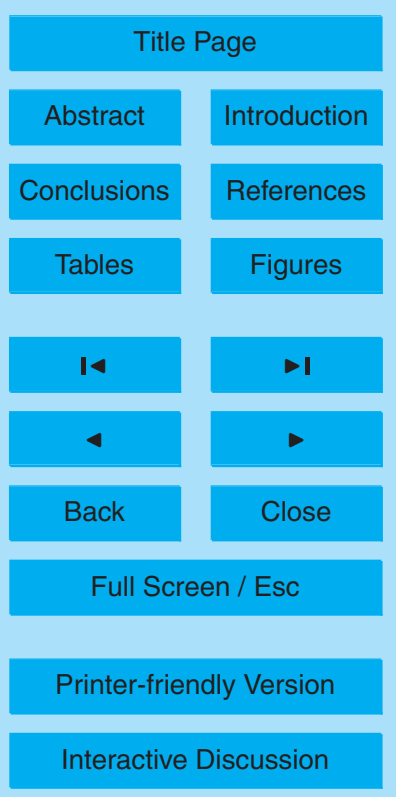

EGU 
for policy, J. Geophys. Res., 109, D15204, doi:10.1029/2003JD004473, 2004.

Prather, M., Ehhalt, D., Dentener, F., et al.., Atmospheric Chemistry and Greenhouse Gases, in: Climate Change 2001: The Scientific Basis, Contribution of WG1 to the Third Assessment report of the IPCC, Eds. Houghton, J.T., et al., Cambridge University Press, England, 2001.

5 Prather, M., Gauss, M., Berntsen, T. K., et al.: Fresh air in the 21st century, Geophys. Res. Lett, 30(2), 72-72-4, 2003.

Rasch, P. J., Mahowald, N. M., and Eaton, B. E.: Representations of transport, convection and the hydrologic cycle in chemical transport models: Implications for the modeling of short lived and soluble species, J. Geophys. Res., 102, 28 127-28 138, 1997.

10 Röckner, E., Bäuml, G., Bonaventura, L., et al.: The atmospheric general circulation model ECHAM 5. Part I: Model description, Rep. 349, Max Planck Inst. for Meteorol., Hamburg, Germany, (available at: http://edoc.mpg.de/get.epl?fid=18449\&did=175329\&ver=0), 2003.

Rotman, D. A., Atherton, C. S., Bergmann, D. J., et al.: IMPACT, the LLNL 3-D global atmospheric chemical transport model for the combined troposphere and stratosphere: Model description and analysis of ozone and other trace gases, J. Geophys. Res., 109, D04303, doi:10.1029/2002JD003155, 2004.

Sadourny, R., and Laval, K.: January and July performance of the LMD general circulation model, in New Perspectives in Climate Modeling, edited by A. Berger and C. Nicolis, 173197, Elsevier, New York, 1984.

Shindell, D. T., Falugvegi, G., Stevenson, D. S., et al.: Multi-model simulations of carbon monoxide: Comparison with observations and projected near future changes., J. Geophys. Res., 111, D19306, doi:10.1029/2006JD007100, 2006.

Simmonds, P. G., Derwent, R. G., Manning, A. J., and Spain, G.: Significant growth in surface ozone at Mace Head, Ireland 1987-2003, Atmos. Environ., 38, 4769-4778, 2004.

Sitch, S., Cox, P. M., Collins, W. J., and Huntingford, C.: Indirect radiative forcing of climate change through ozone effects on the land carbon sink, Nature, 448,doi:10.1038/nature06059, 2007.

Staehelin, J., Thudium, J., Buehler, R., Volz-Thomas, A., and Graber, W.: Trends in surface ozone concentrations at Arosa (Switzerland), Atmos. Environ., 28, 75-87, 1994.

30 Stevenson, D. S., Doherty, R. M. Sanderson, M. G., Johnson, C. E., Collins, W. J., and Derwent, R. G.: Impacts of climate change and variability on tropospheric ozone and its precursors, Faraday Discuss., 130, doi:10.1039/b417412g, 2005.

Stevenson, D. S., Dentener, F. J., Schultz, M. G., et al.: Multi-model ensemble simula-

\section{Multi-model \\ assessment of ozone pollution indices}

K. Ellingsen et al.

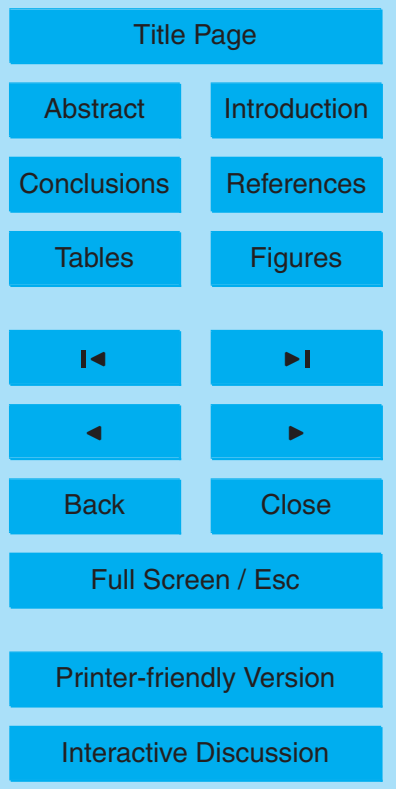


tions of present-day and near-future tropospheric ozone, J. Geophys. Res., 111, D08301, doi:10.1029/2005JD006338, 2006.

Streets, D. G., Bond, T. C., Carmichael, G. R., Fernandes, S. D., Fu, Q., He, D., Klimont, Z., Nelson, S. M., Tsai, N. Y., Wang, M. Q., Woo, J.-H., Yarber, K. F.: An inventory of gaseous and primary aerosol emissions in Asia in the year 2000, J. Geophys. Res., 108(D21), 8809, doi:10.1029/2002JD003093, 2003.

Sudo, K., Takahashi, M., Kurokawa, J., and Akimoto, H.: CHASER: A global chemical model of the troposphere: 1. Model description, J. Geophys. Res., 107(D17), 4339, doi:10.1029/2001JD001113, 2002a.

10 Sudo, K., Takahashi, M., and Akimoto, H.: CHASER: A global chemical model of the troposphere: 2. Model results and evaluation, J. Geophys. Res., 107(D21), 4586, doi:10.1029/2001JD001114, 2002b.

Sudo, K., Takahashi, M., and Akimoto, H.: Future changes in stratosphere-troposphere exchange and their impacts on future tropospheric ozone simulations, Geophys. Res. Lett., 30, 152256 10.1029/2003GL018526, 2003.

Szopa, S., Hauglustaine, D. A., Vautard, R., and Menut, L.: Future global tropospheric ozone changes and impact on European air quality, Geophys. Res. Lett., 33, L14805, doi:10.1029/2006GL025860, 2006.

Szopa, S. and Hauglustaine, D. A.: Relative impacts of worldwide tropospheric ozone changes and regional emission modifications on European surface-ozone levels, C. R. Geoscience, doi:10.1016/j.crte.2007.08.013, in press, 2007.

Tie, X. X., Madronich, S., Walters, S., Edwards, D. P., Ginoux, P., Mahowald, N., Zhang, R., Lou, C., and Brasseur, G.: Assessment of the global impact of aerosols on tropospheric oxidants, J. Geophys. Res., 110, D03204, doi:10.1029/2004JD005359, 2005.

USEPA, Fact Sheet: EPA's revised ozone standard, Washington, DC, available at: http://yosemite.epa.gov/opa/admpress.nsf/72300d00bae91a3185257359003d4805/ 809fdce1144e4b60852564d70041a8a6!OpenDocument, 1997.

USEPA, Ozone and Your Health, EPA-452/F-99-003, available at: www.airnow.gov, 1999.

USEPA, Evaluating ozone control programs in the Eastern United States: Focus on the NOx budget trading program, 2004, EPA454-K-05-001, available at: www.epa.gov/airtrends, Washington, DC, 2005.

van der Werf, G. R., Randerson, T. J., Collatz, J., and Giglio, L.: Carbon emissions from fires in tropical and subtropical ecosystems, Global Change Biol., 9, 547-562, 2003.

\section{Multi-model \\ assessment of ozone pollution indices}

$\mathrm{K}$. Ellingsen et al.

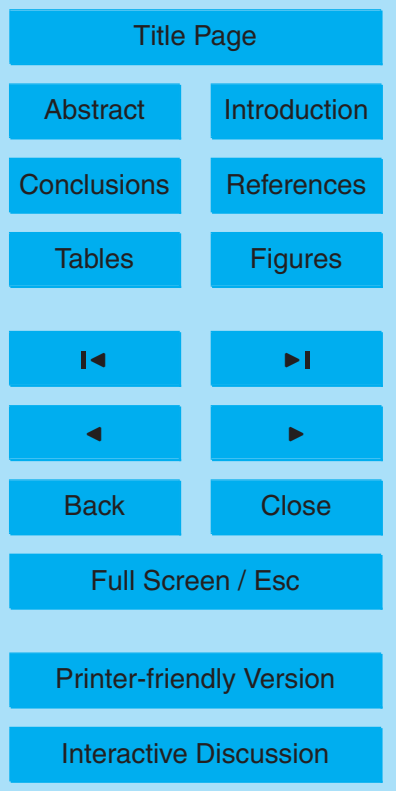


van Loon, M., Vautard, R., Schaap, M., Bergström, R., Bessagnet, B., Brandt, J., Builtjes, P. J. H., Christensen, J. H., Cuvelier, C., Graff, A., Jonson, J. E., Krol, M., Langner, J., Roberts, P., Rouil, L., Stern, R., Tarrasón, L., Thunis, P., Vignati, E., White, L., and Wind, P.: Evaluation of long-term ozone simulations from seven regional air quality models and their ensemble,

$5 \quad$ Atmos. Environ., 41, 2083-2097, 2007.

van Noije, T. P. C., Eskes, H. J., van Weele, M., and van Velthoven, P. F. J.: Implications of the enhanced Brewer-Dobson circulation in European Centre for Medium-Range Weather Forecasts reanalysis ERA-40 for the stratosphere-troposphere exchange of ozone in global chemistry-transport models, J. Geophys. Res., 109, D19308, doi:10.1029/2004JD004586, $10 \quad 2004$

van Noije, T. P. C., Eskes, H. J., Dentener, F. J., Stevenson, D. S., Ellingsen, K., Schultz, M. G., Wild, O., Amann, M., AthertonC. S., Bergmann, D. J., Bey, I., Boersma, K. F., Butler, T., Cofala, J., Drevet, J., Fiore, A. M., Gauss, M., Hauglustaine, D. A., Horowitz, L. W., Isaksen, I. S. A., Krol, M. C., Lamarque, J.-F., Lawrence, M. G., Martin, R. V., Montanaro, V., Müller, J.15 F., Pitari, G., Prather, M. J., Pyle, J. A., Richter, A., Rodriguez, J. M., Savage, N. H., Strahan, S. E., Sudo, K., Szopa, S., and van Roozendael, M.: Multi-model ensemble simulations of tropospheric $\mathrm{NO}_{2}$ compared with GOME retrievals for the year 2000, Atmos. Chem. Phys., 6, 2943-2979, 2006,

http://www.atmos-chem-phys.net/6/2943/2006/. tropospheric ozone and nonmethane hydrocarbons: Model description and ozone results, J. Geophys. Res., 108(D9), 4294, doi:10.1029/2002JD002893, 2003a.

von Kuhlmann, R., Lawrence, M. G., Crutzen, P. J., and Rasch, P. J.: A model for studies of tropospheric ozone and nonmethane hydrocarbons: Model evaluation of ozone-related species, J. Geophys. Res., 108(D23), 4729, doi:10.1029/2002JD003348, 2003b.

Wang, X. and Mauzerall, D.: Characterizing distributions of surface ozone and its impact on grain production in China, Japan and South Korea: 1990 and 2020, Atmos. Environ., 38, 4383-4402, 2004.

Wesely, M. L.: Parameterization of surface resistance to gaseous dry deposition in regionalscale numerical models, Atmos. Environ., 23, 1293-1304, 1989.

West, J. J. and Fiore, A. M.: Management of Tropospheric Ozone by Reducing Methane Emissions, Environ. Sci. Technol., 39, 4685-4691, 2005.

West, J. J., Fiore, A. M., Horowitz, L. W., and Mauzerall, D. L.: Global health benefits of mitigat-

\section{Multi-model \\ assessment of ozone pollution indices}

K. Ellingsen et al.

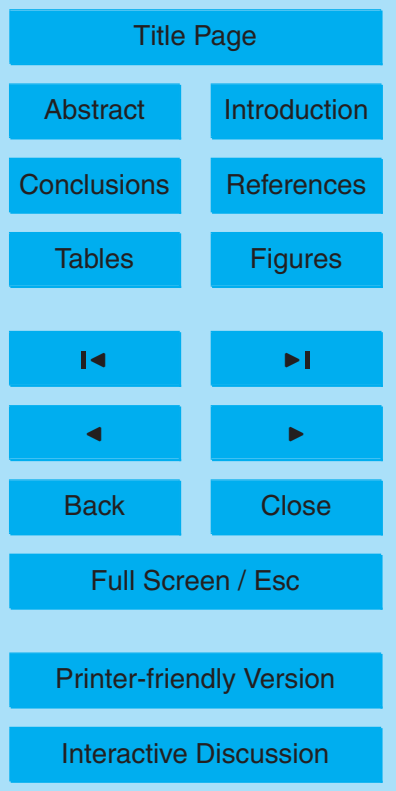


ing ozone pollution with methane emission controls, Proceeding of the National Academy of Sciences of the United States of America, 103(11), 3988-3993, 2006.

West, J. J., Szopa, S., and Hauglustaine, D. A.: Human mortality effects of future concentrations of tropospheric ozone, C. R. Geoscience, 339(11-12), 775-783, doi:10.1016/j.crte.2007.08.005, 2007.

WHO, Air Quality Guidelines for Europe, 2nd Edition, WHO Regional Publications, European Series, 91, Copenhagen, 2000.

WHO, Health Aspects of Air Pollution with Particulate Matter, Ozone and Nitrogen Dioxide, pp. 98, World Health Organisation, Bonn, Germany, 2003.

Wild, O. and Akimoto, H.: Intercontinental transport of ozone and its precursors in a threedimensional global CTM, J. Geophys. Res., 106, 27 729-27 744, 2001.

Wild, O. and Prather, M. J.: Excitation of the primary tropospheric chemical mode in a global 3-D model, J. Geophys. Res., 105, 24 647-24 660, 2000.

Wild, O., Sundet, J.K., Prather, M. J., Isaksen, I. S. A., Akimoto, H., Browell, E. V., and Oltmans, S. J.: CTM ozone simulations for spring 2001 over the western Pacific: Comparisons with TRACE-P Lidar, ozonesondes and TOMS columns, J. Geophys. Res., 108(D21), 8826, doi:10.1029/2002JD003283, 2003.

Wild, O., and Prather, M. J.: Global tropospheric ozone modeling: Quantifying errors due to grid resolution, J. Geophys. Res., 111, D11305, doi:10.1029/2005JD006605, 2006.

Zeng, G. and Pyle, J. A.: Changes in tropospheric ozone between 2000 and 2100 modeled in a chemistry-climate model, Geophys. Res. Lett., 30(7), 1392, doi:10.1029/2002GL016708, 2003.

Zunckel, M., Venjonoka, K., Pienaar, J. J., Brunke, E. G., Pretorius, O., Koosialee, A., Raghunandan, A., and van Tienhoven, A. M.: Surface ozone over Southern Africa: synthesis of Environ., 38, 6139-6147, 2004.

\section{ACPD}

8, 2163-2223, 2008

\section{Multi-model \\ assessment of ozone pollution indices}

K. Ellingsen et al.

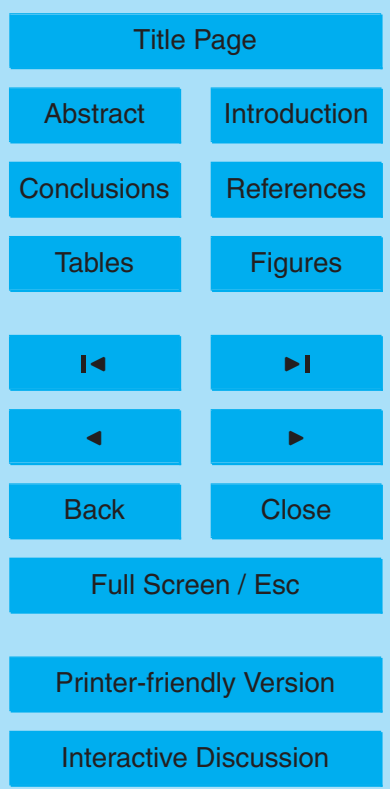


Table 1. Overview of the models that submitted results for this study.

\begin{tabular}{|c|c|c|c|c|c|c|}
\hline Model & Institute & Contact author & $\begin{array}{l}\text { Resolution } \\
\text { (lon/lat/levels) } \\
\text { Top level }\end{array}$ & $\begin{array}{l}\text { Underlying } \\
\text { meteorology }\end{array}$ & Tropospheric chemistry & References \\
\hline $\begin{array}{l}\text { CHASER } \\
\text { CTM }\end{array}$ & FRCGC JAMSTEC & K. Sudo & $\begin{array}{l}2.8^{\circ} / 2.8^{\circ} / \mathrm{L} 32 \\
3 \mathrm{hPa}\end{array}$ & $\begin{array}{l}\text { CTM: } \\
\text { ECMWF }\end{array}$ & $\begin{array}{l}53 \text { species } \\
\text { Interactive } \mathrm{SO}_{4} \text { aerosol }\end{array}$ & $\begin{array}{l}\text { Sudo et al. (2002a, b) } \\
\text { Sudo et al. (2003) }\end{array}$ \\
\hline $\begin{array}{l}\text { CHASER } \\
\text { GCM }\end{array}$ & FRCGC JAMSTEC & K. Sudo & $\begin{array}{l}2.8^{\circ} / 2.8^{\circ} / \mathrm{L} 32 \\
3 \mathrm{hPa}\end{array}$ & $\begin{array}{l}\text { GCM: } \\
\text { CCSR/NIES }\end{array}$ & $\begin{array}{l}53 \text { species } \\
\text { Interactive } \mathrm{SO}_{4} \text { aerosol }\end{array}$ & $\begin{array}{l}\text { Sudo et al. (2002a, b) } \\
\text { Sudo et al. (2003) }\end{array}$ \\
\hline $\begin{array}{l}\text { FRSGC } \\
\text { UCl }\end{array}$ & $\begin{array}{l}\text { FRCGC } \\
\text { JAMSTEC }\end{array}$ & O. Wild & $\begin{array}{l}2.8^{\circ} / 2.8^{\circ} / \mathrm{L} 37 \\
10 \mathrm{hPa}\end{array}$ & $\begin{array}{l}\text { CTM: } \\
\text { ECMWF-IFS pieced- } \\
\text { forecast data for } 2000\end{array}$ & $\begin{array}{l}35 \text { species } \\
\text { (27 transported), } \\
\text { using ASAD } \\
\text { (Carver et al., 1997) }\end{array}$ & $\begin{array}{l}\text { Wild and Prather (2000) } \\
\text { Wild et al. (2003) }\end{array}$ \\
\hline $\begin{array}{l}\text { GEOS- } \\
\text { CHEM }\end{array}$ & LMCA-EPFL & $\begin{array}{l}\text { I. Bey } \\
\text { J. Drevet }\end{array}$ & $\begin{array}{l}5^{\circ} / 4^{\circ} / \mathrm{L} 30 \\
0.01 \mathrm{hPa}\end{array}$ & $\begin{array}{l}\text { CTM: } \\
\text { GEOS winds } \\
\text { NASA GMAO }\end{array}$ & $\begin{array}{l}31 \text { tracers }\left(24 \text { for } \mathrm{O}_{x}, 7 \text { for }\right. \\
\mathrm{SO}_{\mathrm{x}}-\mathrm{NH}_{\mathrm{x}}-\mathrm{NO}_{\mathrm{y}} \text { aerosols, } \\
\text { interactive). }\end{array}$ & $\begin{array}{l}\text { Bey et al. (2001) } \\
\text { Martin et al. (2003) } \\
\text { Park et al. (2004) }\end{array}$ \\
\hline $\begin{array}{l}\text { GMI } \\
\text { CCM3 }\end{array}$ & $\begin{array}{l}\text { NASA Global } \\
\text { Modeling Initiative }\end{array}$ & $\begin{array}{l}\text { J. M. Rodriguez } \\
\text { S. Strahan }\end{array}$ & $\begin{array}{l}5^{\circ} / 4^{\circ} / \mathrm{L} 52 \\
0.006 \mathrm{hPa}\end{array}$ & $\begin{array}{l}\text { GCM: } \\
\text { NCAR } \\
\text { MACCM3 }\end{array}$ & $\begin{array}{l}85 \text { species } \\
\text { Off-line } \mathrm{SO}_{\mathrm{x}} \text { aerosol }\end{array}$ & $\begin{array}{l}\text { Bey et al. (2001) } \\
\text { Martin et al. (2003) } \\
\text { Park et al. (2004) }\end{array}$ \\
\hline $\begin{array}{l}\text { GMI } \\
\text { DAO }\end{array}$ & $\begin{array}{l}\text { NASA Global } \\
\text { Modeling Initiative }\end{array}$ & $\begin{array}{l}\text { J. M. Rodriguez } \\
\text { S. Strahan }\end{array}$ & $\begin{array}{l}5^{\circ} / 4^{\circ} / \mathrm{L} 46 \\
0.048 \mathrm{hPa}\end{array}$ & $\begin{array}{l}\text { CTM: } \\
\text { GEOS-2-DAS } \\
\text { Assimilated fields for } \\
\text { March 1997-Feb } 1998 .\end{array}$ & $\begin{array}{l}85 \text { species } \\
\text { Off-line } \mathrm{SO}_{\mathrm{x}} \text { aerosol }\end{array}$ & $\begin{array}{l}\text { Bey et al. (2001) } \\
\text { Martin et al. (2003) } \\
\text { Park et al. (2004) }\end{array}$ \\
\hline $\begin{array}{l}\text { GMI } \\
\text { GISS }\end{array}$ & $\begin{array}{l}\text { NASA Global } \\
\text { Modeling Initiative }\end{array}$ & $\begin{array}{l}\text { J. M. Rodriguez } \\
\text { S. Strahan }\end{array}$ & $\begin{array}{l}5^{\circ} / 5^{\circ} / \mathrm{L} 23 \\
0.017 \mathrm{hPa}\end{array}$ & $\begin{array}{l}\text { GCM: } \\
\text { GISS-2, }\end{array}$ & $\begin{array}{l}85 \text { species } \\
\text { Off-line } \mathrm{SO}_{\mathrm{x}} \text { aerosol }\end{array}$ & $\begin{array}{l}\text { Bey et al. (2001) } \\
\text { Martin et al. (2003) } \\
\text { Park et al. (2004) }\end{array}$ \\
\hline $\begin{array}{l}\text { LLNL- } \\
\text { IMPACT }\end{array}$ & $\begin{array}{l}\text { Lawrence Livermore } \\
\text { National Laboratory }\end{array}$ & $\begin{array}{l}\text { C. S. Atherton } \\
\text { D. J. Bergmann }\end{array}$ & $\begin{array}{l}5^{\circ} / 5^{\circ} / \mathrm{L} 26 \\
2 \mathrm{hPa}\end{array}$ & $\begin{array}{l}\text { GCM: } \\
\text { CAM3 }\end{array}$ & $\begin{array}{l}100 \text { species } \\
\text { Including } \mathrm{Cl}_{\mathrm{x}}, \mathrm{Br}_{\mathrm{y}}\end{array}$ & Rotman et al. (2004) \\
\hline $\begin{array}{l}\text { LMDz } \\
\text { INCA } \\
\text { CTM }\end{array}$ & LSCE & $\begin{array}{l}\text { D. Hauglustaine } \\
\text { S. Szopa }\end{array}$ & $\begin{array}{l}3.75^{\circ} / 2.5^{\circ} / \mathrm{L} 19 \\
3 \mathrm{hPa}\end{array}$ & $\begin{array}{l}\text { CTM: } \\
\text { nudged to ECMWF } \\
\text { ERA15 ERA40-OD }\end{array}$ & 85 species & $\begin{array}{l}\text { Sadourney and Laval (1984) } \\
\text { Hauglustaine et al. (2004) }\end{array}$ \\
\hline $\begin{array}{l}\text { MATCH- } \\
\text { MPIC } \\
\text { ECMWF }\end{array}$ & $\begin{array}{l}\text { Max Planck Institute } \\
\text { for Chemistry NCAR }\end{array}$ & $\begin{array}{l}\text { T. Butler } \\
\text { M. Lawrence }\end{array}$ & $\begin{array}{l}5.6^{\circ} / 5.6^{\circ} / \mathrm{L} 28 \\
2 \mathrm{hPa}\end{array}$ & $\begin{array}{l}\text { CTM: } \\
\text { ECMWF reanalysis }\end{array}$ & 60 species & $\begin{array}{l}\text { von Kuhlmann et al. } \\
(2003 a, b) \\
\text { Lawrence et al. (1999) } \\
\text { Rasch et al. (1997) }\end{array}$ \\
\hline
\end{tabular}

ACPD

8, 2163-2223, 2008

\section{Multi-model assessment of ozone pollution indices}

$\mathrm{K}$. Ellingsen et al.

Title Page

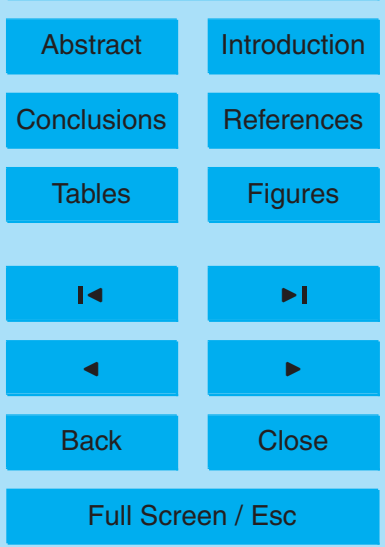

Printer-friendly Version

Interactive Discussion 


\section{ACPD}

8, 2163-2223, 2008

Table 1. Continued.

\begin{tabular}{|c|c|c|c|c|c|c|}
\hline $\begin{array}{l}\text { MATCH } \\
\text { MPIC } \\
\text { NCEP }\end{array}$ & $\begin{array}{l}\text { Max Planck Institute } \\
\text { for Chemistry NCAR }\end{array}$ & $\begin{array}{l}\text { T. Butler } \\
\text { M. Lawrence }\end{array}$ & $\begin{array}{l}5.6^{\circ} / 5.6^{\circ} / \mathrm{L} 28 \\
2 \mathrm{hPa}\end{array}$ & $\begin{array}{l}\text { CTM: } \\
\text { NCEP/NCAR } \\
\text { reanalysis }\end{array}$ & 60 species & $\begin{array}{l}\text { von Kuhlmann et al. } \\
\text { (2003a, b) } \\
\text { Lawrence et al. (1999) } \\
\text { Rasch et al. (1997) }\end{array}$ \\
\hline $\begin{array}{l}\text { MOZ2 } \\
\text { GFDL }\end{array}$ & GFDL & $\begin{array}{l}\text { A. Fiore } \\
\text { L. Horowitz }\end{array}$ & $\begin{array}{l}1.9^{\circ} / 1.9^{\circ} / \mathrm{L} 28 \\
0.7 \mathrm{hPa}\end{array}$ & $\begin{array}{l}\text { CTM: } \\
\text { NCEP } \\
\text { reanalysis }\end{array}$ & $\begin{array}{l}74 \text { species } \\
\text { Interactive } \mathrm{SO}_{\mathrm{x}} \\
\mathrm{BC} \text { aerosols }\end{array}$ & $\begin{array}{l}\text { Brasseur et al. (1998) } \\
\text { Hauglustaine et al. (1998) } \\
\text { Horowitz et al. (2003) }\end{array}$ \\
\hline MOZART4 & NCAR & J.-F. Lamarque & $\begin{array}{l}2.8^{\circ} / 2.8^{\circ} / \mathrm{L} 26 \\
4 \mathrm{hPa}\end{array}$ & $\begin{array}{l}\text { GCM: } \\
\text { CCSM3 }\end{array}$ & $\begin{array}{l}96 \text { species } \\
\text { Aerosols } \mathrm{SO}_{\mathrm{x}}, \mathrm{NH}_{3}, \quad \mathrm{NO}_{3} \text {, } \\
\text { BC/OC, seasalt, } \mathrm{SOA} \text {. }\end{array}$ & $\begin{array}{l}\text { Horowitz et al. (2003) } \\
\text { Tie et al. (2005) } \\
\text { Lamarque et al. (2005) }\end{array}$ \\
\hline MOZECH & MPI Meteorology & $\begin{array}{l}\text { M. G. Schultz } \\
\text { S. Rast }\end{array}$ & $\begin{array}{l}2.8 / 2.8 / \mathrm{L} 31 \\
10 \mathrm{hPa}\end{array}$ & $\begin{array}{l}\text { GCM: } \\
\text { ECHAM5 }\end{array}$ & $\begin{array}{l}63 \text { species } \\
\mathrm{SO}_{4} \text { climatology }\end{array}$ & $\begin{array}{l}\text { ECHAM5 described in } \\
\text { Roeckner et al. (2003) } \\
\text { MOZART-2 described in } \\
\text { Horowitz et al. (2003) }\end{array}$ \\
\hline p-TOMCAT & $\begin{array}{l}\text { University } \\
\text { of Cambridge UK }\end{array}$ & N. Savage & $\begin{array}{l}2.8^{\circ} / 2.8^{\circ} / \mathrm{L} 31 \\
10 \mathrm{hPa}\end{array}$ & $\begin{array}{l}\text { ECMWF } \\
\text { Operational analysis } \\
\text { data }\end{array}$ & 37 species incl. NMHCs. & Law et al. $(1998,2000)$ \\
\hline TM4 & KNMI & T. v. Noije & $\begin{array}{l}3^{\circ} / 2^{\circ} / \mathrm{L} 25 \\
0.48 \mathrm{hPa}\end{array}$ & $\begin{array}{l}\text { CTM: } \\
\text { ECMWF 3-6-h opera- } \\
\text { tional forecasts (2000) }\end{array}$ & $\begin{array}{l}37 \text { species } \\
(22 \text { transported) } \\
\mathrm{SO}_{\mathrm{x}}-\mathrm{NOy}^{-\mathrm{NH}_{\mathrm{x}}} \text { aerosols }\end{array}$ & $\begin{array}{l}\text { Dentener et al. (2003) } \\
\text { van Noije et al. (2004) }\end{array}$ \\
\hline TM5 & JRC & $\begin{array}{l}\text { F. Dentener } \\
\text { M. Krol }\end{array}$ & $\begin{array}{l}6^{\circ} / 4^{\circ} / \mathrm{L} 25 \\
0.48 \mathrm{hPa} \\
{\left[1^{\circ} / 1^{\circ} \text { Europe, }\right.} \\
\mathrm{N} . \quad \text { America, } \\
\text { and Asia] }\end{array}$ & $\begin{array}{l}\text { CTM: } \\
\text { ECMWF 3-6-h opera- } \\
\text { tional forecasts (2000) }\end{array}$ & $\begin{array}{l}37 \text { species } \\
(22 \text { transported }) \\
\mathrm{SO}_{x}-\mathrm{NOy}-\mathrm{NH}_{\mathrm{x}} \text { aerosols, in- } \\
\text { teractive }\end{array}$ & $\begin{array}{l}\text { Dentener et al. (2003) } \\
\text { Krol et al. (2005) }\end{array}$ \\
\hline $\begin{array}{l}\text { UIO } \\
\text { CTM2 }\end{array}$ & University of Oslo & $\begin{array}{l}\text { K. Ellingsen } \\
\text { M. Gauss }\end{array}$ & $\begin{array}{l}2.8^{\circ} / 2.8^{\circ} / \mathrm{L} 40 \\
10 \mathrm{hPa}\end{array}$ & $\begin{array}{l}\text { CTM: } \\
\text { ECMWF-IFS } \\
\text { forecast data }\end{array}$ & 58 species & Isaksen et al. (2005) \\
\hline
\end{tabular}

\section{Multi-model assessment of ozone pollution indices}

K. Ellingsen et al.

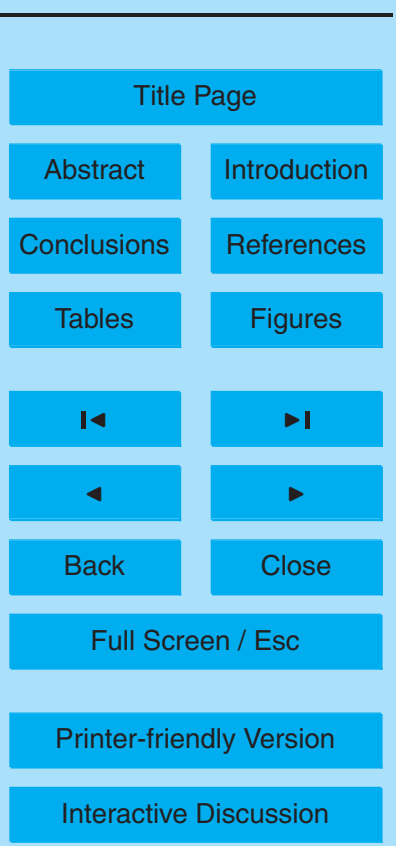




\section{ACPD}

8, 2163-2223, 2008

\section{Multi-model \\ assessment of ozone \\ pollution indices}

K. Ellingsen et al.

Table 2. Specifications of the simulations.

\begin{tabular}{lllll}
\hline Run & Scenario & Meteorology & Emissions & Reference \\
\hline S1 & Y2000 & 2000 (CTMs)1995-2004 (GCMs) & 2000 IIASA & Cofala et al. (2005) \\
S2 & CLE & 2000 (CTMs)1995-2004 (GCMs) & 2030 IIASA CLE & Cofala et al. (2005) \\
S3 & MFR & 2000 (CTMs)1995-2004 (GCMs) & 2030 IIASA MFR & Cofala et al. (2005) \\
S4 & A2 & 2000 (CTMs)1995-2004 (GCMs) & 2030 SRES A2 & Nakicenovic et al. (2000) \\
S5 & CLE-2030c & 2025-2034 (GCMs) & 2030 IIASA CLE & Cofala et al. (2005) \\
\hline
\end{tabular}

Title Page

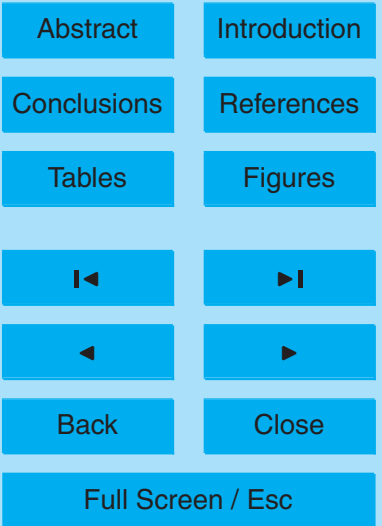

Printer-friendly Version

Interactive Discussion 
Table 3. Number of simulated years (excluding spin-up) performed by individual models. Also shown are the biogenic $\mathrm{C}_{5} \mathrm{H}_{8}$ and lightning NOx emissions, and the surface model layer thickness for each model.

\begin{tabular}{|c|c|c|c|c|c|c|c|c|}
\hline Model & S1 & S2 & S3 & S4 & S5 & $\begin{array}{l}\text { Vegetation } \\
\mathrm{C}_{5} \mathrm{H}_{8}(\mathrm{Tg} \mathrm{C} / \mathrm{yr})\end{array}$ & $\begin{array}{l}\text { Lightning } \\
\mathrm{NO}_{\mathrm{x}} \\
(\mathrm{Tg}(\mathrm{N}) / \mathrm{yr})\end{array}$ & $\begin{array}{l}\text { approximate } \\
\text { surface layer } \\
\text { thickness }(\mathrm{m})\end{array}$ \\
\hline CHASER_CTM & 1 & 1 & 1 & 1 & - & 400 & 5 & 65 \\
\hline CHASER_GCM & 9 & 9 & - & - & 9 & 400 & 5 & 65 \\
\hline FRSGC/UCI & 1 & 1 & 1 & 1 & - & 503 & 6.5 & 78 \\
\hline GEOS-CHEM & 1 & 1 & 1 & 1 & - & 402 & 3.7 & 200 \\
\hline GMI/CCM & 1 & 1 & 1 & 1 & - & 380 & 5 & 125 \\
\hline GMI/DAO & 1 & 1 & 1 & 1 & - & 380 & 5 & 101 \\
\hline GMI/GISS & 1 & 1 & 1 & 1 & - & 380 & 5 & 250 \\
\hline LLNL-IMPACT & 1 & 1 & 1 & 1 & - & 499 & 5 & 25 \\
\hline LMDz/INCA (CTM) & 1 & 1 & 1 & 1 & - & 402 & 5 & 70 \\
\hline MATCH-MPIC-ECMWF & 1 & 1 & 1 & 1 & - & 512 & 5 & 20 \\
\hline MATCH-MPIC-NCEP & 1 & 1 & 1 & 1 & - & 512 & 5 & 80 \\
\hline MOZ2-GFDL & 2 & 2 & 2 & 2 & - & 509 & 6.0 & 72 \\
\hline MOZART4 (NCAR) & 2 & 2 & 2 & 2 & 2 & 493 & 5 & 105 \\
\hline MOZECH & 5 & 5 & - & - & 5 & 516 & 8 & 60 \\
\hline p-TOMCAT & 1 & 1 & 1 & 1 & - & 220 & 3.9 & 65 \\
\hline TM4 & 1 & 1 & 1 & 1 & - & 631 & 7 & 50 \\
\hline TM5 & 1 & 1 & - & - & - & 400 & 5 & 50 \\
\hline UIO-CTM2 & 1 & 1 & 1 & 1 & - & 220 & 5 & 16 \\
\hline
\end{tabular}

\section{8, 2163-2223, 2008}

\section{Multi-model}

assessment of ozone pollution indices

K. Ellingsen et al.

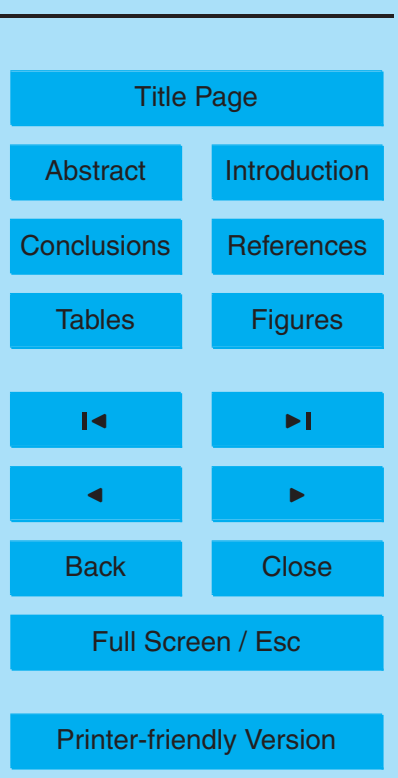

Interactive Discussion 


\section{ACPD}

8, 2163-2223, 2008

Table 4. Specified global annual totals for anthropogenic surface emissions and biomass burning emissions for each scenario.

\begin{tabular}{llllll}
\hline Species & $\mathrm{S} 1$ & $\mathrm{~S} 2$ & $\mathrm{~S} 3$ & $\mathrm{~S} 4$ & $\mathrm{~S} 5 \mathrm{c}$ \\
\hline $\mathrm{NO}_{\mathrm{x}}\left(\mathrm{Tg} \mathrm{NO} \mathrm{NO}_{2}\right)$ & 124.8 & 141.1 & 76.6 & 212.7 & 141.1 \\
$\mathrm{CO}(\mathrm{Tg})$ & 977 & 904.1 & 728.7 & 1268.2 & 904.1 \\
$\mathrm{NMVOC}(\mathrm{Tg})$ & 147.1 & 145.5 & 104.4 & 206.7 & 145.5 \\
$\mathrm{SO}_{2}(\mathrm{Tg})$ & 111.1 & 117.6 & 35.8 & 202.3 & 117.6 \\
$\mathrm{NH}_{3}(\mathrm{Tg})$ & 64.8 & 84.8 & 84.8 & 89.2 & 84.8 \\
$\mathrm{CH}_{4}(\mathrm{nmol} / \mathrm{mol})$ & 1760 & 2088 & 1760 & 2163 & 2012 \\
\hline
\end{tabular}

Title Page

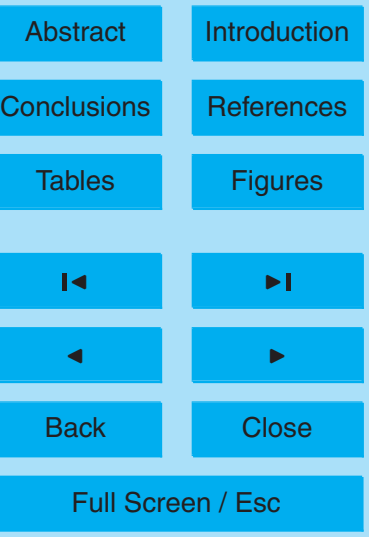

Printer-friendly Version

Interactive Discussion 


\section{ACPD}

8, 2163-2223, 2008

\section{Multi-model assessment of ozone pollution indices}

K. Ellingsen et al.

Table 5. Recommended natural emissions sources.

\begin{tabular}{lll}
\hline Species & Source & Annual emission \\
\hline $\mathrm{NO}_{x}(\operatorname{Tg~N})$ & Soils & 7 \\
& Lightning & 5 \\
$\mathrm{CO}(\mathrm{Tg})$ & Oceans/vegetation & 100 \\
$\mathrm{NMHC}(\operatorname{Tg~C})$ & Vegetation isoprene & 512 \\
& Vegetation terpenes & 260 \\
$\mathrm{SO}_{2}(\mathrm{Tg} \mathrm{S})$ & Volcanoes & 14.6 \\
$\mathrm{DMS}^{(\mathrm{Tg} \mathrm{S})}$ & Oceans/terrestrial biosphere & 20 \\
$\mathrm{NH}_{3}(\operatorname{Tg~N})$ & Oceans & 8.3 \\
& Soils & 2.4 \\
\hline
\end{tabular}

Title Page

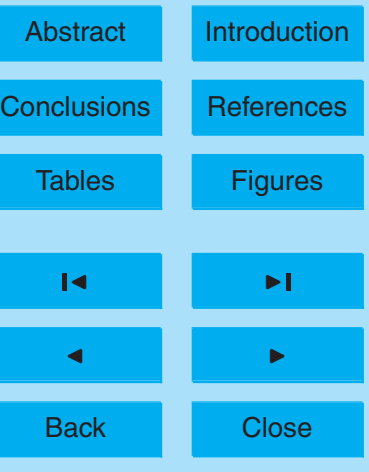

Full Screen / Esc

Printer-friendly Version

Interactive Discussion 


\section{ACPD}

8, 2163-2223, 2008

Table 6. Definitions of health indices used in the risk assessment.

\begin{tabular}{|c|c|c|}
\hline Index & Definition & Thresholds and effects \\
\hline $\begin{array}{l}\text { SOMO35 } \\
\text { (nmol/mol.days) }\end{array}$ & $\begin{array}{l}\sum_{i=1}^{n}\left[\max \_8 \mathrm{~h} \_ \text {mean }-35\right]_{i} \\
\text { for max_8h_mean }>35 \mathrm{nmol} / \mathrm{mol} \text {, where } \\
\text { max_8h_mean is the daily maximum } 8 \mathrm{~h} \text { aver- } \\
\text { age ozone vmr in } \mathrm{nmol} / \mathrm{mol}, n \text { is the number } \\
\text { of days in a year. }\end{array}$ & Threshold: No threshold defined \\
\hline $\begin{array}{l}\text { EU60 } \\
\text { (days) }\end{array}$ & $\begin{array}{l}\text { Number of days with maximum 8-h average } \\
\text { ozone vmr exceeding } 60 \mathrm{nmol} / \mathrm{mol}\end{array}$ & $\begin{array}{l}\text { Threshold: } 25 \text { days per year (during a } \\
\text { three years period) }\end{array}$ \\
\hline $\begin{array}{l}\text { USEPA80 } \\
\text { (days) }\end{array}$ & $\begin{array}{l}\text { Number of days with maximum } 8-\mathrm{h} \text { average } \\
\text { ozone vmr exceeding } 80 \mathrm{nmol} / \mathrm{mol} \text {. }\end{array}$ & $\begin{array}{l}\text { Threshold: the 3-year average of the } \\
\text { 4th highest daily maximum at each lo- } \\
\text { cation must not exceed } 80 \mathrm{nmol} / \mathrm{mol} \\
\text { (equivalent to a maximum value of } 3 \\
\text { days of exceedance per year) }\end{array}$ \\
\hline
\end{tabular}

\section{Multi-model assessment of ozone pollution indices}

K. Ellingsen et al.

Title Page

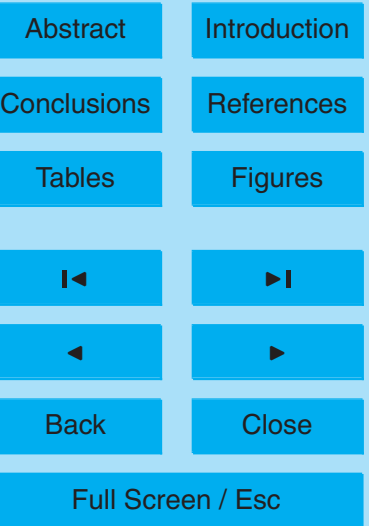

Printer-friendly Version

Interactive Discussion 
Table 7. Definitions of vegetation indices used in the risk assessment.

\begin{tabular}{|c|c|c|}
\hline Vegetation index & Definition & Receptor \\
\hline $\begin{array}{l}\text { AOT40 } \\
\text { (nmol/mol.hr) }\end{array}$ & $\begin{array}{l}\text { Sum of hourly daylight }\left(>50 \mathrm{~W} / \mathrm{m}^{2} \mathrm{PAR}\right) \text { ozone vol- } \\
\text { ume mixing ratio }(\mathrm{vmr}) \text { above } 40 \mathrm{nmol} / \mathrm{mol} \text { : } \\
\sum_{i=1}^{n}\left[\mathrm{CO}_{3}-40\right]_{i} \text { for } \mathrm{CO}_{3}>40 \mathrm{nmol} / \mathrm{mol} \\
\text { where } \mathrm{CO}_{3} \text { is the hourly ozone vmr in } \\
\mathrm{nmol} / \mathrm{mol} \text { and } \mathrm{n} \text { is the number of hours with } \\
\mathrm{CO}_{3}>40 \mathrm{nmol} / \mathrm{mol} \text {. }\end{array}$ & $\begin{array}{l}\text { Forest trees: } \\
\text { Accumulated over } 6 \text { consecutive months } \\
\text { of the growing season. } \\
\text { Threshold: } 5000 \mathrm{nmol} / \mathrm{mol} \mathrm{h} \\
\text { European Growing season: April to } \\
\text { September }\end{array}$ \\
\hline $\begin{array}{l}\text { SUM06 } \\
\text { (nmol/mol.hr) }\end{array}$ & $\begin{array}{l}\text { Sum of 24-hourly ozone vmr at or above } \\
60 \mathrm{nmol} / \mathrm{mol} \text { : } \\
\sum_{i=1}^{n}\left[\mathrm{CO}_{3}\right]_{i} \text { for } \mathrm{CO}_{3} \geq 60 \mathrm{nmol} / \mathrm{mol} \\
\text { where } \mathrm{CO}_{3} \text { is the hourly ozone } \mathrm{vmr} \text { in } \\
\mathrm{nmol} / \mathrm{mol} \text { and } n \text { is the number of hours with } \\
\mathrm{CO}_{3} \geq 60 \mathrm{nmol} / \mathrm{mol} \text {. }\end{array}$ & $\begin{array}{l}\text { Vegetation: } \\
\text { Accumulated over } 3 \text { consecutive months } \\
\text { of the growing season. Threshold: No } \\
\text { threshold defined }\end{array}$ \\
\hline $\begin{array}{l}\text { W126 } \\
\text { (nmol/mol h) }\end{array}$ & $\begin{array}{l}\text { Weighted sum of } 24 \text {-hourly ozone vmr: } \\
\sum_{i=1}^{n}\left[\mathrm{CO}_{3}\right] i * w i \\
\text { where } w_{i}=1 /\left(1+4403^{*} \exp \left(-0.126^{*} \mathrm{CO}_{3 i}\right)\right) \text { and } \\
\mathrm{CO}_{3 i} \text { is the hourly ozone } \mathrm{vmr} \text { in } \mathrm{nmol} / \mathrm{mol} \text {. }\end{array}$ & $\begin{array}{l}\text { Vegetation: } \\
\text { Accumulated over } 3 \text { consecutive months } \\
\text { of the growing season. Threshold: No } \\
\text { threshold defined }\end{array}$ \\
\hline
\end{tabular}

\section{8, 2163-2223, 2008}

\section{Multi-model assessment of ozone pollution indices}

\section{K. Ellingsen et al.}

\section{Title Page}

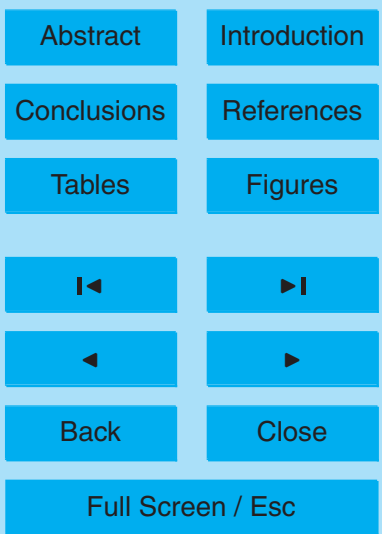

Printer-friendly Version

Interactive Discussion 
Table 8. The fourteen regions selected in this study.

\begin{tabular}{|c|c|c|c|c|}
\hline Region & Lat & Lon & \# of stations & References \\
\hline 1. Southwestern U.S. LA regions & $30 \mathrm{~N}-40 \mathrm{~N}$ & $125 \mathrm{~W}-110 \mathrm{~W}$ & 11 & CASTNET $^{1)}$ \\
\hline 2. Southeastern U.S. & $25 \mathrm{~N}-35 \mathrm{~N}$ & $90 \mathrm{~W}-80 \mathrm{~W}$ & 12 & CASTNET $^{1)}$ \\
\hline 3. Great Lakes & $40 N-50 N$ & $95 \mathrm{~W}-75 \mathrm{~W}$ & 13 & CASTNET $^{1)}$ \\
\hline 4. Latin America/Brazil & $25 S-15 S$ & $50 \mathrm{~W}-30 \mathrm{~W}$ & N.a. & N.a. \\
\hline 5. Central-West Africa & $5 \mathrm{~N}-15 \mathrm{~N}$ & $5 \mathrm{~W}-15 \mathrm{E}$ & 3 & Carmichael et al. (2003) \\
\hline 6. Southern Africa/High Field & $30 \mathrm{~S}-20 \mathrm{~S}$ & $20 E-35 E$ & 6 & Zunckel et al. (2004) \\
\hline 7. Central Mediterranean & $35 \mathrm{~N}-45 \mathrm{~N}$ & $5 E-30 E$ & 21 & EMEP, Airbase ${ }^{2)}$ \\
\hline 8. Central Europe & $48 N-54 N$ & $7 E-17 E$ & 101 & EMEP, Airbase ${ }^{2)}$ \\
\hline 9. Middle East & $30 \mathrm{~N}-40 \mathrm{~N}$ & $30 E-55 E$ & 1 & Carmichael et al. (2003) \\
\hline 10. North India + Nepal & $20 \mathrm{~N}-30 \mathrm{~N}$ & $70 \mathrm{E}-90 \mathrm{E}$ & 6 & $\begin{array}{l}\text { Naja et al. (2003) } \\
\text { Lal et al. (2000) } \\
\text { Carmichael et al. (2003) }\end{array}$ \\
\hline 11. Southern India & $10 N-20 N$ & $75 E-85 E$ & 4 & $\begin{array}{l}\text { Naja and Lal (2002) } \\
\text { Debaje et al. (2003) } \\
\text { Nair et al. (2002) } \\
\text { Carmichael et al. (2003) }\end{array}$ \\
\hline $\begin{array}{l}\text { 12. S.E. Asia } \\
\text { (Guangzhou Hongkong) }\end{array}$ & $20 \mathrm{~N}-35 \mathrm{~N}$ & $110 E-125 E$ & 3 & Carmichael et al. (2003) \\
\hline \multirow[t]{3}{*}{ 13. Northern China (Beijing)-Japan } & $35 N-45 N$ & $110 E-145 E$ & 8 & WMO-WDCGG ${ }^{3)}$ \\
\hline & & & & $\begin{array}{l}\text { Akimoto and Pochanart } \\
(2005)\end{array}$ \\
\hline & & & & Wang and Mauzerall (2004) \\
\hline 14. Australia & $25 S-40 S$ & $145 E-155 E$ & N.a. & $\begin{array}{l}\text { Carmichael et al. (2003) } \\
\text { N.a. }\end{array}$ \\
\hline
\end{tabular}

1) CASTNET: Clean Air Status and Trends Network (http://www.epa.gov/castnet/ozone.html)

2) EMEP: Co-operative programme for monitoring and evaluation of the long-range transmissions of air pollutants in Europe (http://www.nilu.no/projects/ccc/emepdata.html); Airbase: European Topic Centre on Air and Climate Change, Airbase dataset through AirView.

3) WMO-WDCGG: WMO Global Atmosphere Watch (GAW) - World Data Centre for Greenhouse Gases (WDCGG) (http://gaw.kishou.go.jp/wdcgg.html).

\section{Multi-model \\ assessment of ozone pollution indices}

K. Ellingsen et al.

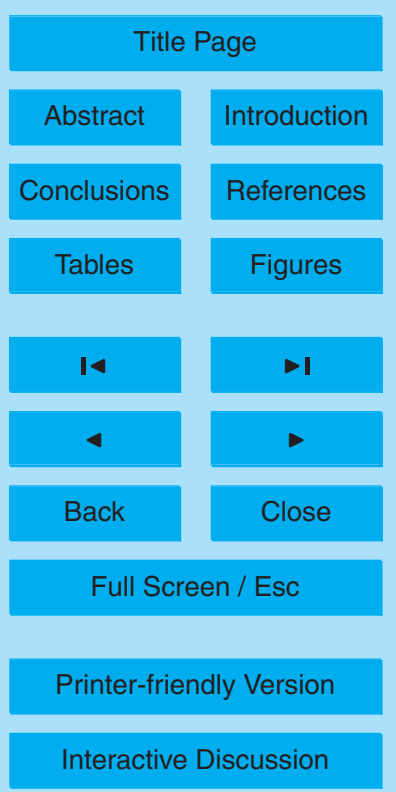



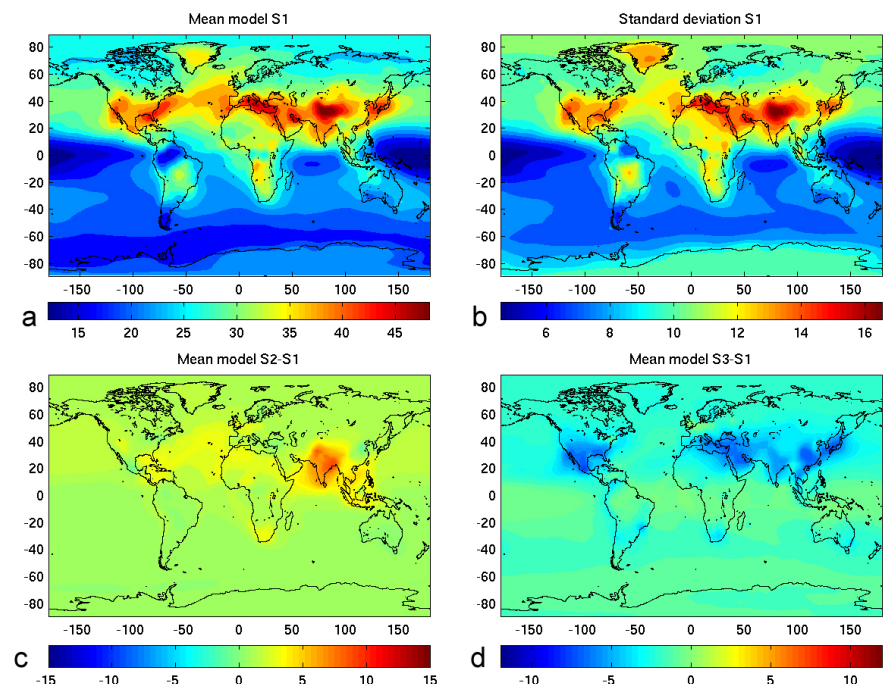

\section{ACPD}

8, 2163-2223, 2008

\section{Multi-model \\ assessment of ozone pollution indices}

K. Ellingsen et al.
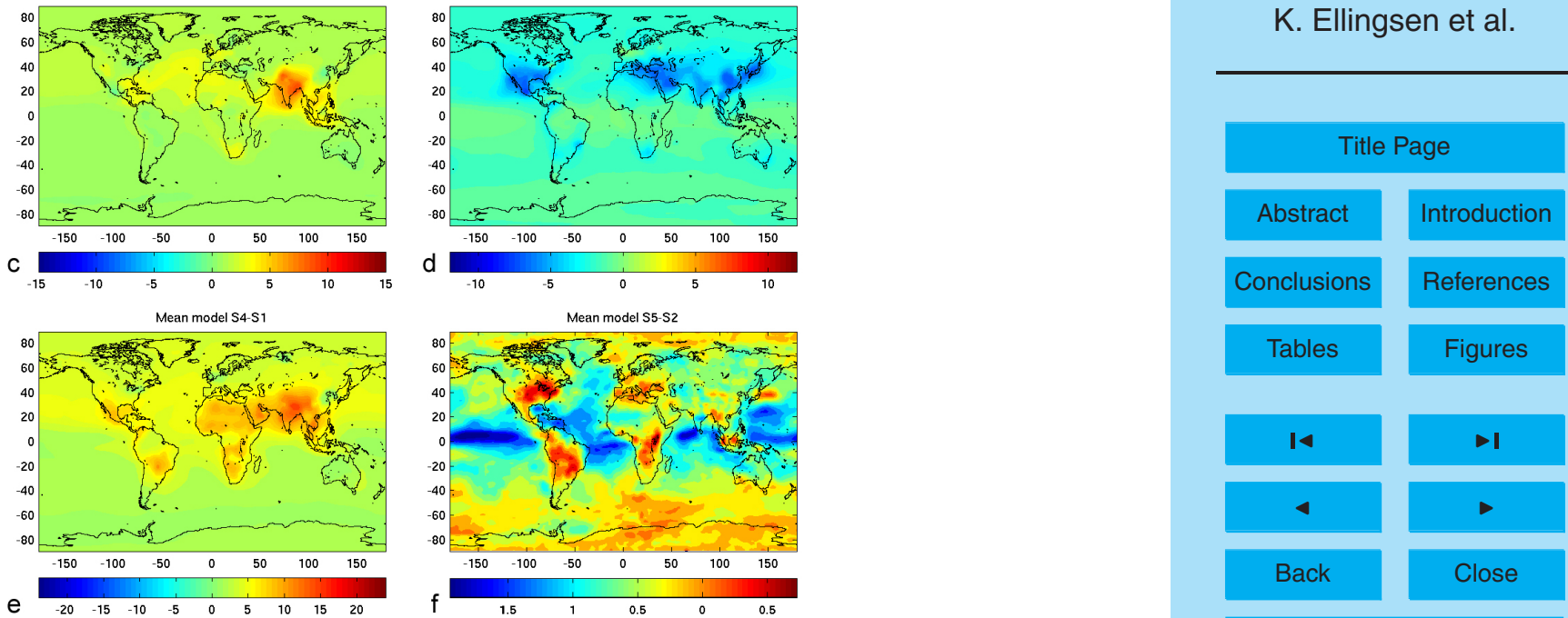

Full Screen / Esc

Fig. 1. Annual-mean surface ozone for the model ensemble: mean (a) and standard deviation (b) for S1 year 2000. Differences in surface ozone from 2000 to 2030, based on scenario CLE (c), MFR (d), and SRES A2 (e). (f) Change in annual mean surface ozone due to climate change. Ensemble differences are calculated as the average of the individual model simulation differences. Unit: nmol/mol.

Printer-friendly Version

Interactive Discussion 


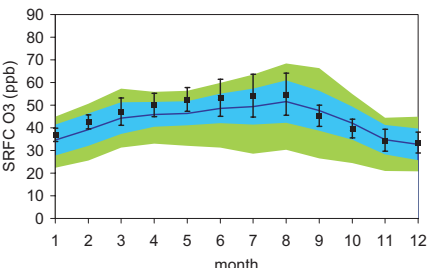

US Great Lakes
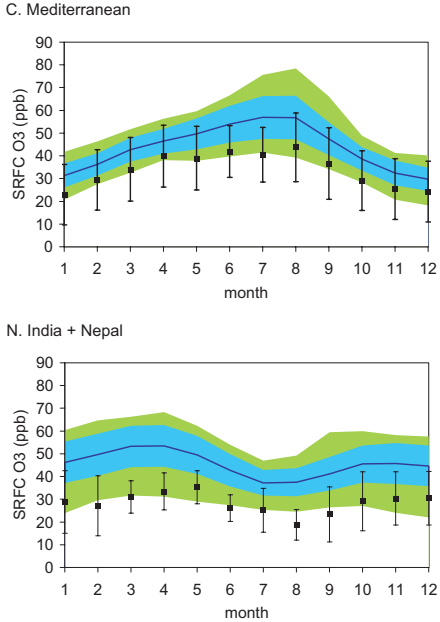

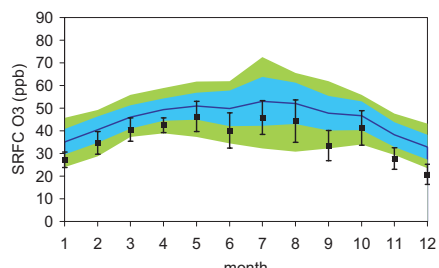

C. Europe
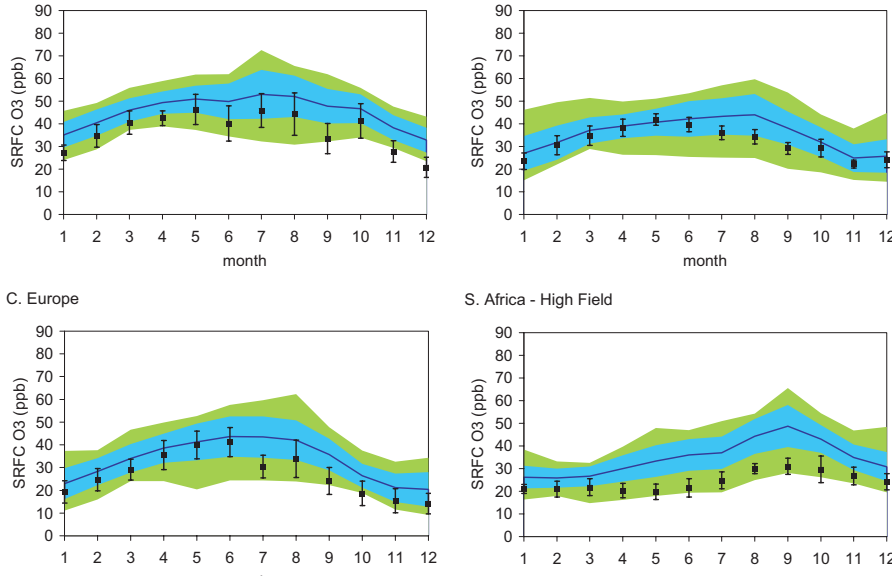

S. Africa - High Field

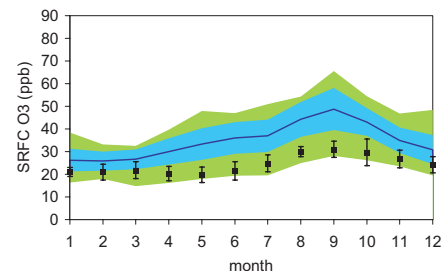

SE Asia
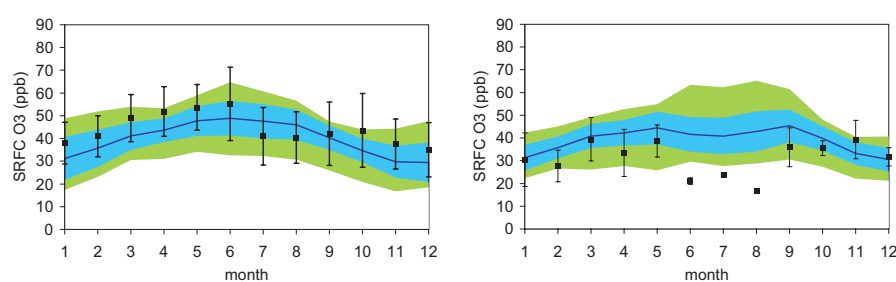

ACPD

8, 2163-2223, 2008

\section{Multi-model assessment of ozone pollution indices}

K. Ellingsen et al.

Fig. 2. Comparison of observed monthly mean, diurnal mean surface ozone levels (black squares) and the model ensemble mean (blue line). The observations are averages over several sites, and the black line represents the standard deviation. The blue shaded area gives the inter-model standard deviations of the model ensemble. The green area indicates the variation among the models, the upper line of the green shaded region gives the maxima of the model ensemble, and the lower line gives the model ensemble minima.

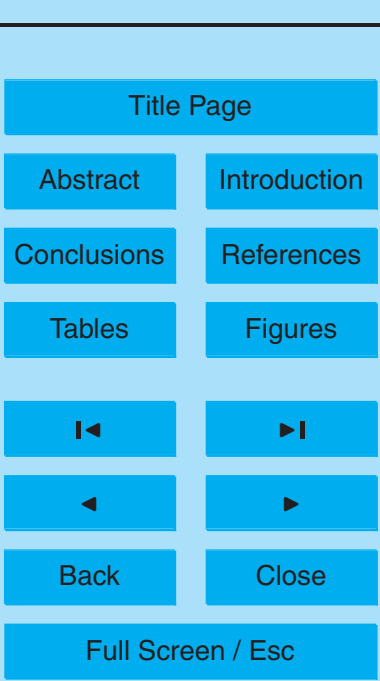

Printer-friendly Version

Interactive Discussion 


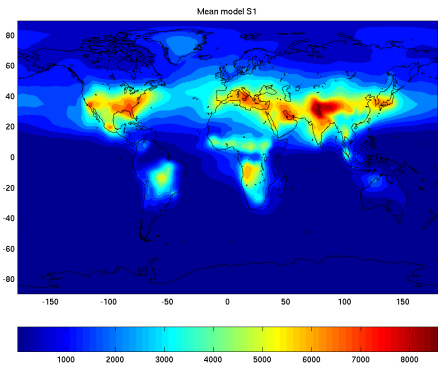

\section{ACPD}

8, 2163-2223, 2008
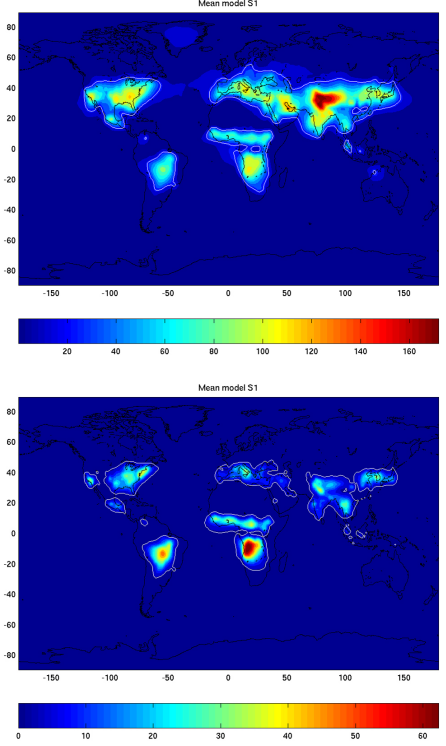

\section{Multi-model assessment of ozone pollution indices}

K. Ellingsen et al.

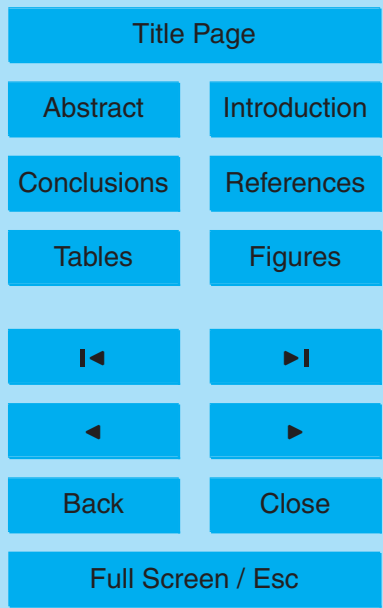

Fig. 3. Model ensemble mean health indices for year 2000 (S1). Top panel: SOMO35 (nmol/mol.days), middle panel: EU60 (days of exceedance), bottom panel: USEPA80 (days of exceedance). The white lines in the middle and bottom panels show the EU60 and USEPA80 thresholds for health risk, i.e. 25 days exceeding $60 \mathrm{nmol} / \mathrm{mol}$, and 3 days $80 \mathrm{nmol} / \mathrm{mol}$, respective. 


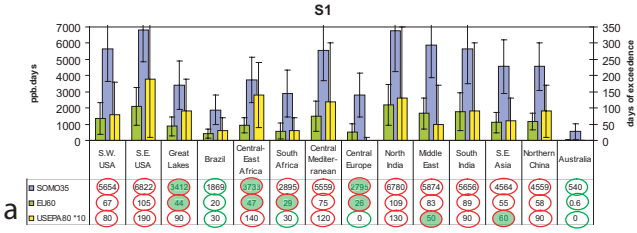

s2 - s1
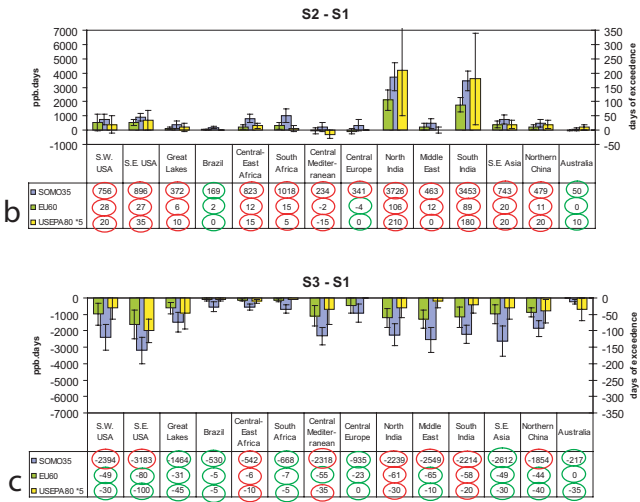

S4 - S1

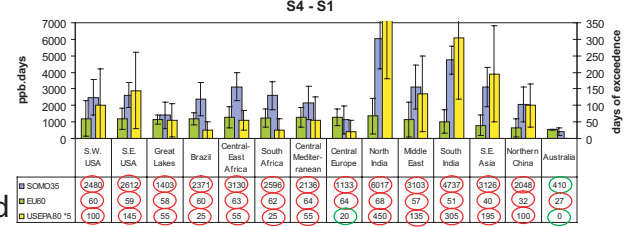

Fig. 4. (a) Model ensemble mean regional averages of health indices (blue bars: SOMO35, green bars: EU60, yellow bars: USEPA80). Panels (b), (c), and (d) show changes with respect to S1 for the scenarios S2, S3, and S4, respectively. Standard deviations are given by black lines. Regions with values exceeding the threshold for health risk are marked in red, and regions with values below recommended thresholds in green. Regions that would comply if air quality standards would be relaxed are indicated by red circles filled with green color.
ACPD

$8,2163-2223,2008$

\section{Multi-model \\ assessment of ozone pollution indices}

K. Ellingsen et al.

Title Page

Abstract

Introduction

Conclusions

References

Tables

Figures

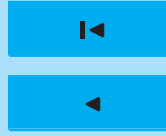

-

Back

Close

Full Screen / Esc

Printer-friendly Version

Interactive Discussion 


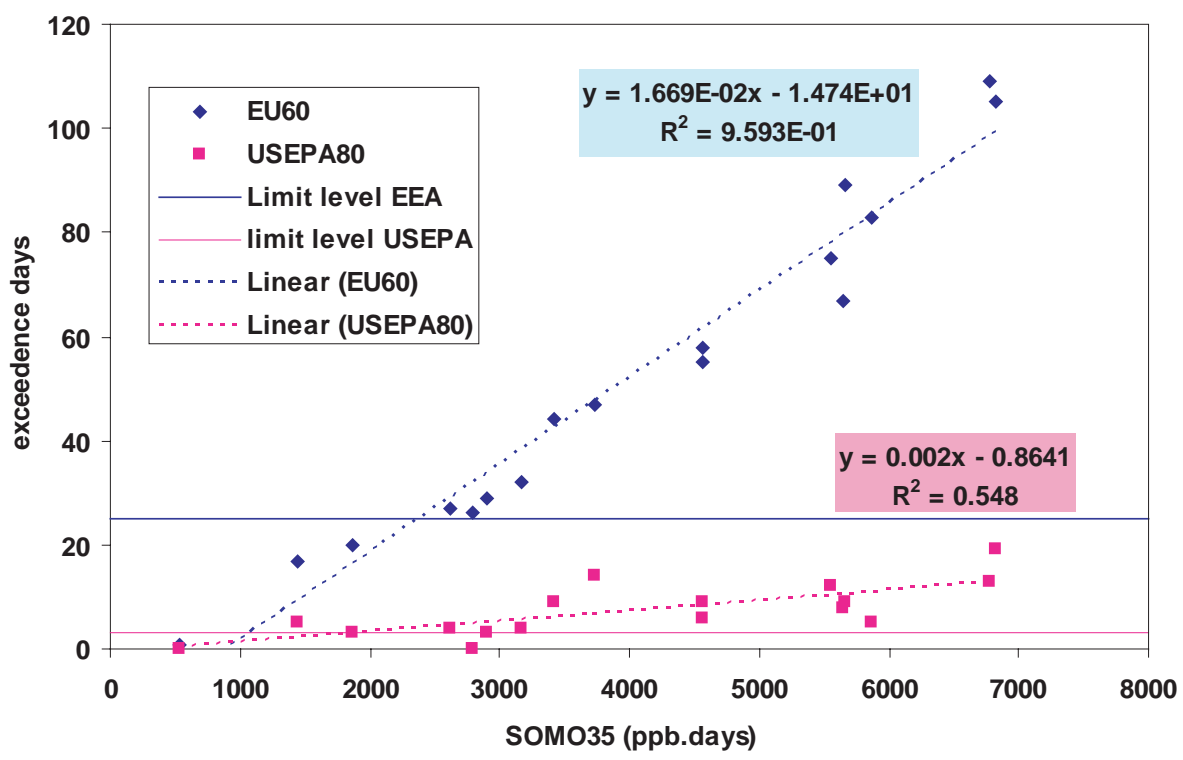

Fig. 5. Large scale correlation of SOMO35, and number of exceedance days for EU60 and USEPA80. Based on present day ozone in 14 world regions.
$8,2163-2223,2008$

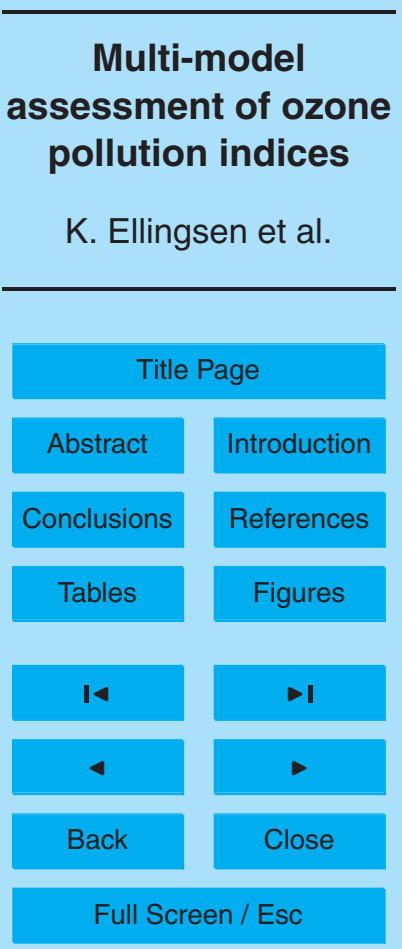

Printer-friendly Version

Interactive Discussion 

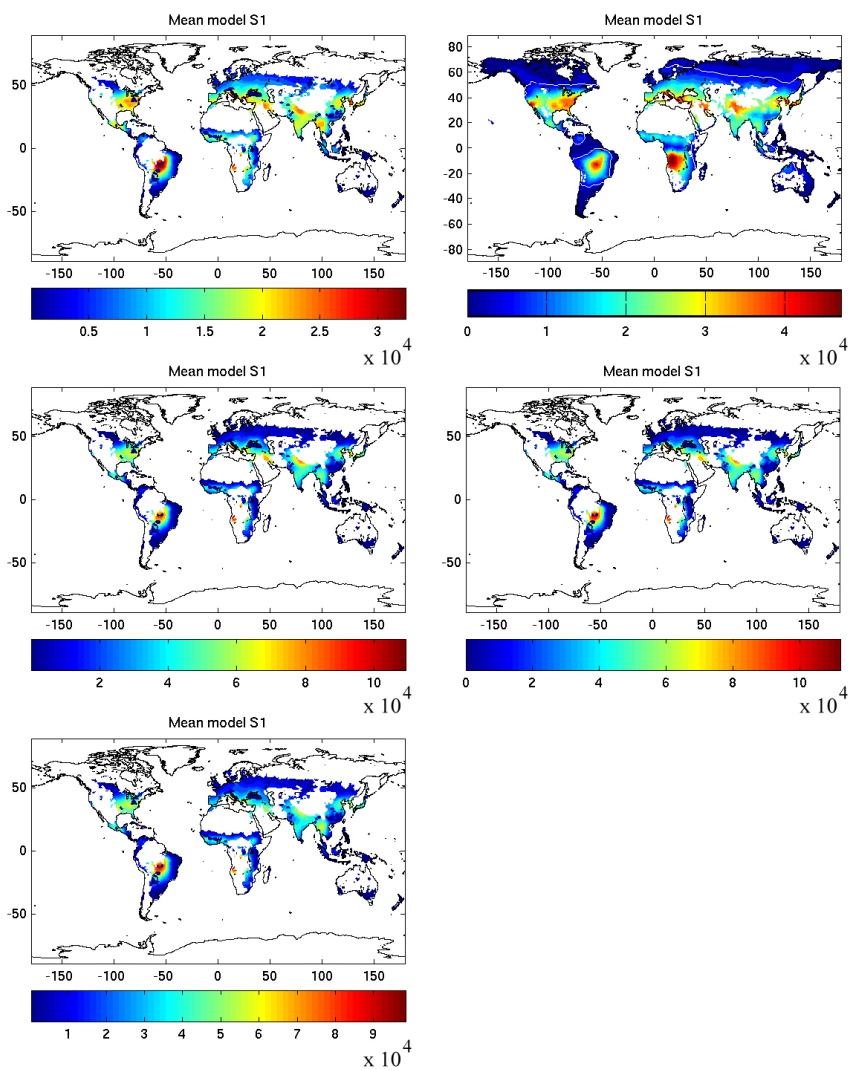

Fig. 6. Model ensemble mean vegetation indices for agricultural areas in $\mathrm{nmol} / \mathrm{mol} \mathrm{h}$. The growing season is in each gridbox defined as the three or six consecutive months with the highest index. Top left: AOT40 (3 months, daylight hours), top right: AOT40 (6 months, daylight hours), middle left: SUM06 (3 months growing season, $24 \mathrm{~h}$ ), middle right: SUM06 (3 months growing season, daylight hours), bottom left: W126 (3 months growing season, $24 \mathrm{~h}$ ).

\section{ACPD}

8, 2163-2223, 2008

\section{Multi-model assessment of ozone pollution indices}

K. Ellingsen et al.

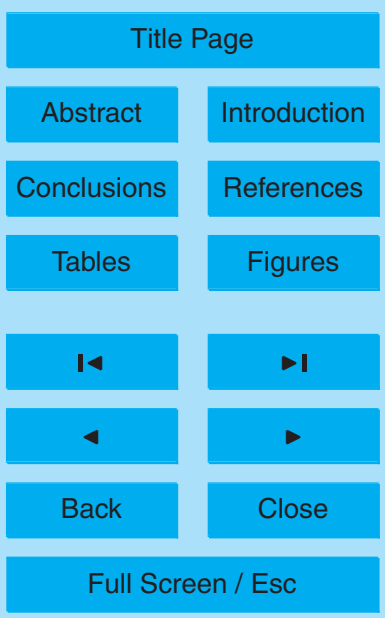

Printer-friendly Version

Interactive Discussion 


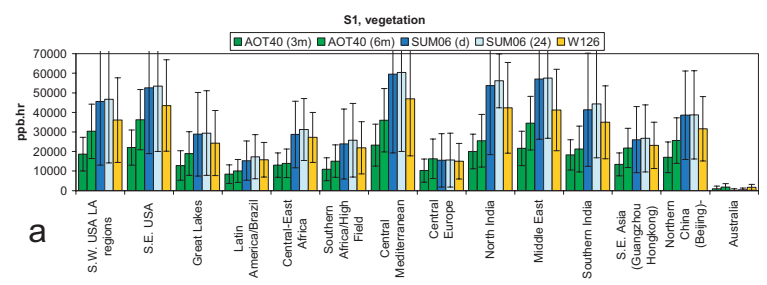

\section{ACPD}

8, 2163-2223, 2008

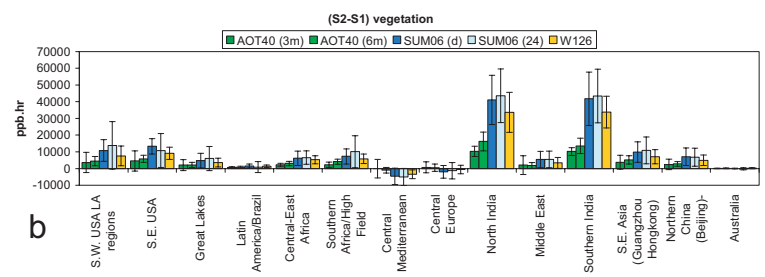

assessment of ozone pollution indices

K. Ellingsen et al.

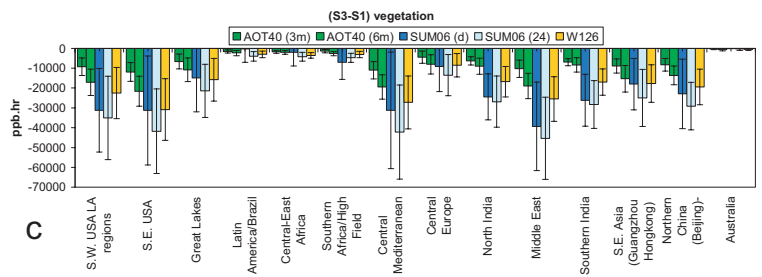

Title Page

Abstract

Introduction

Conclusions

References

Tables

Figures

14

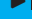

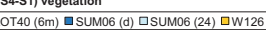

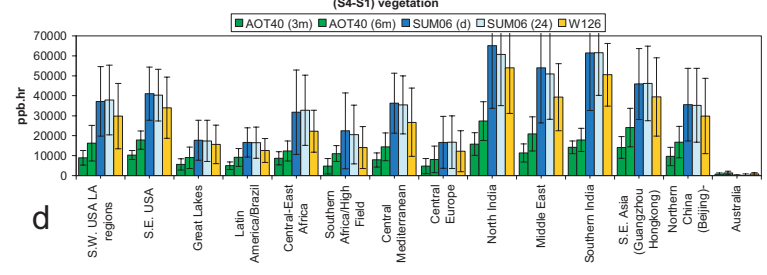

4

Back

Close

Full Screen / Esc

Printer-friendly Version

Interactive Discussion

Fig. 7. (a) Model ensemble mean regional averages (S1) of vegetation indices. Panels (b), (c), and (d) show changes with respect to S1 for scenarios S2, S3, and S4, respectively. Standard deviations are given by the black lines. 

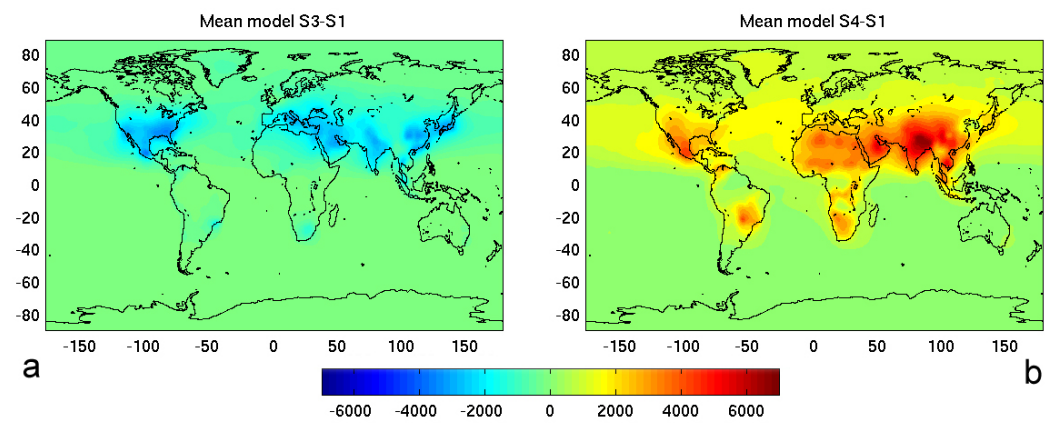

ACPD

8, 2163-2223, 2008

a

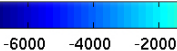

$\begin{array}{llll}0 & 2000 & 4000 & 6000\end{array}$

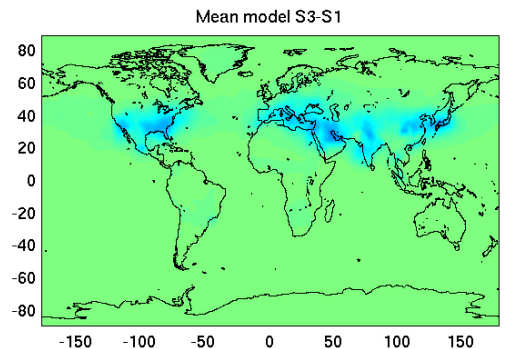

C

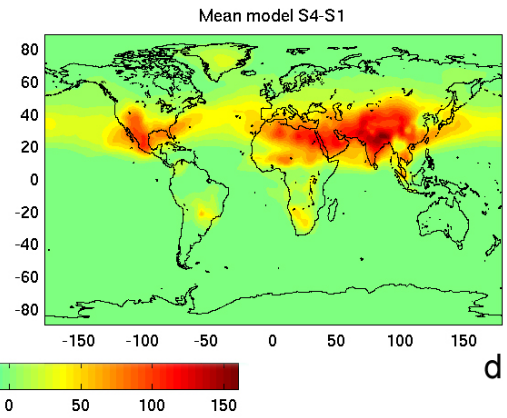

Title Page

Abstract

Introduction

Conclusions

References

Tables

Figures

14

Multi-model

assessment of ozone

pollution indices

K. Ellingsen et al.

4

Back

Full Screen / Esc

Printer-friendly Version

Interactive Discussion 

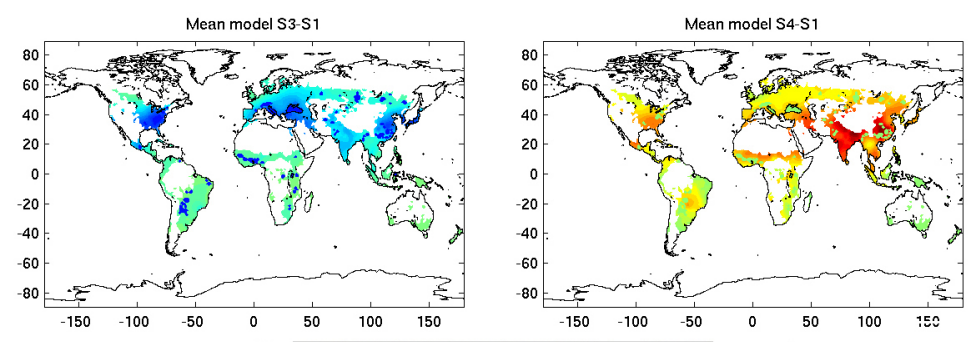

\section{ACPD}

8, 2163-2223, 2008

\section{Multi-model assessment of ozone pollution indices}

K. Ellingsen et al.

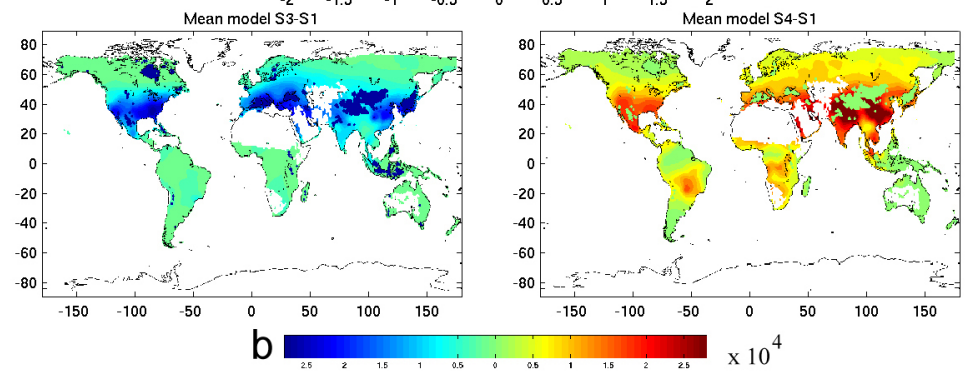

Title Page
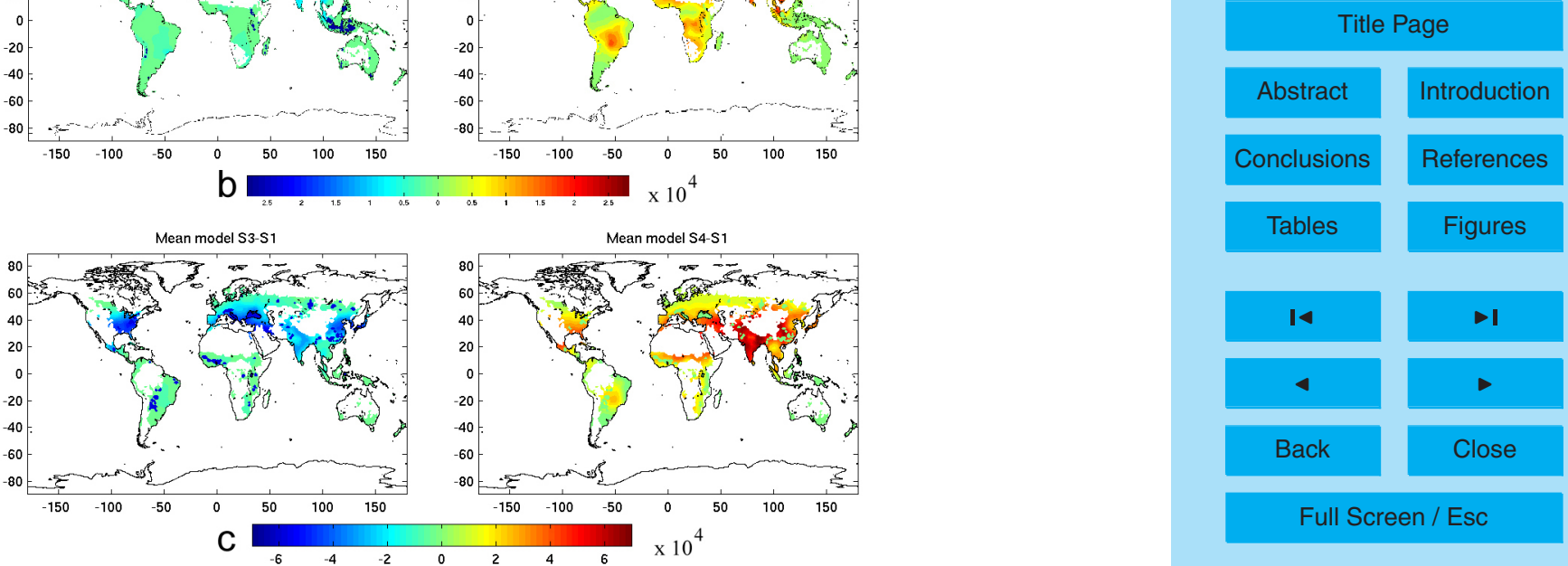

Full Screen / Esc

Fig. 9. Differences of ensemble mean vegetation indices $(\mathrm{nmol} / \mathrm{mol} \mathrm{h})$ Ensemble differences are calculated taking the average of the individual model simulation differences. (a) AOT40 (3 months, daylight hours), (b) AOT40 (6 months, daylight hours), (c) SUM06 (3 months growing season, daylight hours). 


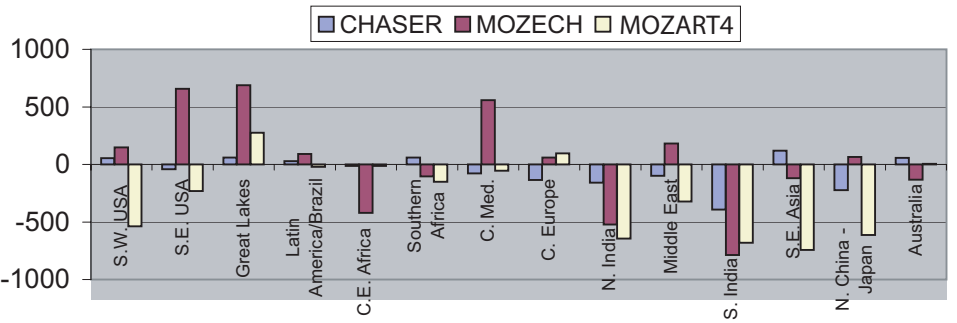

\section{ACPD}

$8,2163-2223,2008$

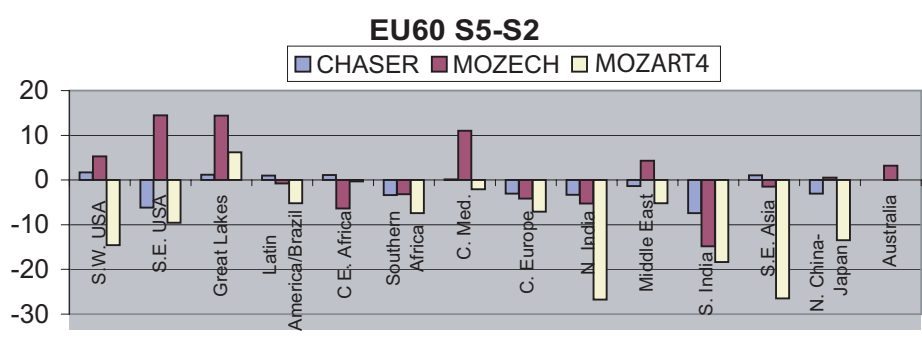

USEPA80 S5-S2

$\square$ CHASER $\square$ MOZECH $\square$ MOZART4

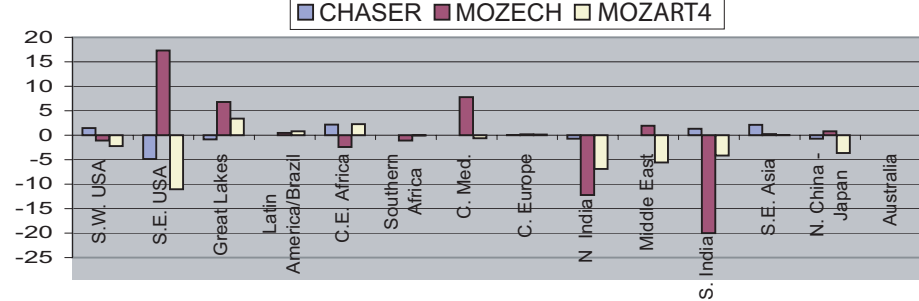

Fig. 10. Change in exceedance between $\mathrm{S} 5$ and $\mathrm{S} 2$, i.e. the isolated climate impact, for the CHASER, MOZECH, and MOZART4 models. Upper panel: SUMO35 ( $\mathrm{nmol} / \mathrm{mol}$ days), middle panel: EU60 (days of exceedance), bottom panel: USEPA80 (days of exceedance). Note that MOZECH used a different climate scenario for their runs.

\section{Multi-model}

assessment of ozone pollution indices

K. Ellingsen et al.

\section{Title Page}

Abstract

Introduction

Conclusions

References

Tables

Figures

14

$>1$

4

Back

Close

\section{Full Screen / Esc}

Printer-friendly Version

Interactive Discussion 